$$
\begin{aligned}
& \text { 龉 }
\end{aligned}
$$

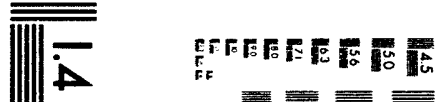

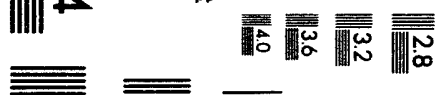

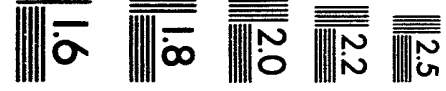



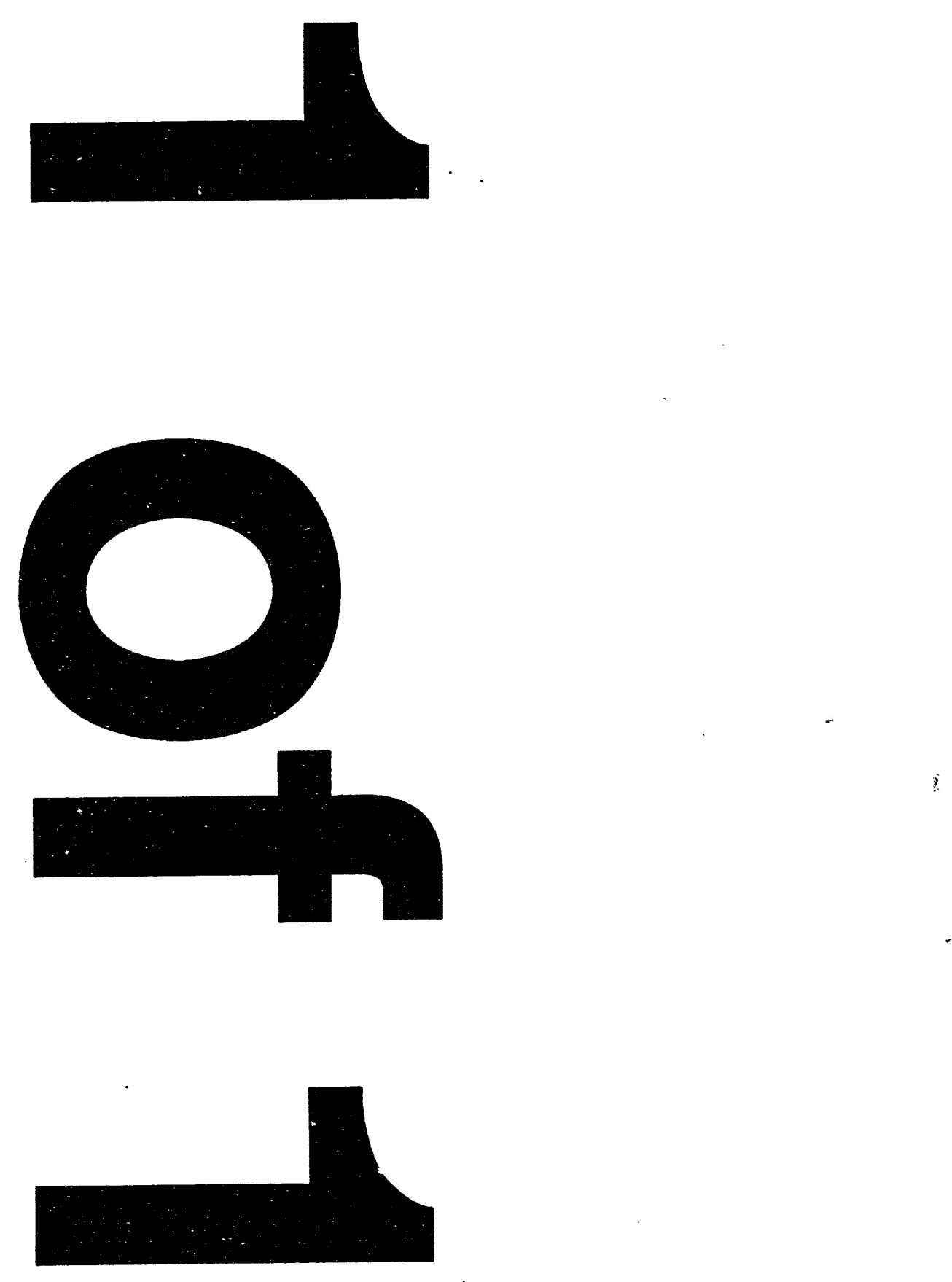


\title{
INDUSTRIAL- AND UTILITY-SCALE COAL-WATER FUEL DEMONSTRATION PROJECTS
}

\section{By}

\author{
V. Hathi \\ Science Applications International Corporation \\ P. O. Box 18288 \\ Pittsburgh, PA 15236
}

M. Ramezan

Burns \& Roe Services Corporation

P. O. Box 18288

Pittsburgh, PA 15236

and

\section{J. Winslow}

U. S. Department of Energy

Pittsburgh Energy Technology Center

P. O. Box 10940

Pittsburgh, PA 15236

January 1993 
NOTE

The authors intend to update this report periodically, therefore, we welcome any comments relating to projects that may have inadvertently been omitted, or information on projects that have been discussed that was unavailable, or perhaps overlooked in the literature. 
EXECUTIVE SUMMARY . . . . . . . . . . . . . . . . i i

1.0 INTRODUCTION . . . . . . . . . . . . . . . . . . . 1

1.1 PREVIOUS REVIEWS OF CWF COMBUSTION DEMONSTRATION PROJECTS . 2

2.0 CWF COMBUSTION DEMONSTRATION PROJECTS . . . . . . . . . . . 4

2.1 COMBUSTION DEMONSTRATIONS ON UNITS RATED OVER $100 \mathrm{MWe}$. . . 7

2.2 COMBUSTION DEMONSTRATIONS ON UNITS IN THE 15-100 MWe

2.3 COMBUSTION DEMONSTRATIONS ON UNITS IN

THE 1-15 MWe RANGE ............... 21

3.0 RESULTS FROM THE DEMONSTRATION PROJECTS . . . . . . . . . . . 31

4.0 SUMMARY AND CONCLUSIONS ......................... 40

5.0 REFERENCES ...................... 43

\section{TABLE}

\section{LIST OF TABLES}

1. Major Coal-Water Combustion Experience as of 1970 . . . . . . 50

2. Coal-Water Fuel Combustion Demonstration Projects . . . . . . . 51

\section{APPENDICES}

A. A Chronological List of Coal-Water Fuel Combustion

Demonstration Projects .................. A-1

B. Specifications of the Boiler Units Used for CWF Combustion

Demonstration Projects . . . . . . . . . . . . . . . B-1

C. Proximate Analyses of Fuels used for the CWF

Combustion Demonstration Projects ............. C-1

D. Feed Material Conditions and Burner/Atomizer Details on the

CWF Combustion Demonstration Projects ........... D-1

E. Expanded Publication List . . . . . . . . . . . . . . E-1 


\section{EXECUTIVE SUMMARY}

Since the 1973 oil embargo, the interest in coal-slurry fuels' has risen and declined in direct relation to the price of oil. Initially, interest focused oif coal-oil mixtures and, to a lesser extent, slurry preparation from a mixture of coal, oil, and water. However, in the late 1970s, it was realized that to take full advantage of the economics and to displace more oil, coal-water fuels (CWF) would be preferable. Also, as with these other slurry fuel forms, the desirable storage, transport, and handling characteristics associated with a liquid fuel are retained.

Coal-water slurries have been in use for over a hundred years. Initially, they were developed and used for transporting coal then dewatered prior to burning, but interest in the use of slurries as potential liquid fuels increased greatiy during periods of high oil prices. Prior to the late 1970s, coal-water slurries consisted simply of coal particles suspended in water. There was no attempt to control the particle size distribution or to utilize stabilizing additives. For this reason they could not be loaded to high solids content and were very unstable and settled rapidly. Especially for the latter reason, they would never have gained wide acceptance. In the late 1970s major advances were made in understanding the fundamental principles of coal-slurry technology. This led to the development of a vastly improved form of coal-water slurry wherein the coal particle size consist is carefully controlled, and surfactant and other additives are utilized to provide for CWFs with high coal loading, low viscosity, and longterm stability. These coal-water slurries are intended to be burned directly as a replacement for heavy oil.

Laboratory-, pilot-, and large-scale CWF combustion work has been performed primarily in Canada, China, Italy, Japan, Korea, Sweden, and the United States, and several projects are still active. Sponsors have included governments, utilities and their research arms, engine manufacturers, equipment suppliers, and other organizations in attempts to show that CWF is a viable alternative to premium fuels, both in cost and performance.

The objective of this report is to present brief summaries of past and current industrial- and utility-scale CWF demonstrations in order to determine what lessons can be learned from these important, highly visible projects directed toward the production of steam and electricity. Particular emphasis is placed on identifying the CWF characteristics; boiler type, geometry, size, and location; length of the combustion tests; and the results concerning system performance, including emissions.

The four appendices at the end of the report include details on the objectives of the projects, specifications of the boilers used to demonstrate combustion feasibility, proximate analyses of the fuels, and the burner and atomizer used

\footnotetext{
${ }^{1}$ In this report, the general term coal-slurry fuel is defined as coal solids combined with any of several media (such as oil, water, methanol) used as a carrier to make a liquid slurry fuel. If the carrier is specified, as in coalwater fuel (CWF), that term (or abbreviation) has been used.
} 
in the demonstration projects. To assure completeness, an expanded list of references on the demonstration projects has been included in Appendix $E$. 


\subsection{INTRODUCTION}

Since the 1973 oil embargo, interest in substituting coal-water fuels (CWFs) for oil has followed a direct trend with oil prices. This has been generally true for all countries involved in exploring the feasibility of using coal-based slurry fuels. Immediately after the embargo, the U.S. and many other countries focused on reducing oil consumption, which prompted organizations to begin development of alternative coal-based liquid fuels. In the period immediately following the embargo, coal-oil combinations were emphasized. Later, water was used to replace oil as the liquid medium, offering a further economic incentive.

Coal-water slurries have been in use for over a hundred years. Initially, they were developed and used for transporting coal then dewatered prior to burning, but interest in the use of coal-water slurries as potential liquid fuels increased greatly during periods of high oil prices. Prior to the late 1970s, CWFs consisted simply of coal particles suspended in water. There was no attempt to control the particle size distribution or to utilize stabilizing additives. For this reason they could not be loaded to high solids content and were very unstable and settled rapidly. Especially for the latter reason, they would never have gained wide acceptance. In the late 1970 s major advances were made in understanding the fundamental principles of coal-slurry technology. This led to the development of a vastly improved form of CWF wherein the coal particle size consist is carefully controlled, and surfactant and other additives are utilized to provide for CWFs with high coal loading, low viscosity, and long-term stability. These CWFs are intended to be burned directly as a replacement for heavy oil.

The first documented use of a coal-water slurry dates back to 1891 [1] when Wallace $C$. Andrews patented the concept and operatad a test facility for the transport of coal. However, there was no market-driven impetus to switch oilfired systems to coal-fired systems until the $0 i 1$ embargo of 1973. This change in the market condition forced many countries to investigate CWF's potential as an economically attractive option to oil in the mid-1970s. Since the late 1970s, however, the relative stability in the price of oil has created a diminished market incentive to develop CWF technology and use CWF on a large scale. Despite 
this situation, many laboratory-, pilot-, and large-scale projects in the U.S. and abroad were completed, some are continuing and plans for others are under way. This trend is clearly seen in the literature. Many countries have conducted large-scale demonstration projects to show transportation feasibility by various modes (truck, rail, barge, and sea), storage stability, equipment reliability for slurry utilization, and acceptable combustion of this fuel. These projects include ongoing development of CWF burners and atomizer systems for continuous long-term combustion of CWFs.

For CWF to be widely rommercialized, a market of sufficient size must be identified that will provide appropriate fuel economics. Most probably, this initial market will comprise utility and large industrial users that have decided to reduce or eliminate their use of oil in favor of a less expensive coal-based fuel such as CWF. Therefore, the objective of this report is not to describe all of the R\&D work that has been performed on CWF, but to focus on industrial- and utility-scale CWF demonstrations to determine what lessons can be learned from them. These demonstrations have been directed toward the production of steam and electricity and will form the major data base for developing the future CWF market. Particular emphasis is placed on identifying CWF characteristics; boiler type, geometry, size, and location; and length of combustion tests. The results concerning boiler and equipment performance and emissions are reported and, most importantly, analyzed to provide guidance for future projects.

\subsection{PREVIOUS REVIEWS OF CWF COMBUSTION DEMONSTRATION PROJECTS}

Several reviews of large-scale CWF combustion demonstration projects have been published. Prior to 1970, CWF combustion activities were limited mostly to Gemnany and the former USSR. The only trial project in the U.S. was an attempt by a group of companies (Consolidation Coal, Babcock \& Wilcox (B\&W), and Jersey Central Light and Power, and Texas Eastern Transmission Corporation) to develop coal-based transportable liquid fuel in 1961. A review of coal-slurry fuels is given in reference 2. The combustion work prior to 1970 was discussed by Marnell [3] and is listed in Table 1. Six projects were conducted in the USSR, and one each in the U.S. and Germany. Since then, however, the U.S. has continued CWF technology development and demonstration, and many other countries have conducted 
CWF demonstration projects, including Canada, China, Italy, Korea, Japan, Spain, Sweden, and the United Kingdom.

In an attempt to record the history and development of coal-liquid mixtures, Bienstock and Foo [4] published a report on the results of CWF firing in various boilers at the Pittsburgh Energy Technology Center. The report also includes discussion on the results from tests done elsewhere, particularly in Spain and the United Kingdom, for developing CWF. Unfortunately, very little information is available on the projects conducted in those two countries. Several years after the report of Bienstock and Foo, Faulkner [5] reviewed burner development tests and demonstration projects conducted in the U.S. and Canada in the period 1983-86. Also, Makansi [6], in an effort to highlight the availability of coalbased liquid fuel, reported on several successful CWF combustion demonstration projects during the period 1980-85.

In 1989, Miller [7] reported on many of the demonstration projects by country in a paper that included a discussion on the aspects of CWF utilization in industrial and utility boilers. At the 1990 Fifteenth International conference on Coal and Slurry Technologies, another paper by Miller et al. [8] discussed various demonstration projects within the United States on CWF combustion in industrial boilers.

In addition to providing updated reviews, an attempt has been made in this report to include comprehensive data from each major CWF demonstration to facilitate comparisons.' The narrative discussion of each project is presented in the order of boiler size ( 1 MWe to $600 \mathrm{MWe}$ ) used in the demonstration. The information is presented in Appendix $A$ in approximate chronological order by demonstration project and in Appendices $B, C$, and $D$ in the order of boiler size. The objectives of the demonstration projects are listed in Appendix $A$. The information on the boiler design specifications (Appendix $B$ ), fuels used (Appendix $C$ ), and burner and atomizer details (Appendix D) is provided in ranking order of boiler size used in the demonstration project. The majority of the

${ }^{1}$ Although there has been considerable work on CWF R\&D and pilot-scale combustion tests, the work has been considered beyond the scope of this report. 
information was drawn from the source indicated, while some information was obtained indirectly from the literature. To assure completenes, all related information not referenced in the text has been included in Appendix $E$. When applicable, additional information was obtained through correspondence with appropriate organizations.

A comprehensive survey of major CWF demonstration projects that have utilized boilers in the size range of approximately 1 MWe to 600 MWe is provided and broken down into three size categories for the convenience of readers who may want to focus on a specific category.

\subsection{CWF COMBUSTION DEMONSTRATION PROJECTS}

Table 2 lists, by boiler size, the demonstration projects that have been conducted in various countries. Because the boiler size was not reported for all projects, the rating in megawatt electric equivalent ${ }^{1}$ was calculated using the information provided in a related report [9].

The following briefly describes the involvement of the countries listed in Tables 1 and 2:

Canada: The Canadian government, through its Energy Mines and Research Center (EMR), conducted a joint program which included demonstration projects on Chatham Stations 1 and 2 in New Brunswick, and at a utility boiler of the Maritime Electric Company in Charlottetown, Prince Edward Island.

${ }^{1} T$ The megawatt electric equivalent was used as a common basis to classify CWF combustion demonstration projects since different projects raised heat for different purposes, e.g. electric power, space heating or other industrial use. It is realized that megawatt electric does not have any meaning for non-power generating systems. For nonpower generating systems, this report uses a factor of $10 \mathrm{million}$ Btu/hr $=1$ MWe. 
China: The China Association for Coal Processing and Utilization has directed commercial-scale tests of CWF combustion on the 20-ton $1 / \mathrm{hr}$ (5.5 MWe) and 60 -ton/hr (15 MWe) industrial boilers of the Beijing First Paper Mill. These demonstrations were conducted in cooperation with Zheijiang University and other organizations. Currently, Hua-Mei coalwater mixture Technology Center now organizes and coordinates CWF research and applications of CWF technology in China. The Center has 16 organizations (academic, government, and industry) affiliated with it.

Germany: This country is one of the few nations that attempted CWF demonstration projects in the 1960s (Table 1). No information on other large-scale demonstrations in Germany has been available since that time.

Italy: The Italian Generating Board (ENEL) is implementing government policy to develop CWF technology and has sponsored research and directed large demonstration projects in that country. Snamprogetti, which has built two CWF production plants in Italy, has actively participated in this national effort. These italian organizations combined their efforts to conduct an exploratory demonstration project at Santa Barbara in Italy. The U.S. Department of Energy (DOE) has participated in these projects and some of the test results obtained on the 35-MWe Santa Gilla generating station demonstration were discussed in the Fifteenth International Conference on Coal and Slurry Technologies held in 1990.

Japan: Since the exploratory combustion test of a U.S.-made CWF on a large scale multiple-tube furnace [10], the Fuyo Group ${ }^{2}$ of companies has completed demonstration projects on boilers of at least two sizes. These projects have included a full-scale burner demonstration, a long-term test of CWF combustion at Unit No. 4 ( 75 MWe), and a test of partial firing of CWF (with other fuels such as coal and oil) has been conducted at Unit No. 8 (600 MWe) since 1988. According to the Fuyo Group, these

'Throughout this report, ton refers to metric ton $(2,205 \mathrm{lb})$.

${ }^{2}$ Ref. 10 discussed Fuyo Group as consisting of Marubeni Corp., Nippon Kokkan K.K., Nippon $0 i l$ and Fats Co., and Hitachi Ltd. 
projects confirmed that retrofitting these units to fire CWF is possible without significant impact on combustion performance, unit operation, and emissions. At the Sixteenth International Conference on Coal \& Slurry Technologies, the results of a CWF combustion demonstration project funded by the Japan Ministry of International trade and Industry were presented [11]. This project used a 110-ton/hr steam (30.3 MWe) unit located at the Hokkaido Refinery of Idemitsu Kosan Co.

Sweden: The CWF combustion projects in Sweden started in the early 1980s. The first published demonstration projects were at the Sundbyberg Municipal District Heating unit and at the Utility of Lund. After successful completion of the demonstration project at Lund, the Swedish firm Fluidcarbon entered into three commercial contracts to fire CWF in boilers that supplied heat for industrial uses.

United Kingdom: The Central Electricity Generating Board, NEI, Babcock Power, and Foster Wheeler have reported on CWF combustion research and development. Anjum and Winnard [12] described Foster Wheeler's plans to use CWF in a 10-MW thermal (3.4 MWe) package boiler, originally designed for oil. They provided details of the design considerations, equipment, material specifications, boiler modifications, fuel/ash handling, and commissioning of the boiler for a demonstration project in a paper presented in 1987 [12]. Further details on this project, such as the duration of combustion and project success, are not available; hence, this project is not included in various lists provided in this report.

United States: A group of companies conducted a demonstration project at the Jersey City Power and Light Company's cyclone boiler at Perth Amboy, NJ, prior to the 1973 oil embargo (Table 1), and other projects were conducted after the oil embargo. The sponsors of the projects within the U.S. have included the U.S. Government through its Department of Energy and Environmental Protection Agency (EPA), the Electric Power Research Institute (EPRI), and many companies acting independently. EPA, EPRI, and other organizations conducted a demonstration project at the DuPont Facility in Memphis, TN. EPRI also sponsored development and 
demonstration of 100-million Btu/hr (10 MWe) burner systems developed by $B \& W$ and Asea Brown Boveri Combustion Engineering (ABB/CE). B\&W, Boston Edison, South Carolina Electric \& Gas Co., and Valleydale Packers, Inc. conducted projects on their own initiative.

Under funding from the DOE and the Commonwealth of Pennsylvania, the Pennsylvania State University is conducting a project to retrofit a 15,000-1b (6.80 tons) steam/hr (1.8 MWe) oil-fired boiler. Testing on this unit started in 1992.

USSR: Sufficient CWF development and utilization (Table 1) was achieved in the USSR in the 1960s to make the concept attractive to that country. In cooperation with Italian companies, a 161-mile (260-kilometer) coal slurry pipeline was recently completed and the combustion results associated with this project are expected soon. A preliminary status of the Belovo-Novosibirsk pipeline project was presented at the sixteenth International Conference on Coal and Slurry Technologies held in 1991 [13].

This report discusses all demonstration projects within the 1 MWe-600 MWe scale that were identified in the literature search. However, complete information on many projects was not readily available. Efforts are continuing to collect new technical data and details on the projects listed in Table 2.

The following provides a brief summary of each project. For convenience, the projects are separated by unit size as large (100 MWe and over), medium (15-100 MWe), and small (1-15 MWe).

\subsection{DEMONSTRATION PROJECTS ON UNITS RATED OVER 100 MWE}

Three demonstration projects conducted with boilers rated over 100 MWe, in which the CWF provided partial heat input to generate the designed steam load, are the CWF demonstration at the Nakoso \#8 boiler in Japan, Boston Edison's 135-MWe Mystic \#4 station project, and the 125-MWe exploratory demonstration at Santa Barbara, Italy. 


\subsubsection{CWF Demonstration at the Nakoso \#8 Boiler $(600$ MWe) $[14,15]$}

In Japan, the Fuyo Group's attempts to establish CWF as a viable fuel have resulted in successful large-scale burner endurance tests and partial continuous CWF firing on the Nakoso \#8 (600 MWe) boiler since 1988.

The unit at the Nakoso power station \#8, the largest unit used anywhere in the world to demonstrate CWF combustion feasibility, is a tangentially fired supercritical sliding-pressure boiler manufactured by Mitsubishi Heavy Industries (MHI). This boiler, designed for co-firing $50 \%$ coal with $50 \%$ oil, has been in operation since 1983. The maximum continuous rating (MCR) for this boiler is 1,940 tons $/ \mathrm{hr}(4,277,700 \mathrm{lb} / \mathrm{hr})$ at $255 \mathrm{~kg} / \mathrm{cm}^{2}(3626 \mathrm{psi})$ and $543 / 568^{\circ} \mathrm{C}$ $\left(1009 / 1054^{\circ} \mathrm{F}\right)$. During testing with a large burner system of 11 -ton/hr $(200$ $\mathrm{MBtu} / \mathrm{hr}$ ) capacity [14], the flame stability and firing conditions were good for operation within the 600-MWe to 300-MWe load range. In this load range, about $50 \%$ burner turndown was possible. Burner tips protected by silicon carbide had longer life expectancy than tips protected by tungsten carbide $(2000 \mathrm{hr}$ versus $1500 \mathrm{hr}$ ). CWFs made from six different coals were used for the demonstration of the burner system. The atomizer for these burner tests was an intermediate mixing type that was atomized by steam. The Mitsubishi MARC burner system was used for this project and performed well for over 2200 hours of testing.

Both gaseous emissions and unburned carbon levels in the fly ash that resulted from firing CWF were comparable to the levels obtained when using oil or pulverized coal. In other words, use of CWF did not negatively impact emissions or the overall performance of the unit. On the basis of the positive results with this burner system on a unit of this size, a decision was made to continue partial utilization of CWF in the boiler beginning in early 1988 for one of eight stages (oil at five stages and pulverized coal at two) on this 600-MWe unit. Over 70,000 tons (154 million pounds) of CWF was used during the 1988-89 operation. The results of pver a year's testing showed that the combustion performance, emissions, and unit operability were acceptable. The Fuyo Group concluded that CWF technology was ready for long-term continuous use [14]. 


\subsubsection{Boston Edison's 135 MWe Mystic \#4 Station $[5,7,16]$}

To examine the feasibility of converting its Mystic Station Unit 4 to fire CWF, Boston Edison conducted a ten-ciay test burn in November 1984 . Unit 4 is a tangentially fired $A B B / C E$ designed boiler rated at $135 \mathrm{MWe}$, which can produce $935,000 \mathrm{lb}(424$ tons $)$ of steam $\left[1000^{\circ} \mathrm{F}\left(537^{\circ} \mathrm{C}\right), 1970 \mathrm{psig}\left(138 \mathrm{~kg} / \mathrm{cm}^{2}\right)\right]$ per hour. In addition to CWF combustion, fuel stability and transportation were also studied. Barges dedicated to CWF transportation for a 750-mile (1207-kilometer) journey on river, canal, and sea were used to avoid fuel contamination and cleaning problems associated with the use of oil barges.

Approximately $6 \%$ of the heat input was provided by firing CWF (co-fired with oil) through a separate burner. The CWF for this test burn was supplied by Atlantic Research Corporation and was made from Kopperston Coal [2.8\% ash and dry heating value of $15,000 \mathrm{Btu} / \mathrm{lb}(34.89 \mathrm{MJ} / \mathrm{kg})]$. The CWF had a $30 \%$ water content and a heating value of $10,849 \mathrm{Btu} / 1 \mathrm{~b}(25.23 \mathrm{MJ} / \mathrm{kg})$.

Two 35-MBtu/hr (3.5 MWe) Coen atomizers were used in opposite corners and replaced 2 of 24 oil guns. The atomizers had borofuse coatings for wear protection and used air for the atomizing media. Since only 6\% of the total heat was generated from CWF combustion, little performance data were reported in the literature. However, the demonstration did confirm the ease of CWF handling and the feasibility of partial CWF combustion in a 135-MWe oil-fired unit.

\subsubsection{MWe Exploratory Demonstration Project at Santa Barbara, Italy [17]}

A series of experimental tests using three CWFs was conducted to explore the effect of burner geometry, CWF quality and concentration, slurry firing conditions such as slurry preheating, and type of atomizing media on flame stability and ignition. The tests were performed using one of the two 125-MWe boiler units at the Santa Barbara Station in Italy, and was one of the early projects on CWF undertaken after the oil embargo in the 1970 s. 
The unit, designed and constructed by Deutsc e Babcock in 1958, had a dodecagonal cross-section. Only one burner was operated with CWF, while the remaining eight burners were fired with oil. Two burner types (original B\&W and improved design) were used for the tests. The unit was operated at a maximum 60\% 10ad capacity. Three CWFs were fired using a Y-mixing atomizer. The three CWFs were prepared from coals of different composition and various solid concentrations. The volatile matter contents of the three parent coals used in the CWFs were 32,23 , and $17 \%$, respectively, and the solids content of the CWFs ranged from 68-72 wt\%. CWF with the lower (68\%) solids content produced better flames than CWF containing higher amounts of solids. The concentrated slurry also presented problems in maintaining ignition stability on low loads. The use of air as an atomizing fluid produced better ignition than steam.

Up to an 18-MW thermal load, the CWF flames could be maintained even under difficult operating conditions without any support fuel, i.e., at low atomizing $\operatorname{air}\left(25^{\circ} \mathrm{C}\right.$ or $\left.77^{\circ} \mathrm{F}\right), \quad \mathrm{CWF}\left(20^{\circ} \mathrm{C}\right.$ or $\left.68^{\circ} \mathrm{F}\right)$, and combustion air $\left(180^{\circ} \mathrm{C}\right.$ or $\left.356^{\circ} \mathrm{F}\right)$ temperatures.

\subsection{DEMONSTRATION PROJECTS ON UNITS IN THE 15-100 MWE RANGE}

Ten demonstration projects were conducted with units in this size range. Two projects used units in the 75 MWe range; four projects, including an early 1960 s demonstration in the U.S., were conducted on units of 30-60 MWe size; and four other projects utilized 15-30 MWe size units.

\subsubsection{South Carolina Electric and Gas Co.'s (75 MWe) Unit $[5,18]$}

In mid-1984, South Carolina Electric and Gas Company (SCE\&G), in cooperation with U.S. Fluidcarbon, Inc., conducted a CWF firing demonstration. The boiler selected for the demonstration was a coal-burning unit located at the utility's Urquhart Station on Beech Island, South Carolina. The unit was one of three 75MWe, ABB/CE tangentially fired units. A Coen internal-mix oil atomizer using air as the atomizing medium was inserted into a guide tube between the top and middle rows of burners. The size of the atomizer was reduced somewhat to fit an 
existing pipe to the shield. This constituted the only major modification to the otherwise coal-fired unit. The atomizer was rated at 30 million ( $3 \mathrm{MWe}$ ). CWF combustion provided $10-30 \%$ of the total heat required [5].

Slurries made from three different coals were used in this demonstration. The solids content of the slurries ranged from $66-69 \%$ and their average heat values were $9,357 \mathrm{Btu} / \mathrm{lb}(21.764 \mathrm{MJ} / \mathrm{kg})$. The sulfur content of the parent coals used for CWF ranged from 0.9 to $1.3 \%$ on an as-received basis. Approximately 900 tons (2 million pounds) of slurry was fired during this project.

The performance of the electrostatic precipitator was monitored during the program; no significant differences were noted when operating with coal or with CWF, although the opacity of the flue gas was lower when firing the CWF. This result, however, was considered to be inconclusive, and further work was recommended.

\subsubsection{Nakoso Power Station, Unit \#4, Japan (75 MWe) [19]}

Prior to projects on the larger 600-MWe Nakoso \#8 unit, the Fuyo group of companies completed demonstration projects using the Nakoso \#4 unit rated at 75 MWe. This unit was designed originally for burning a low-grade Japanese coal. Designed by Mitsubishi and put into service in 1961, the unit is a naturalcirculation, balanced-draft, radiant-reheat, corner-fired boiler producing $573,300 \mathrm{lb} / \mathrm{hr}$ steam $\left(260 \mathrm{tons} / \mathrm{hr}\right.$ ) at $1706 \mathrm{psi}\left(120 \mathrm{~kg} / \mathrm{cm}^{2}\right)$ and $1005^{\circ} \mathrm{F}\left(541^{\circ} \mathrm{C}\right)$. The boiler was fitted with 16 Mitsubishi MARC CWF burners, each rated at 60 million Btu/hr (6 MWe) at $7056 \mathrm{lb} / \mathrm{hr}(3.2 \mathrm{ton} / \mathrm{hr})$ fuel firing rate.

The CWF for this demonstration was prepared by two processes: (1) Mitsubishi's low-concentration wet grinding process, which includes a dewatering step through a vacuum filter to control the final solids content of the CWF; and (2) a highconcentration wet grinding process developed by Hitachi. Each process plant was capable of producing 15 tons/hr of slurry fuel, at a nominal coal loading of $70 \%$. 
Five CWFs were made from different coals. A total of 2060 hours was logged to prepare CWF by the low-concentration wet grinding process $(29,800$ tons or $65,709,000 \mathrm{lb})$. During 1850 hours of CWF preparation by the high-concentration wet grinding process, 28,000 tons of CWF was prepared [19].

The boiler could be operated at the design steam conditions on any of the five slurries. The operations were very stable, just as for oil firing. The exhaust gas emissions and unburned carbon in fly ash met all the environmental specifications. For the domestic coal, the $\mathrm{NO}_{\mathrm{x}}$ level was $197 \mathrm{ppm}$ (corrected to $6 \% \mathrm{O}_{2}$ ) and the unburned carbon in the fly ash was $0.7 \%$.

The performance report indicated that all the test parameters were met on this demonstration, which included a 3:1 burner turndown and carbon conversion in excess of $98.7 \%$ for slurries from all five coals. The report claimed that the technology was ready for utility boiler application.

\subsubsection{Werner Station of the Jersey Central Power and Light Co. (60 MWe)}

A full-scale demonstration was performed in 1961 at the Werner Station of the Jersey Central Power and Light Company in South Amboy, New Jersey, through a joint venture among Consolidation Coal Company, B\&W, Texas Eastern Transmission Corporation, and Jersey Central Power and Light Company.

The overall objective of this multi-organizational effort was to demonstrate transportation and utilization feasibility of a coal-based liquid fuel. The CWF was transported by pipelines and over canal and river in barges to a storage depot in New Jersey, before being transported again by barge to the plant in South Amboy, New Jersey, for combustion.

The coal-fired boiler was a pressure-fired, radiant-type unit with primary and secondary superheaters and a reheater in parallel. The boiler was fired with two 9-ft (2.7 meter) cyclone furnaces using coal as a base fuel and oil as secondary fuel. The unit was designed for a maximum continuous rating of $475,000 \mathrm{lb} / \mathrm{hr}$ 
$(215.4$ tons $/ \mathrm{hr})$ steam at $1780 \mathrm{psi}\left(125.1 \mathrm{~kg} / \mathrm{cm}^{2}\right)$ and $1000^{\circ} \mathrm{F}\left(538^{\circ} \mathrm{C}\right)$, and reheat of $375,000 \mathrm{lb} / \mathrm{hr}(170$ tons $/ \mathrm{hr})$ at $462 \mathrm{psi}$ and $1000^{\circ} \mathrm{F}\left(32.4 \mathrm{~kg} / \mathrm{cm}^{2}, 538^{\circ} \mathrm{C}\right)$.

The combustion demonstration lasted for 443 hours, during which time 2.4 million gallons ( 9 million liters) of CWF was burned, resulting in the combustion of over 16 million pounds $(7,331$ tons) of total coal on a dry basis. The boiler operated at approximately $87 \%$ efficiency, which was somewhat lower than that normally achieved with coal. The turndown ratio of the cyclone furnaces with CWF $^{1}$ firing was also acceptable. The furnaces tapped slag readily at half load $(234,000 \mathrm{lb} / \mathrm{hr}$ or 106.1 tons $/ \mathrm{hr}$ steam). The cyclone-furnace turndown with CWF was comparable to that with dry coal.

Based on the $\mathrm{SO}_{2}$ and $\mathrm{SO}_{3}$ measurements, the $\mathrm{SO}_{3}$ concentration in the flue gas of the CWF combustion was comparable to dry pulverized-coal firing and, for that reason, the low-temperature corrosion from the slurry combustion was not greater than that obtained for dry pulverized coal.

Overall, the performance of the boiler showed that CWF could be fired in a manner similar to oil.

\subsubsection{Combustion Demonstration in the Santa Gilla 35 MWe \#2 Boiler in Italy [22-24]}

The Santa Gilla \#2 boiler, an oil-fired unit in Sardinia, was converted to CWF operation in 1987 with assistance from $A B B / C E$. Modifications to the boiler included installation of new firing corners, $A B B / C E$ burners, and an ash removal system [22]. The boiler generated steam at a rate of $297,000 \mathrm{lb} / \mathrm{hr}, 953^{\circ} \mathrm{F}, 1322$ psi (135 tons $\left./ \mathrm{hr}, 512^{\circ} \mathrm{C}, 93 \mathrm{~kg} / \mathrm{cm}^{2}\right)$. The unit had eight tangential burners on two planes, as discussed in reference 22, and used the same windbox found in original fuel oil burners.

${ }^{1}$ CWF was made from ordinary pipeline slurry that was burned in a cyclone furnace. The CWF was not a stabilized suspension of the type normally fired in demonstration projects that utilize a pulverized coal-fired boiler. 
The experimental programs to investigate the combustion efficiency [23] and fouling deposition propensity [24] were presented at the Fifteenth International Conference on Coal \& Slurry Technologies in 1990.

The CWFs for these programs were supplied by Snamprogetti and used two U.S. coals. The solids content of both CWFs was approximately 67\%. MCCall and MAPCO coal companies supplied the coals for the CWFs that, respectively, had $19.5 \%$ and $21.9 \%$ volatile contents on an as-received basis.

The results of the test runs conducted from November 1988 through May 1989 include observations on the carbon conversion efficiency, composition of the flue gas, characteristics of the fly ash [23], deposit characteristics, and deposition mechanism and rates [24]. This demonstration project is described in more detail as follows:

Combustion Efficiency: The atomization quality, furnace residence time, and excess air level are among important parameters that influence combustion efficiency (achieved up to $97.5 \%$ ). The derating depended on the rank of the coal contained in the CWF. To obtain the maximum combustion efficiency, an excess air level of $35-40 \%$ was required.

Flue Gas Composition: The composition of all major species in the gas was monitored. Increased combustion efficiency resulted in increased $\mathrm{NO}_{\mathrm{x}}$ emissions, a) though in general, the $\mathrm{NO}_{\mathrm{x}}$ concentrations were in the range of those produced by pulverized-coal combustion. The sulfur in the coal was emitted as sulfur dioxide $\left(\mathrm{SO}_{2}\right)$.

Fly Ash Characteristics: As observed in pulverized-coal combustion, the particle size distribution of flyash was nearly bimodal. The mass median diameter of fly ash was between 30 and 100 microns, dependent upon combustion efficiency. The flyash produced during the CWF combustion had lower resistivity than that produced by pulverized-coal combustion.

The deposition rates were low at the gas outlet of the combustion chamber. The deposition rates observed when firing MAPCO coal showed a dependence on the 
boiler load; however, the deposit chemical composition did not change with boiler load.

\subsubsection{Himeji \#1 Boiler of the Kansai Electric Power Co. (33 MWe) [25]}

The unit for this combustion demonstration in Japan was the Himeji \#1 boiler, which was rated 33 MWe. The boiler was designed and built in 1955 by the Ishikawajima-Harima Heavy Industries Co. (IHI) to fire pulverized coal, but was converted to burn oil in 1973.

The boiler, front-firing and balanced-draft, had eight burners (each of about 3.8 tons/hr rating) capable of using CWF or oil and rated to raise the designed output $(330,750 \mathrm{lb} / \mathrm{hr}$ or $150 \mathrm{ton} / \mathrm{hr}$ steam). The burner, developed by IHI, was an internal mixing type atomized by steam. The combustion period was August 1986 to July 1987.

Two coals, one imported by Japan ( $\operatorname{Coal} A)$ and the other local (Coal B), were selected for the CWF production. The imported coal had high ash (17.5\% versus $12.5 \%)$ and the domestic coal had high moisture $(6.4 \%$ versus $1.8 \%)$, on an asreceived basis. The source and origin of coals used to prepare CWF were not mentioned [25].

The CWF made for Coal A (which had a lower volatile matter content than Coal B, Appendix $C$ ) required fine adjustment of burner vanes and maintenance of a high furnace temperature to achieve stable combustion. On the other hand, CWF from coal $B$ burned, with ease and its combustibility was judged to be as good as the combustibility of Coal B alone.

The lower load limit for stable operation with CWF firing was observed when the output was turned down gradually from the rated 33 Mwe. The boiler operation was stable, even on four burners, without support fuel at $30 \%$ load (10 MWe). This is comparable to oil firing and better than minimum load (12 MWe) for pulverized coal. In this manner, burner turndown was approximately $3: 1$ during CWF firing. 
The $\mathrm{NO}_{\mathrm{x}}$ emissions for the combustion of CWF (made from Coal B) were about $200 \mathrm{ppm}$, corrected to $6 \% \mathrm{O}_{2}$. Oxygen and unburned carbon levels in the fly ash were $1 \%$ and $1.5 \%$, respectively. The $\mathrm{NO}_{\mathrm{x}}$ emission was lower than, and the unburned carbon amount was comparable with, that produced by pulverized-coal combustion.

Some wear was observed on the burners after 400 hours of operation. However, it was reported [25] that the protection offered by ceramic sleeves on the wearprone sections should provide a burner life expectancy of 2000 hours.

\subsubsection{Demonstration of Low-Ash CWF Combustion on a 110-Ton/Hr Oil-Fired No. 2 Boiler at Hokkaido Oil Refinery of Idemitsu Kosan $\mathrm{Co} .(30.3 \mathrm{MWe})$ [11]}

The demonstration project was conducted using an industrial boiler, firing heavy oil, located at Idemitsu Kosan Co.'s oil refinery in Tomakomai, Japan. The boiler was a front-fired (by 4 burners), forced-draft Mitsubishi CE single-drum radiation type, which had a maximum steam flow rate of 110 tons/hr $(242,550$ $\mathrm{lb} / \mathrm{hr}$ ) at $130 \mathrm{~kg} / \mathrm{cm}^{2}$ and $540^{\circ} \mathrm{C}\left(1848 \mathrm{psi}\right.$ and $\left.1004^{\circ} \mathrm{F}\right)$. The overall objective of this demonstration was to validate that low-ash CWF could be used with minimum modification of the existing unit and to determine the derating required to use CWF.

The boiler modifications included reinforcement of the furnace bottom to handle the added load of ash and protect the water tubes (near the bottom of the boiler) from the ash deposits expected from firing CWF. Six wall deslaggers were also added to remove ash deposits on the front and sides of the furnace walls. Overfire air ports on the side walls were provided for two-stage combustion to control $\mathrm{NO}_{\mathrm{x}}$ emissions. A bag filter was installed to collect flyash.

To control $\mathrm{SO}_{2}$ emission, a low-ash (1.6\% ash, on an as-received basis) Cerrejon coal from Colombia having $0.5 \%$ sulfur (on dry ash-free basis) was used to prepare CWF for this project. The coal had a volatile matter content of 39.3\% (dry). The CWF had a solids loading of approximately 65-66r and a high heating value of $9,300 \mathrm{Btu} / \mathrm{lb}(21.63 \mathrm{MJ} / \mathrm{kg})$. 
The performance of the boiler was examined under two boiler loads of 80 and 70 tons/hr of steam. Satisfactory performance was observed for both loads. The minimum allowable load for control was approximately 35 tons/hr of steam, which was comparable to that for oil firing.

$\mathrm{NO}_{\mathrm{x}}$ emission levels for each of the two boiler loads was less than $350 \mathrm{ppm}$ with an overfire air ratio of $15 \%$. A good carbon burnout was observed.

The burner nozzle was protected from wear with tungsten carbide. The wear, measured $(0.024 \mathrm{~mm}$ or $.0009 \mathrm{inch})$ over 977 hours of operation, showed the burner nozzle to have more than 10,000 hours of life expectancy.

It was determined that the optimum length of continuous combustion was two to three months at the boiler steam output of $70 \mathrm{tons} / \mathrm{hr}(154,350 \mathrm{lb} / \mathrm{hr})$.

\subsubsection{Project at the 22.5-MWe Chatham Station 2 of the New Brunswick Electric Power Commission, Canada $[5,26]$}

This project and the one described in Section 2.3.1 included three basic tasks: (1) construct and operate a continuous CWF preparation plant, (2) transport the CWF product by railroad to the generating station 440 miles ( 708 kilometer) away, and (3) demonstrate CWF combustion in front wall-fired boiler at the 12.5-MWe Chatham Station 1 (Section 2.3.1), and the tangentially fired 22.5-MWe boiler at Chatham Station 2.

The Chatham No. 2 boiler was an ABB/CE tungentially fired, balanced-draft unit producing 22 MWe. It was designed to burn New Brunswick coal but was converted to burn No. 6 oil. The boiler was designed to raise $210,000 \mathrm{lb}$ of steam per hour (95.2 ton/hr).

Prior to firing CWF, a detailed inspection of the unit was performed to identify potential problems and modifications were made. The modifications included cleaning the tubular air heater and installation of spacers in the superheater to return the unit to near-original condition. 
The unit has 4 burners, and each burner is rated at $70 \mathrm{MBtu} / \mathrm{hr}$ ( $7 \mathrm{Mwe}$ ). The burners in Unit 2 had tungsten carbide protection for wear resistance. Air and steam were used as the atomizing media. This boiler, fitted with an $A B B / C E$ developmental CWF burner, produced a boiler efficiency of $85 \%$ when firing $0 i 1$ and between 68 and $72 \%$ when firing CWF.

Approximately 2000 tons (4410 lb) of CWF was burned [5] during combustion on Unit 2. The fuel was supplied by the Cape Breton Coal Development Co. (CBDC) for all of the Canadian CWF demonstration projects discussed in this report.

\subsubsection{Maritime Electric Co.'s 20-MWe unit at Charlottetown, Prince Edward}

The boiler utilized in this project was a two-drum, forced-draft, pressurized, sterling design built by B\&W. It had ar integral furnace with an exit screen, followed by primary and secondary superheaters. The boiler produced 200,000 $1 \mathrm{~b} / \mathrm{hr}$ of steam at $850 \mathrm{psig}$ and $900^{\circ} \mathrm{F}\left(90.7\right.$ tons $\left./ \mathrm{hr}, 59.75 \mathrm{~kg} / \mathrm{cm}^{2}, 448^{\circ} \mathrm{C}\right)$. No major boiler modifications were made for this demonstration except for conversion to balanced draft by the addition of an I.D. fan. This installation/modification was necessary to overcome the pressure loss across a fabric filter installed for particulate control.

The CWF was supplied by the CBDC CWF preparation plant. The plant used Carbogel technology to manufacture the CWF since CBDC is licensed to manufacture CWF for eastern Canada. The raw coal used for this slurry was a high-volatile bituminous coal received from the Victoria Junction coal wash plant that contained, on an as-received basis, $8.5 \%$ moisture and 5.0\% ash. After processing, the CWF contained $30 \%$ moisture and $1.2 \%$ ash.

The use of five Coen burners continued from September 1986 to July 1987. The Coen burners were rated at $544 \mathrm{MBtu} / \mathrm{hr}(573,920 \mathrm{MJ} / \mathrm{hr})$. Another burner system, developed jointly by CANMET and EMR, was tested for two months (August-September 1987). CWF was burned for approximately 642 hours over the course of the entire project. The maximum output was $19.5 \mathrm{MWe}$, and the boiler efficiency was $83.18 \%$ 
using CWF. This efficiency was comparable with that achieved when firing oil $(85.4 \%)$.

The initial prediction for boiler derating was about 50\%. In fact, the boiler obtained $90-95 \%$ of the full load capacity of 20 MWe. The only limitation on the capacity was the flue gas filter and the ash removal system.

During the 642 hours of CWF operation, no significant deposition problem was observed. There was no need for cleaning and no significant tube erosion was observed.

\subsubsection{CWF Combustion in Korea's Yukong Ltd. (18.7 MWe) Modified Boiler [28]}

Yukong Ltd., assisted by U.S. companies, set up a $660 \mathrm{bbl} /$ day $(104,920 \mathrm{liter} /$ day $)$ CWF preparation plant, completed the modification of a $68 \mathrm{ton} / \mathrm{hr}$ of steam, 0ilfired boiler located at a refinery site near the Ulsan area, and conducted unsupported firing of the CWF. The retrofitted boiler was a $150,000 \mathrm{lb} / \mathrm{hr}(68$ ton/hr) steam unit built by Mitsubishi in 1967. The original boiler was fired by \#6 oil and operated at 615 psi $\left(43.23 \mathrm{~kg} / \mathrm{cm}^{2}\right)$ superheated steam. Four burners were located in the front wall. As part of the retrofit, three access ports were installed on one wall and a new sootblower was installed near the superheater section. The furnace did not have a furnace hopper. Four B\&W burners on the front wall were used to fire CWF. The atomizer, using steam as the atomization fluid, was a modified T-jet B\&W type with tungsten carbide inserts.

The liquid slurry fuels were made from two coals: an Australian coal with 6.7\% ash and $37.4 \%$ volatile matter content, and a Chinese coal with higher ash content (13\%) and lower volatile matter content (32\%), both analyzed on an as-received basis. The slurries had $67 \%$ solids loading with a total heat value of 9,346 Btu/1b $(21.73 \mathrm{MJ} / \mathrm{kg})$.

The furnace was started with natural gas support until stean flow was established. However, once the CWF flame was stable, the support fuel was no longer required. Preheating the CWF improved flame stability. Tungsten carbide inserts protected the burner tips, but no related details were provided. The $\mathrm{NO}_{x}$ 
emission level was within the acceptable standard. The emission level of $\mathrm{SO}_{\mathrm{x}}$ was probably not a factor because of the low sulfur content of the coals $(0.5-1.0 \%)$.

\subsubsection{Coal-Fired 60-ton/hr Steam Boiler (15 MWe) of the Beijing First Paper Mill [29]}

Two projects were conducted in China. The first CWF combustion trial in China, discussed in Section 2.3.6, utilized a 20-ton/hr oil-fired unit (5.5 MWe) in 1984-85. Following a successful demonstration $[30,31]$ on this unit, a roject on a 60-ton/hr unit (15 MWe), also oil-fired, was conducted during 1985-87. Both projects used slurry fuels made from coals mined in China.

The boiler for the 60 -ton/hr $(132,300 \mathrm{lb} / \mathrm{hr})$ demonstration project was a doubledrum, water-tube unit with a convection superheater, an economizer, and an air preheater. The unit had six wall burners to fire CWF. The atomizers were the internal mixing type, which used the superheated steam as the atomizing medium.

The CWFs (with solids content of $66.6-68.0 \%$ ) were preheated to about $80^{\circ} \mathrm{C}$ $\left(175^{\circ} \mathrm{F}\right)$ to reduce viscosity and improve atomizing quality.

It was shown that CWF can be burned in a unit designed to fire coal with slight boiler modification. The burners axial swirling registers assisted in CWF ignition and combustion, thereby promoting carbon conversion efficiency that ranged from 95-98\%.

The emission levels of $\mathrm{SO}_{2}$ and $\mathrm{NO}_{x}$ were lower than the acceptable government specifications. Since no dust collector was used, the fly ash escaped with the exhaust gas.

The nozzles used in this combustion project were protected by tungsten carbide or an alloy of tungsten, nickel, and cobalt and showed good abrasion resistance. 
2.3 COMBUSTION DEMONSTRATION ON UNITS RATED IN THE 1-15 MWE RANGE

Ten projects were conducted on units rated in the 1-15 MWe range. The units supplied steam for heating purposes. Details on each of the projects in this size range follow.

\subsubsection{Project at 12.5-MWe Chatham Station 1 of the New Brunswick Electric Power Commission, Canada $[5,26]$ (Refer to Section 2.2.7 for Station 2 Project)}

The Chatham Station 1 boiler was a Foster Wheeler (FW) balanced draft unit designed to produce 12.5 MWe and burn New Brunswick coal. It was converted to No. 6 oil in the early 1960s and used previously for evaluation of coal-oil mixtures. This boiler was refitted with FW/Forney CWF burners for this demonstration. The boiler performed at an average efficiency of $84 \%$ when firing No. 6 oil and 78\% when firing CWF. The operation of the boiler during CWF combustion was fairly routine and switching from oil to CWF and back under load could be done routinely.

Prior to using CWF on the unit, the detailed inspection of the boiler at Station 1 was carried out, but no attempt was made to bring the unit to the original new condition. However, the emphasis was placed on being able to obtain reproducible results during testing with oil and CWF [26]. Air infiltration through the boiler casing was reduced, and insulation and refractory were replaced, as necessary. The boiler and air preheater gas passes were cleaned and the sootblowers were examined. They were found to be not operational, but no effort was made to repair them due to the problems of obtaining spare parts [26].

The FW/Forney burners produced a higher boiler efficiency but turndown ratio and atomization experience n.ere not discussed. The ABB/CE burner system has achieved a 2:1 turndown ratio with carbon conversion efficiency in the 87-91\% range at the Chatham Station 2 (22.5 MWe). The boiler efficiency was about 74-77\% when firing CWF. 
Approximately 1000 tons of CWF was burned [5] during combustion in the unit at Station 1. The fuel was supplied by CBDC for all of the Canadian CWF demonstration projects discussed in this report.

The demonstration projects on Stations 1 and 2 at Chatham justified further CWF use on a small, compact oil-designed utility boiler in Charlottetown, Prince Edward Island.

\subsubsection{Demonstration at the B\&W Nuclear Equipment Division in Barberton, 0hio (8.1 MWe) [32]}

The South Point Partnership, a joint venture of B\&W and Ashland 0il Company, contracted with B\&W's Nuclear Equipment Division (NED) to convert an existing coal-fired unit (8.1 MWe) to a CWF-fired unit that could supply 65,000 ib (29.47 tons) of saturated steam per hour at $125 \mathrm{psi}\left(8.79 \mathrm{~kg} / \mathrm{cm}^{2}\right)$.

This B\&W boiler was built in 1948 to burn pulverized coal. In the early 1970s the unit was converted to fire natural gas; therefore, all of the equipment needed for coal firing was removed. The unit was modified and CWF was burned for two heating seasons in 1984-1986.

The CWF supplied by the South Point Joint Partnership had a solids content of $71.8 \%$ and a heating value of $10,208 \mathrm{Btu} / \mathrm{lb}(23.743 \mathrm{MJ} / \mathrm{kg})$. The slurry fuel was prepared from a 2:1 blend of Pond Creek Seam coal and Pocohontas Seam coal, and preheated in a shell-and-tube heat exchanger to $150-220^{\circ} \mathrm{F}\left(65-104^{\circ} \mathrm{C}\right)$ prior to combustion. A total of 810,000 gallons ( 3 million liters) of CWF was delivered to the site by rail tanker.

A modified B\&W T-Jet atomizer protected by tungsten carbide was used for the CWF demonstration. Combustion was initiated with gas and, once the steam flow was established, the fuel was switched to CWF. The burner turndown rate was $3: 1$ with steam atomization and 4:1 with air atomization.

Because the boiler was fired with gas prior to this CWF demonstration, a mechanical dust collector was installed. The dust collector operated 
satisfactorily but the hopper had to be struck occasionally to dislodge ash deposits.

The boiler was operated continuously, seven days per week at loads of 50,000 $1 \mathrm{~b} / \mathrm{hr}$ (22.67 tons/hr) of steam with natural gas firing. Higher loads were not possible due to the I.D. fan capacity limitation. The carbon conversion for this CWF combustion demonstration was equivalent to that for the pulverized-coal combustion. The boiler availability was about $96 \%$ and reliability was about $87.5 \%$ for the overall system. The level of emissions, the carbon conversion efficiency, and all other performance characteristics were equal to or better than had been expected.

It was concluded that CWF firing does not degrade boiler reliability with the proper selection of parent coals to avoid any ash deposition problems and that the technology exists to permit routine commercial operation of a boiler with unsupported CWF firing.

\subsubsection{EPRI/DuPont Industrial Boiler Demonstration (7.5 MWe) [33]}

A 30-day, full-scale CWF combustion test was conducted on a $60,000-1 \mathrm{~b} \mathrm{steam} / \mathrm{hr}$ (27.20 tons/hr) industrial steam boiler $(7.5 \mathrm{MWe})$ at $175 \mathrm{psig}$ or $12.3 \mathrm{~kg} / \mathrm{cm}^{2}$ (August 13-September 17, 1983). The boiler was a standard design built in 1951 by B\&W and intended for coal-firing by spreader-stoker, but retrofitted with oil burners.

During this test period, two manufacturers provided 2400 tons of slurry with solids content of 70-74\%. The combustion air was preheated and CWF was fired in the oil burners through a B\&W T-jet atomizer with compressed air for the atomizing fluid.

Ash deposits and buildup were observed but could be removed easily by sootblowers. The efficiency of the unit was comparable to that achieved with natural gas and the emissions were similar to those observed with pulverizedcoal firing. 
In summary, the project showed that CWF combustion was feasible and did not negatively impact the furnace performance and emissions.

\subsubsection{Combustion of CWF at Valleydale Packers (7.5 MWe) [34]}

A coal-water fuel combustion demonstration project at Valleydale Packers, Inc. (Bristol, VA) showed that CWF produced by United Coal Company could be fired successfully in a package boiler designed for natural gas and oil firing. Test data was collected over a ten-day period in November 1984 . The fuel contained 61-64\% Virginia high-volatile bituminous coal (55.36\% carbon, 30.21\% volatile, $5.89 \%$ ash, and $7.40 \%$ moisture) with an average fuel heat value of $8,500 \mathrm{Btu} / 1 \mathrm{~b}$ $(19.77 \mathrm{MJ} / \mathrm{kg})$.

The package boiler was designed by Union Boiler Co. and rated at 60,000 Ib (27.2 tons) saturated steam (150 psig, $10.5 \mathrm{~kg} / \mathrm{cm}^{2}$ ) per hour. For CWF firing, the boiler was operated at $45,000 \mathrm{lb} / \mathrm{hr}$. Examination of potential derating factors had indicated the possible corrosion of the first tube bank by the highvelocity combustion flue gases at higher loads. Prior to the demonstration project, a number of instruments, such as flow meters and thermocouples, were added to the boiler.

A Peabody PK-54 burner was used to fire the CWF. The ignitor performance was poor at high swirl rates. The modified Peabody dual fluid atomizer performed well at low CWF input rates. Compressed air was used as the atomizing fluid.

The CWF was introduced after a stable flame was obtained with natural gas. The natural gas supply was decreased as the CWF flow was increased. However, natural gas was required to maintain a stable flame with CWF firing. The preheated CWF did not atomize well.

It was observed that the furnace exit gas temperature did not change significantly from that experienced with oil firing. The furnace exit gas temperature was slightly higher when firing natural gas, probably due to lower furnace heat absorption from the less radiant gas flame. The boiler efficiency 
when firing CWF dropped approximately 8 percent compared to $0 i 1$ and 4 percent compared to natural gas firing.

As expected, the emission of nitrogen and sulfur oxides increased as the steam flow was increased. The sulfur content of the parent coal in the CWF fired was $1.1 \%$ compared with $2.0 \%$ for the 011 . However, it was concluded that the absolute emission of $\mathrm{SO}_{2}$ was about the same since both fuels contained about 1 ib sulfur/MBtu. The amount of particulate matter emitted was proportional to the amount of CWF fired and, as expected, the emissions were dependent on the percent of the boiler heat input supplied by CWF.

No material erosion on internal parts was observed during the ten-day CWF combustion period. All nozzle pieces were constructed of hardened steel with no additional erosion protection.

It was concluded that the CWF can be burned adequately in a package boiler designed to burn natural gas and/or oil at loads of $10-50 \%$ of rated capacity. It was found that the atomizer capacity was too small to handle full load. Use of a large-capacity atomizer would allow loads to be increased. With a larger atomizer, it was projected that the unit could have achieved up to $75 \%$ 10ad without any impact on combustion performance, tube material erosion, or burnout efficiency.

\subsubsection{Combustion Demonstration of CWF in an 0il-Fired Boiler in Sundbyberq. Sweden $(6.87$ MWe) $[35,36]$}

This demonstration project, a joint effort between industry and Sweden's Thermal Engineering Research Institute (and its members), was conducted with financial support from Sweden's National Energy Administration (50\%) at the Sundbyberg District Heating Plant's boiler located near Stockholm.

The boiler (6.87 MWe), manufactured by Svenska Maskinverken, was constructed in 1973, and supplied 55,000 lb (25 tons) of steam per hour at $797 \mathrm{psi}\left(56 \mathrm{~kg} / \mathrm{cm}^{2}\right)$ and $900^{\circ} \mathrm{F}\left(482^{\circ} \mathrm{C}\right)$. The boiler was equipped with two $\mathrm{ABB} / \mathrm{CE}$ burners. The CWF prepared and supplied by Nycol $A B$ had a solids content of $70 \%$. The coal for the 
fuel supply was a high-volatile, low ash (2-3\%) and sulfur $(0.5 \%)$ bituminous coal from the eastern United States.

The combustion demonstration was initiated in February 1983. However, the burners did not perform satisfactorily and were sent back to $A B B / C E$ for modification and testing. After reinstallation, successful operation was established at the heating plant; the demonstration resumed in February 1984 and continued for over 1400 hours. However, satisfactory CWF combustion required use of fine coal. The burner turndown ratio was $3: 1$ at full load with an air/fuel ratio of 0.16 . The superheater was free from any deposits despite the narrow passages provided in the boiler design.

The variation in slurry quality caused some nozzle wear with a maximum wear of about $0.2 \mathrm{~mm}(.007 \mathrm{inch})$. However, this wear did not cause any combustion problems, and the nozzle life expectancy was still estimated to be greater than 2000 hours.

Because of low ash and sulfur content, no problems with emission of sulfur oxides were reported. Volumetric sulfur emissions were reported in the 400-500 ppm range. $\mathrm{NO}_{x}$ emissions were in the 200-300 ppm range. Additional data on the emission of trace metals (lead, nickel, and mercury, for example) were also reported [36]. Heavy metals such as mercury were captured in the fly ash and removed from the flue gas by the baghouse.

\subsubsection{Combustion Experiments on 0il-Fired 20-ton/hr Steam Unit, China (5.5 MWe) $[30,31]$}

The first successful experiment was performed in August 1984. The total combustion time was about 26 hours during which approximately 100 tons of CWF made from Bayi and Fushun coals was combusted.

A low-pressure swirl atomizer developed by Zheijiang University was used. It consisted of a screw body, a swirl cavity, and an atomizer. The atomization medium was steam. 
Boiler and combustion efficiency data were collected, and the effects of tertiary air and special jets (at the furnace bottom to raise furnace efficiency) were also monitored. However, the tests were not performed under optimum conditions since the fan capacity was not sufficient. This resulted in low oxygen content in the combustion gas at the furnace exit.

The combustion efficiencies were 93-95\% for CWF from Bayi coal and 95-96\% for CWF from Fushun coal. The lower combustion efficiency for the Bayi CWF was probably due to lower volatile matter content and insufficient oxygen.

\subsubsection{Three Commercial Projects of Svenska Fluidcarbon Technology [37]}

The status, including the start-up and preliminary operating experience, of three commercial tests of CWis produced by Swenska Fluidcarbon of Sweden were discussed by Linder and Rorgren [37]. Little information about the fuel composition and properties are available, but a Polish coal was likely used to prepare CWFs for all of the three contracts. Raw coal data for the Polish coal are discussed by Stigsson [38].

Energy Utility of Lund (10 MWe) [37]

After successfully completing a long-term demonstration on the utility's boiler during 1983-85, which included almost 11,000 hours of operation and the firing of over 8,000 tons $(17,640,000 \mathrm{lb})$ of CWF, the Energy Utility of Lund in Sweden contracted with Fluidcarbon for the boiler's conversion to CWF and operation for seven years, beginning in December 1984 .

This medium-sized oil-fired utility boiler (10 MWe) was designed in Germany and manufactured by Generator Industri AB. It was one of the heating-system units that supplied steam and hot water to the University Hospital and the district heating system.

The boiler rating for 011 was 29 MW thermal (10 MWe) and the maximum continuous rating for CWF use is $21 \mathrm{MW}$ thermal (7.2 MWe). Modifications to the boiler provided for ash handling. The boiler was then fired in January 1986 using oil 
and then CWF. The unit began operating in April 1986 and achieved a 3:1 turndown ratio with a redesigned rotary cup burner. At the time the report was provided in 1986, the burner system was providing the same load capacity as the former heavy fuel oil burner.

KF/Foodia $A B(3.0$ MWe) $[37]$

This is a unit of a food processing organization in Steffanstorp, outside of Malmo, Sweden. The plant comprises two units: a larger boiler produced 12.5 ton $/ \mathrm{hr}(27,562 \mathrm{lb} / \mathrm{hr})$ of saturated steam at $21 \mathrm{bar}\left(304 \mathrm{psi}\right.$ or $\left.21.4 \mathrm{~kg} / \mathrm{cm}^{2}\right)$ and the smaller boiler provided 6 tons $/ \mathrm{hr}(13,230 \mathrm{lb} / \mathrm{hr})$. The objective of the commercial contract was to provide the total fuel requirement of the larger unit with CWF (75\% of total fuel requirements). Minor unit modifications were made, primarily to handle the solid inorganic matter in the coal, such as a furnace bottom and a baghouse to collect particles from flue gas, and installation of sootblowers. A major modification involved increasing the evaporator tube spacing to prevent blockage by ash deposits during CWF combustion. During CWF firing, the unit was derated approximately $30 \%$ to 9 tons $/ \mathrm{hr}(19,840 \mathrm{lb} / \mathrm{hr})$.

\section{SAB NIFE Factory (2.87 MWe) [37]}

One of the two fire-tube boilers of an organization manufacturing iron-nickel batteries in 0skarshamn, Sweden, was to be converted to use CWF. The boiler supplied 10 tons $/ \mathrm{hr}(22,050 \mathrm{lb} / \mathrm{hr}$ ) of saturated steam at 12 bar (174 psi or 12.25 $\left.\mathrm{kg} / \mathrm{cm}^{2}\right)$. Since the fire-tube boilers are compact, the use of CWF presented the possibility of an ash deposition problem. The unit was derated and operated with a load of 4 tons $/ \mathrm{hr}(8,820 \mathrm{lb} / \mathrm{hr})$ without any problems. Again, minor modifications to the unit configuration, such as the installation of a baghouse filter and fin-tube economizer, were required.

\subsubsection{Superclean Coal-Water Slurry Demonstration at Pennsylvania State University $(1.8$ MWe) $[8,39,40]$}

With funding provided by the U.S. DOE and the Commonwealth of Pennsylvania, the Pennsylvania State University is conducting a program to determine if a CWF 
containing coal with less than 3.0 wt\% ash and 0.9 wtr sulfur, on a dry basis, can be effectively burned in an oil-fired industrial boiler without adverse impact on boiler rating, maintainability, reliability, and availability.

The demonstration boiler is located at the university's East Campus steam plant in University Park, Pennsylvania. The Tampella Power Corporation (formerly Tampella Keeler) DS-15 package watertube oil-fired (and gas-fired) boiler, nominally rated at $15,000 \mathrm{lb} / \mathrm{hr}(6.8 \mathrm{tons} / \mathrm{hr})$ of $300 \mathrm{psig}\left(22 \mathrm{~kg} / \mathrm{cm}^{2}\right)$ saturated steam, will be used for the demonstration. The details of the auxiliary equipment included in the steam plant are provided in reference 39.

Details of the preliminary testing, which consisted of generating data by firing natural gas and cofiring natural gas with CWF, are discussed in reference 39. Two 500-1000 hour demonstrations are planned. The first demonstration, which began in March 1992, is to evaluate the deposition, corrosion, and erosion characteristics of the CWF. A paper presented in the Seventeenth International Conference on Coal Utilization \& Slurry Technologies discusses preliminary results from the erosion testing [40].

After the first demonstration, the plans are to continue the project to further investigate system performance during a second demonstration. In addition, during this second demonstration a high efficiency, low NO burner will be installed, an emission control system will be added to investigate $\mathrm{SO}_{2}$ and $\mathrm{NO}_{x}$ removal and a superheater module will be incorporated to stimulate larger boilers. The work on this project is continuing.

\subsubsection{B\&W and ABB/CE 100-million Btu/hr (10 MWe) CWF Burner Demonstration' $[5,41,42]$}

By 1984, U.S boiler companies had designed large CWF burners that performed as efficiently as burners firing pulverizud coal. In 1985, EPRI sponsored a program to demonstrate state-of-the-art 100-MBtu/hr burner systems involving three major

'These burner demonstration projects were not conducted on boilers built to raise steam. However, they are included here due to their large sizes (10 MWe). 
boiler companies: $B \& W, A B B / C E$, and Foster wheeler. ${ }^{2}$ A set of ten performance criteria was established by EPRI as targets for the burner systems to meet.

EPRI (USA) PERFORMANCE TARGETS FOR CWF BURNERS $[41,42]$

\begin{tabular}{||l|l||}
\hline \multicolumn{1}{|c|}{ ITEM } & \multicolumn{1}{|c|}{ TARGEI } \\
\hline Burner Turndown & $3: 1$ \\
\hline Atomizing Medium & Air or Steam \\
\hline Atomizing Air Fuel Ratio & 0.15 \\
\hline Atomizer Tip Life & $2,000 \mathrm{hr}$ \\
\hline Dual Fuel Capability & CWF or $0 i 1$ \\
\hline Carbon Conversion Efficiency & $>99 \%$ \\
\hline Air Preheat Temperature & $<300^{\circ} \mathrm{F}\left(<149^{\circ} \mathrm{C}\right)$ \\
\hline Maximum Droplet Diameter & $100 \%--<300 \mathrm{micron}$ \\
\hline Excess Air Level & $<20 \%$ \\
\hline Combustion Air Pressure & $<6$ inch $(153 \mathrm{~mm})$ water column \\
\hline
\end{tabular}

Under this program, EPRI allowed the participants to burn a CWF of their choice and a baseline CWF common to participating organizations. The baseline fuel was produced by Atlantic Research Corporation from a high-volatile bituminous coal. The baseline CWF contained approximately 21-23\% volatile matter with total solids loading of about 70 wtr. Prior to the CWF testing, a baseline test was conducted firing No. 6 oil. A detailed analysis of the baseline fuel is presented in Appendix $C$ and also discussed by B\&W [41], ABB/CE [42], and Faulkner [5].

B\&W used a large test facility owned and operated by Riley Research of Worcester, Massachusetts, whereas ABB/CE conducted combustion tests at its Kreisinger Development Laboratory test facility in Windsor, Connecticut.

Both B\&W and ABB/CE met or exceeded most of the EPRI-established performance targets. However, the maximum droplet size of 300 microns was not achieved,

${ }^{2}$ Foster wheeler, however, did not conduct the demonstration project. 
probably due to the predominance of larger coal particles in the CWF or poor atomization quality. The combustion test length was too short (less than 150 hours) to demonstrate atomizer tip life. However, the $A B B / C E$ burner unit was later used successfully in the Sundbyberg demonstration in Sweden for over 2,000 hours, and the B\&W burner system was used for projects in Memphis, Tennessee, and Barberton, Ohio. It was concluded that these units could achieve the burner performance targets established by EPRI. The test results on the Nakoso \#4 (75 MWe) unit discussed in Section 2.2.2 al so showed that project could achieve these EPRI targets.

The major observations from the burner demonstration projects at $B \& W$ [41] and $A B B / C E[42]$ are as follows:

- Steam atomization achieved higher carbon conversion and lower emissions than air atomization at B\&W.

- Carbon conversion was about $99 \%$.

- Burner turndown ratios of at least 3:1 or better were achievable with CWF use and system performance was satisfactory after switching from oil to CWF.

Both B\&W and $A B B / C E$ demonstrated that their burner systems are ready for commercial application.

\subsection{RESULTS FROM THE DEMONSTRATION PROJECTS}

The design, construction, and operation of a utility boiler is usually based on many factors, including fuel type, source, fuel characteristics and composition, boiler design, load, and operating conditions. In general, the CWF projects discussed in this report demonstrated the feasibility of burning CWF in boilers designed for firing coal or oil. The factors discussed below address the economic and technical aspects of converting boiler systems to CWF firing. 
Analyses of the CWFs used in the major projects are listed in Appendix C. In this table, the analyses are presented on an as-received basis unless the source listed the composition only on a dry basis. Wherever possible, analyses of the parent coal and the CWF prepared from the parent coal are listed under the heading "Fuel Form" in Appendix C. The majority of projects used CWF containing about 70 wt $\%$ solids; however, some projects used CWF containing as high as $74 \%$ and as low as 60-64\% solids. It is believed that approximately 1 wt $\%$ additive was used in the fuel formulation to improve stability and flow properties, but the additive content was rarely identified or its composition included in the fuel analysis for the project.

Most countries used domestic coals to manufacture CWF. Canada, China, Japan, and the U.S. are mentioned here as examples of such countries. The Canadian projects used coals from the U.S. as well as the domestic coal from Nova Scotia. Japan has used at least one U.S. coal [10], but none of the other coals are clearly identified. Sweden used a U.S. coal for the Sundbyberg project and a Polish coal for its commercial contracts. Appendix $C$ lists the typical composition of a coal from poland, since the analyses of fuels for commercial contracts were not provided.

All countries used coals that contained high levels of volatile matter. An exploratory project conducted in the period 1982-83 at the Santa Barbara Unit in Italy [17] included a coal that contained only 178 volatile matter. However, since the CWF was co-fired with another fuel, it is not possible to state whether this fuel could have been successfully fired alone. In CWF preparation, the use of coal with the highest possible volatile matter content is advantageous because it provides ease of ignition and a stable flame in the presence of water vapor. For this reason, the CWFs were produced from coals which contained at least 258 volatile matter on a dry basis. Metallurgical coals that contain volatile matter in this range have also been used to formulate CWF and have been successfully burned in the demonstration projects of Canada (Chatham Stations) and Sweden (commercial contracts). 
As in the use of any fuel, the amount of noncombustible materials (i.e., ash) should be minimized. This was particularly important for those projects that demonstrated CWF combustion on units designed to burn oil. It was necessary to modify these boilers, particularly if they were as small and compact as the units used in the Swedish commercial projects, in order to accommodate and handle noncombustibles generated during CWF combustion. Even when low-ash (less than $4 \%$ ash in the (WF) fuel was used for the commercial projects in Sweden, the boilers had to be modified considerably to fire CWF, including installation of a sootblower and particulate removal equipment to clean combustion flue gases. The ash content of CWFs used in other projects varied; the CWF from a coal containing as high as 25 wt\% ash was used in a Japanese project (600 MWe Nakoso \#8).

\section{Boilers for CWF Combustion Demonstration}

The majority of demonstration projects utilized boilers designed to fire oil or natural gas (Appendix B). The units larger than 100 MWe were designed either for mixed-fuel firing (Japan Nakoso \#8), or oil firing (Boston Edison). On these larger units, the CWF combustion provided only part of the heat to raise the load. Most of the units rated in the 1-100 MWe range were designed to use oil as fuel. Demonstration projects in Canada (Charlottetown), Italy (Santa Gilla), Korea, China (60 ton/hr or 132,300 lb/hr unit), Sweden (Sundbyberg and Commercial Projects of Swenska Fluidcarbon), and the U.S. (Boston Edison, Valleydale Packers and Pennsylvania State University) were all designed originally to fire oil. The DuPont Co., like projects in other countries, used CWF in its Memphis, Tennessee unit, which was built to use coal but converted to use other fuels. The economics of conversion to CWF should be more favorable in such cases.

\section{Modification of the Boiler for CWF Use}

When demonstration projects were conducted using units designed for coal or units currently burning mixed fuels that include coal (such as the projects at South Amboy, New Jersey, South Carolina Electric \& Gas, and the Nakoso \#4 and \#8 units in Japan), the presence of ash in CWF did not significantly impact unit performance. These units could readily use CWF with minor modifications to the burner and atomizer systems. However, when the combustion demonstration was 
conducted on units designed to burn other liquid or gaseous fuels that do not contain significant amounts of ash, the units required major modifications to handle the larger quantities of ash resulting from the combustion of this coalbased fuel. Such modifications included the addition of an ash hopper to handle residual ash, installation of sootblowers to clean boiler surfaces, and removal of particulate matter from the flue gas by incorporating a fabric filter.

Units designed to fire oil or gas should be examined carefully prior to CWF use, as was done in the demonstration project on the Valleydale Packers unit in Bristol, Virginia. In a majority of units used for the demonstrations, it was necessary to remove ash from the unit or from the combustion flue gas. If the unit used in the demonstration project is compact and small, as in the commercial projects of Svenska Fluidcarbon, the heat exchanger tube spacing would have to be modified to prevent ash deposition and plugging. In other words, case-by-case evaluation is the preferred approach based on the boiler design, current fuel use, and the type of CWF and its parent coal composition.

\section{Burner/Atomizer System}

Since CWF is a particle-laden liquid fuel, early CWF projects used a burner/atomizer system that was originally designed to burn oil. However, the erosion of burner and atomizer parts by this solid-laden fuel presented problems. The burner/atomizer area, which is exposed to high-velocity CWF flow, showed wear, which prevented fine atomization of the fuel. For this reason, most projects used protection (ceramic or other hard material such as silicon carbide and tungsten carbide) on wear-prone areas of the burner, such as tips and nozzles. Both Japan (Nakoso units $\# 4$ and $\# 8$ ) and the U.S. (projects by EPRI at $B \& W$ and $A B B / C E$ ) have tested high-capacity (up to 100-200 MBtu/hr) burners developed for firing CWF. The Mitsubishi-developed MARC II burner system (200 $\mathrm{MBtu} / \mathrm{hr}$ ), B\&W developed ( $T$-Jet atomizer), and ABB/CE-developed (Y-Jet atomizer) burner systems have been used in major long-term demonstration projects. The Mitsubishi MARC burner system and its modification were used in the project on the Nakoso \#4 and \#8 units. The burner system designed by ABB/CE performed for over 1500 hours in the Sundbyberg demonstration project and probably could have met the 2000-hour life requirement set by EPRI performance criteria. 
A majority of the demonstration projects showed burner turndown ratio potentials between $3: 1$ and $4: 1$ using steam or air. In the B\&W 100-MBtu/hr (10 MWe) burner demonstration project for EPRI, steam atomization achieved higher fuel burnout and finer fly ash. However, the flame stability was better using air as the atomizing medium. As stated before and shown in all successful long-term (longer than 1000 hrs of CWF combustion) projects, some form of protection is required to extend burner tip life expectancy to 2000 hours. Silicon carbide, tungsten carbide, and other ceramic protection provided this long life.

Other countries, such as China and Sweden, have also included separate burner and atomizer development efforts in their programs to suit the coal and/or slurry properties. The rotary cup atomizer developed in Sweden and the burner developed by the Zheijiang University in China are among the results of these efforts. Publications originating from the Pennsylvania State University provide details on the burner development activities of the various U.S. manufacturers [43] and of other countriss [44]. Further work on the development of atomizers and fundamental research on the atomization of dense, particle-laden fluids is continuing.

The units designed for pulverized coal required a burner/atomizer that can inject a CWF. Some projects modified the burner systems used for firing heavy fuel oil. The abrasive particle-laden character of the CWF eroded the atomizer nozzle and burner tips. Severe erosion of these components was visible in the demonstration project at Boston Edison.

\section{CWF Combustion}

The combustion mechanisms of CWF have been studied in many fundamental research programs. The presence of water vapor in CWF delays ignition, which is improved by using coals that have high levels of volatile matter. In a research program which included combustion testing on both bench- and commercial-scale test facilities, Kiga et al. [45] indicated that the combustion rate for CWF is also 
accelerated by the hydro-gasification reaction mechanism ${ }^{1}$ and the combustibility of the char from CWF is better than that of the char from pulverized coal combustion. They also demonstrated that the burner/atomizer system used for their commercial tests achieved stable combustion. Flame stability and burner turndown, which were major concerns in CWF combustion, have been improved with the introduction of new burner and atomizer systems.

A fundamental study [46] exploring the effects of coal fineness and volatile and mineral matter content on the carbon burnout and flyash levels in coal flames shows that early generation of volatile matter in the high-volatile-content coal is instrumental to better flame stabilization close to the nozzle, and both the carbon burnout and fly-ash size distribution are influenced favorably by coal particle size reduction when the atomization quality of the CWF is high.

The combustion mechanism for CWF is similar to that of pulverized coal [7] with an additional stage of water evaporation. The water evaporation after fuel injection delays ignition of the fuel for a few milliseconds. The evaporated volatile matter from the coal is diluted by presence of the water vapor and, in turn, reduces its flammability. This dilution can be counteracted through the use of coals with high volatile matter content and high heating value. Because of the heat absorption by water evaporation in the initial period of CWF combustion, the flame temperature is lower than that for the pulverized coal.

Also, since the coal particle is "enclosed" in the water bubble, the CWF injection includes larger droplets, which requires longer combustion time for each droplet to burn. A reduction in the size of the CWF droplet will result in a decrease in the combustion time, and research is continuing directed toward the development of atomizers that can achieve finer droplets.

${ }^{1}$ Through basic combustion tests, Kiga et al. [45] confirmed that CWF char had a higher reaction rate than char from pulverized coal because char combustion during CWF firing is promoted by the coexistence of water vapor at temperatures higher than $1000^{\circ} \mathrm{C}\left(2032^{\circ} \mathrm{F}\right)$, possibly by reactions

$$
\begin{aligned}
& \mathrm{C}+\mathrm{O}_{2} \rightarrow \mathrm{CO}_{2} \\
& \mathrm{C}+\mathrm{CO}_{2} \rightarrow 2 \mathrm{CO} \\
& \mathrm{C}+\mathrm{H}_{2} \mathrm{O} \neq \mathrm{CO}+\mathrm{H}_{2}
\end{aligned}
$$


The major demonstration projects in Japan (Nakoso \#8 and \#4 units) and the burner demonstration projects funded by EPRI in the U.S. showed carbon burnout levels of better than $99 \%$ for CWF combustion. This resulted from an improvement in the air and fuel recirculation patterns in the new burner/atomizer systems developed and obtained in rapid char burnout. The demonstration project at Santa Barbara, Italy, studied the effects of combustion air preheating and CWF preheating on CWF ignition, flame stability, and overall combustion. Optimization of these parameters created a stable flame, good turndown rate, and high carbon burnout rate. Sometimes, the support of other fuels, such as cofiring with oil or natural gas, was used to achieve flame stability. In all cases, however, CWF modr. from a high-volatile coal can be useful [45]. The selection and utilization of these combustion-supporting techniques is dependent on fuel composition and burner capability. Support fuels may not even be necessary when the CWF provides only part of the heat input to generate the total load.

\section{Ash Behavior and Deposition}

The boilers originally designed to burn oil presented ash deposition problems when CWF was fired and required modifications to accommodate the ash. The extent of the modifications was specific to the boiler design and fuel composition, but most of the units were operated at loads lower than that specified in their design. The units designed to burn coal are likely to present fewer problems when firing CWF than the units not originally designed to burn coal. Generally, it is recommended that oil-fired systems utilize a CWF made from a coal with the lowest practicable ash content in order to minimize problems related to ash.

\section{Emissions}

The $\mathrm{SO}_{\mathrm{x}}$ emission data were reported by the demonstration projects at the Sundbyberg demonstration of Sweden [35] and the Santa Gilla project of Italy [21]. The emission of sulfur oxides was proportional to the amount of fuel fired and, therefore, increases with increased load for these demonstration projects. The approach used to reduce $\mathrm{SO}_{\mathrm{x}}$ emissions resulting from CWF combustion is to use 
a low-sulfur coal to produce the CWF, as was done in the commercial projects in Sweden.

The emission of $\mathrm{NO}_{\mathrm{x}}$ is associated with the nitrogen present in fuel as well as the nitrogen present in the combustion air. High flame temperature increases the formation of $\mathrm{NO}_{\mathrm{x}}$ from the combustion air. The filane temperature is lower with CWF combustion (due to heat lost in evaporation of water in the fuel) than with pulverized-coal combustion. This $\mathrm{NO}_{\mathrm{x}}$-lowering trend when firing CWF was confirmed in several demonstration projects, particularly the Japanese demonstration on the Nakoso \#4 unit [19]. In fact, Shirato et al. [19] 1ist the performance criteria established by the Fuyo Group, which include criteria for $\mathrm{NO}_{\mathrm{x}}$ emission. The following lists the performance targets established by the Fuyo Group for the CWF combustion tests on the Nakoso \#4 (75 MWe) unit.

Targets of Combustion Tests on the Nakoso \#4 (75 MWe) Unit in Japan [19].

\begin{tabular}{|c|c|}
\hline ITEM & TARGET \\
\hline CWF Firing Rate & $100 \%$ \\
\hline Minimum Boiler Load & $<30$ MWe, $40 \%$ full load \\
\hline Load Swing Rate & $3-4 \% / \min$. \\
\hline $\mathrm{NO}_{x}$ at Full Load $\left(\begin{array}{lll}0 & 6 \% & \mathrm{O}_{2}\end{array}\right)$ & $\begin{array}{l}<250 \mathrm{ppm}[\Theta \text { Fuel Ratio }(\mathrm{FR})<1] \text {; } \\
<350 \mathrm{ppm}(\Theta \text { FR }>1.5)\end{array}$ \\
\hline Unburned Carbon in Ash & $\begin{array}{l}<3.0 \%(9 F R<1) \\
<10 \% \quad(9 \text { FR }>1.5) \\
\end{array}$ \\
\hline Burner Tip Life & $>1,000 \mathrm{hrs}$ \\
\hline CWF Pump Life & $>1,500 \mathrm{hrs}$ \\
\hline
\end{tabular}

${ }^{1}$ Fuel Ratio (FR) is defined as the ratio of fixed carbon and volatile matter of the fuel.

From the demonstration project on this 75-MWe unit, the group reported 280-300 ppm $\mathrm{NO}_{\mathrm{x}}$ emissions, which is lower than the established limit (350 ppm at full load). For most CWF demonstration projects, emissions were comparable to, or lower than, that observed for pulverized-coal combustion. 
The emission of particulate matter with the flue gases is a principal factor to be considered in a decision to switch to coal or coal slurry fuel. In several projects, a particulate removal system was installed to remove particles from the combustion flue gas. However, when CWF was fired in the units designed to burn coal, the particulate emission levels were comparable.

\section{Derating}

CWF, unlike other liquid fuels, has considerably higher non-combustible content, (coal inorganic matter and water), and lower per pound heat value than does oil or gas. Thus, when using CWF in systems designed for premium fuel, generally the units must be derated in order to ayoid a serious reduction in combustion efficiency. For smaller, compact units requiring modifications, derating can be significant. Also, the features required in the heat-absorbing surfaces depend on the type of fuel for which the boiler was designed. The CWF demonstration projects operated at various loads, anywhere from $50 \%$ (Swedish commercia) projects) to almost $100 \%$ (no derating, as in the Charlottetown, Canada, and coalfired Japanese Nakoso \#8 units). All aspects related to coal rank, composition, and properties must be evaluated prior to actual implementation of the conversion of the unit to fire CWF, including CWF properties and composition; boiler type, size, and design specifications; and operating conditions.

As indicated, derating may be caused by several factors. Three major factors for derating are the following: (1) the furnace residence time for carbon burnout when using CWF could be too short and therefore require reduced firing capacity; (2) more time may be needed for combustion products (ash particles) to cool prior to entering the boiler convective section, in order to reduce fouling; and (3) at rated capacity using CWF the combustion gas velocity in the convective section may be so high as to cause erosion of or inefficient heat transfer to water tubes and therefore require a lowered firing rate.

\section{Equipment Degradation}

CWF contains solid coal particles which make it more abrasive to pumps, valves, and burner/atomizer systems. This results in material loss due to the erosive 
characteristics of the fluid flowing through the process equipment. Wear of the components was anticipated in most of the projects, particularly those demonstrating CWF use over a long time. Initial observations showed high rates of equipment degradation and wear when no protection was provided. However, a majority of the projects discussed only the life of burner tips and atomizer nozzles. The demonstration project at South Carolina Electric \& Gas showed a high rate of erosion during the initial phase of CWF firing but the erosion rate decreased after this initial phase. Again, the period of CWF use was not long enough in most demonstrations for definitive conclusions of life expectancy, although in most projects wear of the burner tip and atomizer nozzles was monitored and a trend indicating a 2000-hour life was estimated from the wear rate observed. However, no project was abandoned specifically for problems related to wear. This was probably because of the early recognition of the potential for wear and use of preventive measures such as protection of the wearprone components with ceramic or other hard material (e.g., tungsten carbide).

The work of kiga et al. [45] included a comparison of the protection provided by atomizer sleeves made of different ceramic and tungsten carbide materials in long-term combustion testing with CWF. The tests confirmed that the use of ceramic materials as sleeves can increase life of the wear-prone components to more than 2000 hours. Similar trends were observed in the demonstration projects in Japan (Nakoso \#8 and \#4 units) and Sweden (Sundbyberg), where the CWF combustion was of sufficient length to confirm the life of these components.

\subsection{SUMMARY AND CONCLUSIONS}

A number of countries have developed CWF technology and demonstrated that CWF can be fired in existing boilers that currently raise steam. Short descriptions of most of these / rojects were provided.

These demonstration projects were conducted on boilers capable of firing coal, oil, natural gas, and mixed fuels. However, and not surprisingly, the boilers that were originally designed to burn coal were found to be the easiest to convert to CWF firing. These units have built-in provisions for handling the ash 
and deposits associated with the combustion of coal. The conversion to CWF may be even simpler if these units have already been converted to use oil.

A number of factors must be considered to achieve a successful conversion to CWF of systems designed for premium fuel. These factors include the coal type and composition, the need for beneficiation to minimize coal-ash content, and the need for fine-size coal particles combined with efficient atomizers to produce small CWF droplets. The majority of the projects were conducted using small, compact units designed for firing oil. These units required one or more of the following modifications to use CWF:

- replacement of burner/atomizer

- installation of ash removal equipment in the unit

- installation of particulate removal system to clean the flue gases after combustion.

The conversion to CWF will probably force derating of the premium-fuel-fired unit from the existing design specification and the inclusion of emissions controls. The practicality of the conversion, therefore, is also related to load demand, tolerance of the unit to mineral matter, and environmental concerns, all of which are associated with the utilization of coal-based fuels.

The burner/atomizer designs used for CWF can achieve carbon conversion efficiencies of more than $99 \%$ in most instances. The use of fine coals in preparing CWF and further research in atomizer development will improve CWF atomization and consequently the time for complete combustion.

In summary, the required modifications are dependent on the specific boiler and the properties of the fuel and its parent coal. For these reasons, the economics involved in converting a unit to use CWF are related to the cost of the fuel in current use, CWF cost, the extent of modifications required for conversion, and the operating and maintenance expenses associated with CWF firing. 


\section{DISCLAIMER}

Reference herein to any specific commercial product by tradename, trademark, manufacturer, or otherwise does not necessarily constitute or imply its endorsement, recommendation, or favoring by the United States Government or any agency thereof. 


\subsection{REFERENCES}

1. Glenn, R. D., "Coal Slurry Application and Technology," Electric Power Research Institute Final Report, Number GS-7209, August 1991.

2. Thambimuthu, K.V., and Whaley, H., "The Combustion of Coal-Liquid Mixtures," Chapter 4, pp. 337-449 in Principles of Combustion Engineering for Boilers, edited by C.J. Lawn, Academic Press, New York, 1987.

3. Marnell, Paul, "Direct Firing of Coal-Water Suspensions State-of-the-Art Review, "Proceedings of the Third International Coal Utilization Exhibition and Conference, Houston, TX, November 18-20, 1980, p. 486.

4. Bienstock, D., and Foo, O.K., "History and Development of Coal-Liquid Mixtures," Proceedings of the First European Conference on Coal-Liquid Mixtures, Cheltenham, United Kingdom, Institution of Chemical Engineers Symposium Series No. 83, October 5-6, 1983, p. 1.

5. Faulkner, A.R., "CWM Large Burner Development Tests and Demonstrations in the United States and Canada -- 1983-1986," Proceedings of the Eighth International Symposium on Coal Slurry Fuels Preparation and Utilization, Orlando, FL, May 27-30, 1986, p. 717.

6. Makansi, J., "Coal-Water Fuels," Power, Vol. 129, No. 7, July 1985, p. 17.

7. Miller, B.G., "Coal-Water Slurry Fuel Utilization in Utility and Industrial Boilers," Chemical Engineering Progress, Vol. 89, No. 3, March 1989, p. 29.

8. Miller, B.G., and Scaroni, A.W., "The Pennsylvania State University's. Superclean Coal-Water Slurry Demonstration Program," Proceedings of the Fifteenth International Conference on Coal and Slurry Technologies, Clearwater, FL, April 23-26, 1990, p. 223. 
9. Ratafia-Brown, J., "Performance/Cost Criteria for Potential CCTP-2 Technologies," Report prepared for the Pittsburgh Energy Technology Center under DOE Contract DE-AC22-87PC79338, Subtask 9.01, April 1988.

10. Kuroda, H.; Masai, T.; Takahashi, Y.; and Watanabe, S., "Combustion of CoalWater Slurry in a Multiple-Burner Furnace," Proceedings of the Fifth International Symposium on Coal Slurry Combustion and Technology, Orlando, FL, Vol. 1, 1983, p. 502.

11. OKa, N.; Sato, S.; Kondo, T.; and Simoyama, T., "Demonstration Test of Low Ash CWM Combustion in a $110 \mathrm{t} / \mathrm{h}$ 0 11 Designed Boiler," Proceedings of the Sixteenth International Conference on Coal and Slurry Technologies, Clearwater, FL, April 22-25, 1991, p. 575.

12. Anjum, A., and Winnard, S., "Conversion of a 10 MW 0il-Fired Boiler to CWM Firing," Proceedings of the Third European Conference on Coal-Liquid Mixtures, Malmo, Sweden, I. Chem E. Symposium Series No. 107, October 14-15, 1987, p. 259.

13. Ercolani, D.; Minnetti, G.; Belykh, B.N.; Kagan, Y.M.; Kondratier, A.S.; Khodakov, G.S.; Korochkin, G.K.; and Stolyarov, N.A., "The Try-Out of CoalWater Suspension Preparation rransportation, and Combustion Technology on the Belovo to Novosibirsk Coal Pipeline," Proceedings of the Sixteenth International Conference on Coal and Slurry Technologies, Clearwater, FL, April 22-25, 1991, p. 1.

14. Shirato, R.; Sakashita, T.; Yakuki, M.; Sakayori, T.; Hironaka, H.; Nitta, K.; Kaneko, S.; Sakai, M.; and Imamoto, T., "Operation Test Results with 200 MBtu/h CWM Burner at Nakoso $\$ 8$ Unit (600 MW), "Proceedings of the Twelfth International Conference on Slurry Technology, New Orleans, LA, March 31 April 3, 1987, p. 419.

15. Tani, K.; Muto, T.; Kusunoki, K.; Abe, K.; Nitta, K.; Nakayama, T.; Kaneko, S.; and Imamoto, T., "Commercial Operation Results of Partial CWM Introduction at Nakoso "8 Boiler (600 MW)," Proceedings of the Fifteenth 
International Conference on Coal and Slurry Technologies, Clearwater, FL, April 23-26, 1990, p. 1.

16. Faulkner A.R.; Schmid, M.R.; and O'Connor, H.W., "Coal-Water Slurry Barge Delivery to Boston Edison Mystic 4 for a Demonstration Test Burn," Proceedings of the Seventh International Symposium on Coal Slurry Fuels Preparation and Utilization, New Orleans, LA, May 21-24, 1985, p. 1047.

17. DeMichele G.; Graziadio, M.; Ligasachhi, S.; Saccenti, G.; and Salvi, G., "Large Scale CWS Firing Tests at the S. Barbara Power Station," Proceedings of the Fifth International Symposium on Coal slurry Combustion and Technology, Tampa, FL, Vol. 2, April 25-27, 1983, p. 1053.

18. Schaefer, C.F., and Faulkner B.P., "Demonstration of Coal-Water-Mixture Fuel Production and Burning of Utility and Industrial Applications," ASME Paper 85-JPGC-FU-3, presented at the Joint ASME/IEEE Power Generation Conference, Milwaukee, WI, October 20-24, 1985.

19. Shirato, R.; Konishi, H.; Abe, K.; Takahash:, T.; Kaneko, S.; Funatsu, H.; Shoji, K.; Kawano, K.; and Shimpo, I., "Coal Water Mixture Demonstration at Nakoso," Eighth International Symposium on Coal Slurry Fuels Preparation and Utilization, Orlando, FL, May 27-30, 1986, p. 738.

20. Kelcec, G.; Olivadoti, P.P.; and Duzy, A.F., "Coal Slurry Firing at the Werner Station," ASME Paper No. 62-PWR-3, presented at the AIEE-ASME Joint Power Conference, Baltimore, MD, Sept 24-26, 1962.

21. Clancey, J.T., "The Combustion of Coal-Water Slurry Commercial Demonstration at the E.H. Werner Generating Station, "Consolidation Coal Company, Internal Report No. 2, Project 140-F, March 27, 1962.

22. DeMichele, G.; Ligasacchi, S.; and Pasini, S., "CWF Firing on an 0ilDesigned Utility Boiler," Proceedings of the Twelfth International Conference on Slurry Technology, New Orleans, LA, March 31-April 3, 1987, p. 305. 
23. Cioni, M.; Ligasachhi, S.; Ruth, L.; and Hargrove, M., "Combustion of Coal-Water Fuels in an 0il-Designed Boiler: Combustion Efficiency," Proceedings of the Fifteenth International Conference on Coal and Slurry Technologies, Clearwater, FL, April 23-26, 1990, p. 237.

24. Quattroni, G.; Mazzanti, A.F.; Smouse, S.; and Hargrove, M., "Evaluation of Coal-Water Fuel Fouling Propensity in 0il-Designed Boilers, "Proceedings of the Fifteenth International Conference on Coal and Slurry Technologies, Clearwater, FL, April 23-26, 1990, p. 253.

25. Miyamoto, S.; Makino, K.; and Saitoh, H., "Operational Experiences with CWM on 33 MW Himeji \#1 Boiler of the Kansai Electric Power Co., Inc.," Proceedings of the Thirteenth International Conference on Coal and Slurry Technology, Denver, CO, April 12-15, 1988, p. 521.

26. Whaley, H.; Rankin, D.M.; Landry, P.G.; and Covil, I.D., "Utility Boiler Demonstration of Coal-Water Mixture Combustion at Chatham, New Brunswick," Proceedings of the Sixth International Symposium on Coal Slurry Combustion and Technology, Orlando, FL, June 25-27, 1984, p. 519.

27. Executive Summary of "Coal Water Fuel Combustion Demonstration, Charlottetown, Prince Edward Island," a joint project of the Energy Mines and Resources Canada, Maritime Electric Co., Cape Breton Development Corp. and New Brunswick Electric Power Co, March 1988, pp. 29.

28. Kim, T.C., and Kim, S., "Combustion Test Results of Coal-Water-Fuel into Yukong's Modified Boiler on a Commercial Basis Boiler at Yukong," Proceedings of the Thirteenth International Conference on Coal and Slurry Technology, Denver, C0, April 12-15, 1988, p. 507.

29. Zhaoqiang, W.; Xieyue, W.; and Zhixiong, X., "Coal-Water Fuel Combustion on a $60 \mathrm{t} / \mathrm{h}$ 0il-Fired Industrial Boiler." Proceedings of the Thirteenth International Conference on Coal and Slurry Technology, Denver, CO, April 12-15, 1988, p. 533. 
30. Minghu, X.; Deshou, L.; Xinyu, C.; Kefa, C.; Zuna, W.; Fengying C.; Chaoquiang $Y u$; and Chunguang G., "Experimental Study on Coal-Water Slurry Combustion on $20 \mathrm{t} / \mathrm{h}$ 0il-Fired Boiler," Proceedings of the Seventh International Symposium on Coal Slurry Fuels Preparation and Utilization, New Orleans, LA, May 21-24, 1985, p. 761.

31. Kefa, C.; Minghu, X.; Deshou, L.; Xinyu, C.; and Qinghang, J., "Progress in the Combustion of Coal Water Slurry-Laboratory Research and Industrial Scale Experiments," Proceedings of the 1985 International Symposium on Mining Technology and Science, China Coal Industry Publishing House, 1987, p. 1358.

32. Carlson, R.V.; Wilkinson, J.M.; Cartwright, R.A.; and Muckley, J.J., "CWF Firing of an Industrial Boiler on a Commercial Basis," Proceedings of the Eighth International Symposium on Coal Slurry Fuels Preparation and Utilization, Orlando, FL, May 27-30, 1986, p. 910.

33. Perkins, R.P., "Coal-Water-Slurry Test in an Industrial Boiler," Electric Power Research Institute Final Report CS-4268, September 1985.

34. Wagner, J.; Sommer T.M.; Taylor, B.E.; and Johnson, S.A., "Coal-Water Mixture Firing in an Industrial Package Boiler -- A User's Perspective," Proceedings of the Seventh International Symposium on Coal Slurry Fuels Preparation and Utilization, New Orleans, LA, May 21-24, 1985, p. 734.

35. Astrand, L., and Rey, L.H., "CWM Demonstration at Sundbyberg," Sixth International Symposium on Coal Slurry Combustion and Technology, Orlando, FL, June 25-27, 1984, p. 541.

36. Carlsson, S.A., "The Sundbyberg Coal Water Fuel Fired Boiler - Experiences Gained between the 6th and 7th International Symposium on Coal Slurry Fuels," Proceedings of the Seventh International Symposium on Coal Slurry Fuels Preparation and Utilization, New Orleans, LA, May 21-24, 1985, p. 751.

37. Linder, G., and Rorgren, L., "Startup and Operating Experience of Three Commercial CWM Contracts in Sweden," Eighth International Symposium on Coal 
Slurry Fuels Preparation and Utilization, Orlando, FL, May 27-30, 1986, p. 933.

38. Stigsson, Lars L., "Fluidcarbon Fuel Production and Utilization in Sweden," Proceedings of the Seventh International Symposium on Coal Slurry Fuels Preparation and Utilization. New Orleans, LA, May 21-24, 1985, p. 951.

39. Miller, B.G. and Scaroni, A.W., "Penn State's Superciean Coal-Water Slurry Demonstration Project," Proceedings of the Seventeenth International Conference on Coal Utilization and Slurry Technologies, Clearwater, FL, April 28-May 1, 1992, p. 341.

40. Walsh, P.M.; Xie, J.; Elston, J.T.; Miller, B.G.; and Scaroni, A.W., "Erosion of Carbon Steel and Deposition of Particles under the Influence of High Velocity Jet Containing Fly Ash from Coal-Water Slurry Combustion," Seventeenth International Conference on Coal \& Slurry Technologies, Clearwater, FL, April 28-May 1, 1992, p. 561.

41. Farthing, G.A., and Markett, D.H., "Demonstration of B\&W $100 \mathrm{MBtu} / \mathrm{h}$ Burner for Coal-Water Slurry," Final Report, Electric Power Research Institute, Number CS-4808, September 1986.

42. Rini, M.J.; Marion, J.L.; and Lachowicz, Y.V., "Demonstration of the Combustion Engineering 100-MBtu/h Burner for Coal-Water Slurries, "Electric Power Research Institute, Final Report Number CS-4987, January 1987.

43. Ramachandran, P.; Scaroni, A.W.; and Jerikins, R.G., "Status of Commercially Available CWSF Burners and Atomizers in the U.S.," Proceedings of the Twelfth International Conference on Slurry Technology. New Orleans, LA, March 31-April 3, 1987, p. 107.

44. Ramachandran, P.; Scaroni, A.W.; and Jenkins, R.G., "Commercial Coal Water Slurry Fuel Burners and Atomizers," Proceedings of the Third European Conference, Malmo, Sweden, I. Chem E. Symposium Series No. 107, 1987. p. 219. 
45. Kiga, T.; Saitoh, H.; Miyamae, S.; Takahashi, K.; and Kataoka, T., "Combustion Technology of Coal Water Mixtures," Proceedings of the Seventh International Symposium on Coal Slurry Fuels Preparation and Utilization, New Orleans, LA, May 21-24, 1985, p. 631.

46. Toqan M.A.; Srinivasachar S.; Paloposki, T.; Loehoden, D.; Sayre, A.; and Beer, J.M., "Effects of Coal Fineness, Volatiles, and Mineral Matter Content on Carbon Burnout and Fly Ash in Coal Water Fuel Flames, "Proceedings of the Twelfth International Conference on Slurry Technology, New Orleans, LA, March 31-April 3, 1987, p. 31. 
TABLE 1. MAJOR COAL-WATER COMBUSTION EXPERIENCE AS OF 1970 (AFTER MARNELL [3])

\begin{tabular}{|c|c|c|c|c|c|}
\hline COUNTRY/PROJECT LOCATION & $\begin{array}{c}\text { WATER } \\
\text { CONTENT, \% } \\
\end{array}$ & $\begin{array}{c}\text { FUEL } \\
\text { TYPE/FORM } \\
\end{array}$ & $\begin{array}{l}\text { FUEL FLOW* } \\
1 \mathrm{~b} / \mathrm{hr}\end{array}$ & $\begin{array}{l}\text { STEAM RATE* } \\
\text { lb/hr }\end{array}$ & APPLICATION \\
\hline $\begin{array}{l}\text { USSR/Magnitororsk } \\
\text { Metallurgical Combine }\end{array}$ & 50 & $\begin{array}{l}\text { Coal Beneficiation } \\
\text { Wastes }\end{array}$ & 88,200 & 374,850 & Power Plant Boiler \\
\hline $\begin{array}{l}\text { USSR/Anzherskaya } \\
\text { Central Power Plant } \\
\end{array}$ & 45 & $\begin{array}{l}\text { Coal Beneficiation } \\
\text { Wastes }\end{array}$ & 17,640 & 88,200 & LMZ Boiler \\
\hline $\begin{array}{l}\text { USSR/Anzherskaya Central } \\
\text { Power Plant }\end{array}$ & 45 & $\begin{array}{l}\text { Coal Beneificiation } \\
\text { Wastes }\end{array}$ & 3,307 & 1,323 & $\begin{array}{l}\text { Spray Above Stoker- } \\
\text { Fired Boiler }\end{array}$ \\
\hline $\begin{array}{l}\text { USSR/Lutuginskaya- } \\
\text { Sevurnaya Mine } \\
\end{array}$ & Up to 50 & Wet Coal & 4,410 & $-\cdots$ & DKV Boiler \\
\hline $\begin{array}{l}\text { USSR/Zhilevskaya Plant, } \\
\text { Moscow Oblast }\end{array}$ & 40 & Coal-Water Mixture & 4,410 & ---- & Horizontal Cyclone \\
\hline USSR/Khigmavt & 40 & Coal Waste & 2,205 & -.-- & Cyclone \\
\hline USA/Werner Station, NJ & 30 & Coal-Water Mixture & 63,945 & 485,100 & Twin Cyclone Boiler \\
\hline $\begin{array}{l}\text { Germany/Kell larman } \\
\text { Lunar }\end{array}$ & 40 & Coal-Water Mixture & 44,100 & 220,500 & Pulverized-Coal Boiler \\
\hline
\end{tabular}

*These values were converted from metric ton ( 1 metric ton $=2,205 \mathrm{lb}$ ) 
TABLE 2. COAL-WATER FUEL COMBUSTION DEMONSTRATION PROJECTS

\begin{tabular}{|c|c|c|c|c|}
\hline $\begin{array}{l}\text { Country, } \\
\text { Project, MNe, [Ref.] }\end{array}$ & Project Sponsor & $\begin{array}{c}\text { Period of } \\
\text { Combustion Testing } \\
\end{array}$ & $\begin{array}{l}\text { Location of } \\
\text { Combustion Unit }\end{array}$ & Project Objective(s) \\
\hline $\begin{array}{l}\text { Japan } \\
\text { Nakoso } 8,600,[14,15]\end{array}$ & Fuyo Group of Companies & $\begin{array}{l}\text { (1) Burner Demo.: } \\
\text { June } 1986- \\
\text { March } 1987 \\
\text { (2) Part Use of CWF: } \\
\text { Feb. } 1988 \text { - Present }\end{array}$ & $\begin{array}{l}\text { Joban Joint Power Co. } \\
\text { Unit Nakoso } 18\end{array}$ & $\begin{array}{l}\text { (1) To demonstrate exclusive } \\
\text { firing potential of CWF. } \\
\text { establish burner for long- } \\
\text { term continuous operation, } \\
\text { and assess impact on } \\
\text { component life. (2) To } \\
\text { confirm and implement CWF for } \\
\text { partial use. }\end{array}$ \\
\hline $\begin{array}{l}\text { USA } \\
\text { Boston Edison, } 135,[5,16]\end{array}$ & Boston Edison, (Utility) & Nov. 1984 & $\begin{array}{l}\text { Mystic Station } \\
\text { No. } 4 \text { at Boston Edison }\end{array}$ & $\begin{array}{l}\text { To demonstrate manufacture, } \\
\text { shipment by barge, and } \\
\text { combustion of } 2100 \text { barrels of } \\
\text { low-ash CWF in effort to } \\
\text { convert an oil-designed unit } \\
\text { to CWF. }\end{array}$ \\
\hline $\begin{array}{l}\text { Italy } \\
\text { S. Barbara, 125. [17] }\end{array}$ & Government & 1982 & Santa Barbara & $\begin{array}{l}\text { To demonstrate that the } \\
\text { combustor designed for HFO or } \\
\text { coal could fire CWF after } \\
\text { burner modification. }\end{array}$ \\
\hline $\begin{array}{l}\text { USA } \\
\text { SCE\&G, 75, }[5,18]\end{array}$ & $\begin{array}{l}\text { Utility } \\
\text { (SCE\&G) }\end{array}$ & Jan. - April 1985 & $\begin{array}{l}\text { Urquhart Station } \\
\text { Beech Island, SC }\end{array}$ & $\begin{array}{l}\text { To confirm CWF production, } \\
\text { transportation, handling, and } \\
\text { combustion for utility } \\
\text { applications. }\end{array}$ \\
\hline $\begin{array}{l}\text { Japan } \\
\text { Nakoso 4, 75, [19] }\end{array}$ & Fuyo Group of Companies & Aug. 1985 to March 1986 & $\begin{array}{l}\text { Joban Joint Power Co.'s } \\
\text { Nakoso } 4 \text { Unit. Tokyo }\end{array}$ & $\begin{array}{l}\text { To demonstrate capability of } \\
\text { exclusive CWF firing, } \\
\text { maintain same combustion } \\
\text { operations as for oil/coal } \\
\text { fuels, and estimate component } \\
\text { life for long-term (> } 1000 \\
\text { hr) operation. }\end{array}$ \\
\hline
\end{tabular}


TABLE 2. COAL-WATER FUEL COMBUSTION DEMONSTRATION PROJECTS (continued)

\begin{tabular}{|c|c|c|c|c|}
\hline $\begin{array}{l}\text { Country, } \\
\text { Project, Mue, [Ref.] }\end{array}$ & Project Sponsor & $\begin{array}{c}\text { Period of } \\
\text { Combustion Testing }\end{array}$ & $\begin{array}{c}\text { Location of } \\
\text { Combustion Unit }\end{array}$ & Project Objective(s) \\
\hline $\begin{array}{l}\text { USA } \\
\text { Nerner, 60, }[20,21]\end{array}$ & Group of Companies & Oct. 1961 & $\begin{array}{l}\text { Werner Station } \\
\text { South Amboy, NJ }\end{array}$ & $\begin{array}{l}\text { To demonstrate feasibility of } \\
\text { transporting coal-based } \\
\text { liquid fuel by different } \\
\text { modes for combustion like } \\
\text { other liquid fuels. }\end{array}$ \\
\hline $\begin{array}{l}\text { Italy } \\
\text { S. Gilla, 35, }[23,24]\end{array}$ & $\begin{array}{l}\text { Governments of Italy and } \\
\text { U.S. }\end{array}$ & Nov. 1988 - May 1989 & Santa Gilla & $\begin{array}{l}\text { To demonstrate applicability } \\
\text { of CWF technology to oil- } \\
\text { designed boiler and evaluate } \\
\text { CWF fouling propensity. }\end{array}$ \\
\hline $\begin{array}{l}\text { Japan } \\
\text { Himeji, 33, [25] }\end{array}$ & Corporate & Oct. 1986 - Jan. 1987 & $\begin{array}{l}\text { Kansai Electric Co. } \\
\text { Himeji No. } 1\end{array}$ & $\begin{array}{l}\text { To gain experience with CWF } \\
\text { transportation, storage, and } \\
\text { combustion. }\end{array}$ \\
\hline $\begin{array}{l}\text { Japan } \\
\text { Idemitsu, 30.3, [11] }\end{array}$ & Government & August - Nov. 1990 & $\begin{array}{l}\text { Idemitsu Kosan's } \\
\text { Hokkaido Refinery }\end{array}$ & $\begin{array}{l}\text { To validate that low ash CWF } \\
\text { can be continuously used with } \\
\text { minimum modifications to the } \\
\text { existing plant and to } \\
\text { determine the extent of } \\
\text { necessary derating. }\end{array}$ \\
\hline $\begin{array}{l}\text { Canada } \\
\text { Charlottetown, 20, [27] }\end{array}$ & Government & Sept. 1986 - Sept. 1987 & $\begin{array}{l}\text { Charlottetown, Price } \\
\text { Edward Island }\end{array}$ & $\begin{array}{l}\text { To extend experience gained } \\
\text { from the Chatham } 11 \text { and } 12 \\
\text { Stations to a compact oil- } \\
\text { designed unit. }\end{array}$ \\
\hline $\begin{array}{l}\text { Canada } \\
\text { Chathan Sts.. (1) } 12 \text {, } \\
\text { (2) } 20, \text { [26] }\end{array}$ & Government & $\begin{array}{l}\text { Oct. - Nov. } 1983 \\
\text { June - Aug. } 1984 \\
\text { June - Nov. } 1984 \\
\end{array}$ & $\begin{array}{l}\text { Chatham Gen. Station, } \\
\text { New Brunswick }\end{array}$ & $\begin{array}{l}\text { To demonstrate feasibility } \\
\text { for CWF preparation and } \\
\text { combustion. }\end{array}$ \\
\hline $\begin{array}{l}\text { Korea } \\
\text { Yukong, 18.7, [28] }\end{array}$ & Corporate & Began March 1987 & $\begin{array}{l}\text { Yukong Ltd. } \\
\text { Refinery Site Ulsan }\end{array}$ & $\begin{array}{l}\text { To provide confidence in CWF } \\
\text { preparation and combustion } \\
\text { technologies for domestic } \\
\text { use. }\end{array}$ \\
\hline
\end{tabular}


TABLE 2. COAL-WATER FUEL COMBUSTION DEMONSTRATION PROJECTS (continued)

\begin{tabular}{|c|c|c|c|c|}
\hline $\begin{array}{l}\text { Country, } \\
\text { Project, Mue, [Ref.] }\end{array}$ & Project Sponsor & $\begin{array}{c}\text { Period of } \\
\text { Combustion Testing }\end{array}$ & $\begin{array}{c}\text { Location of } \\
\text { Combustion Unit }\end{array}$ & Project Objective(s) \\
\hline $\begin{array}{l}\text { China } \\
60 \text { tons/hr Unit, 15, [29] }\end{array}$ & Government & Dec. 1985 - Sept. 1987 & $\begin{array}{l}\text { Beijing First Paper } \\
\text { Mill's } 60 \text {-ton/hr Unit }\end{array}$ & $\begin{array}{l}\text { To extend experience from the } \\
20 \text { tons/hr unit to a larger } \\
\text { unit. To determine } \\
\text { suitability of axial swirling } \\
\text { register and confirm unit } \\
\text { operation. }\end{array}$ \\
\hline $\begin{array}{l}\text { USA } \\
\text { BEH NED, 8.1, [32] }\end{array}$ & Corporate & $\begin{array}{c}\text { Winters in } 1984-85 \\
1985-86\end{array}$ & BaW's NED Barberton, $\mathrm{OH}$ & $\begin{array}{l}\text { To develop confidence in } \\
\text { using CWF on an industrial } \\
\text { boiler. }\end{array}$ \\
\hline $\begin{array}{l}\text { USA } \\
\text { EPRI/Dupont, 7.5, [33] }\end{array}$ & EPRI & Aug. - Sept. 1983 & $\begin{array}{l}\text { Dupont } \mathrm{CO}_{0} \text { 's unit in } \\
\text { Memphis, iN }\end{array}$ & $\begin{array}{l}\text { To demonstrate and evaluate } \\
\text { procedures for procuring, } \\
\text { transporting, storing, and } \\
\text { firing CWF under practical } \\
\text { conditions and to prepare for } \\
\text { a long full-scale test. } \\
\end{array}$ \\
\hline $\begin{array}{l}\text { USA } \\
\text { Valleydale, 7.5, [34] }\end{array}$ & Corporate & Mov. 1984 & $\begin{array}{l}\text { Valleydale Packers } \\
\text { Production Plant } \\
\text { Bristol, VA }\end{array}$ & $\begin{array}{l}\text { To demonstrate the } \\
\text { feasibility of burning CWF in } \\
\text { an oil-designed boiler } \\
\text { without impacting unit } \\
\text { efficiency, emissions, and } \\
\text { operating personnel. }\end{array}$ \\
\hline $\begin{array}{l}\text { Sweden } \\
\text { Sundbyberg, 6.87, }[35,36]\end{array}$ & Government/Industry & $1984-85$ & $\begin{array}{l}\text { Sundbyberg Municipal } \\
\text { Dist. Heating Plant }\end{array}$ & $\begin{array}{l}\text { To demonstrate conversion of } \\
\text { an oil-designed boiler to CWF } \\
\text { combustion. }\end{array}$ \\
\hline $\begin{array}{l}\text { Sweden } \\
\text { Lund, 10, [37] }\end{array}$ & Government & Jan. 1983-1985 & $\begin{array}{l}\text { Lund Utility } \\
\text { Lund }\end{array}$ & $\begin{array}{l}\text { To demonstrate cormercial } \\
\text { feasibility of long-term CWF } \\
\text { use in a utility boiler. }\end{array}$ \\
\hline $\begin{array}{l}\text { Sweden, Commercial Cont. } \\
\text { (1) } 10 ; \text { (2) } 3.0 \\
\text { (3) } 2.5,[37,38]\end{array}$ & $\begin{array}{l}\text { Corporate } \\
\text { Colmercial } \\
\text { Contracts }\end{array}$ & $\begin{array}{l}\text { (1) Dec. } 1985-\mathrm{NA} \\
\text { (2) } 1985-\mathrm{NA} \\
\text { (3) } 1985-\mathrm{NA}\end{array}$ & $\begin{array}{l}\text { (1) Lund Utility } \\
\text { (2) Foodia AB } \\
\text { (3) SAB }\end{array}$ & $\begin{array}{l}\text { To establish and implement } \\
\text { CWF combustion technologies } \\
\text { in three commercial ventures } \\
\text { for long-term }(>1000 \mathrm{hr}) \\
\text { continuous use. }\end{array}$ \\
\hline
\end{tabular}


TABLE 2. COAL-WATER FUEL COMBUSTION DEMONSTRATION PROJECTS (continued)

\begin{tabular}{|c|c|c|c|c|}
\hline $\begin{array}{l}\text { Country, } \\
\text { Project, MNe, [Ref.] }\end{array}$ & Project Sponsor & $\begin{array}{c}\text { Period of } \\
\text { Combustion Testing }\end{array}$ & $\begin{array}{c}\text { Location of } \\
\text { Combustion Unit }\end{array}$ & Project Objective(s) \\
\hline $\begin{array}{l}\text { China } \\
20 \text { tons/hr Unit, } 5.5 \text {, } \\
{[30,31]}\end{array}$ & Government & Aug. $1984-1985$ & $\begin{array}{l}\text { Beijing First Paper } \\
\text { Mill's 20-ton/hr Unit }\end{array}$ & $\begin{array}{l}\text { To demonstrate feasibility of } \\
\text { CWF use after identifying } \\
\text { retrofit equipments for CWF } \\
\text { firing and gain experience in } \\
\text { CWF utilization. }\end{array}$ \\
\hline $\begin{array}{l}\text { USA } \\
\text { PSU, } 1.8,[8,39]\end{array}$ & Government & 1992- & $\begin{array}{l}\text { East Campus Steam } \\
\text { Plant, University Park, } \\
\text { PA }\end{array}$ & $\begin{array}{l}\text { To determine if a fuel } \\
\text { containing coal with less } \\
\text { than } 3 \text { wt\% ash and } 0.9 \text { wt: } \\
\text { sulfur, on a dry basis, can } \\
\text { be burned in oil-designed } \\
\text { industrial boilers without } \\
\text { adverse impact on boiler } \\
\text { performance. }\end{array}$ \\
\hline $\begin{array}{l}\text { USA } \\
\text { BAW Burner* [41] }\end{array}$ & EPRI & Oct. - Nov. 1984 & $\begin{array}{l}\text { Riley Research Furnace, } \\
\text { Horcester, } M \text { A }\end{array}$ & $\begin{array}{l}\text { To demonstrate } 100 \mathrm{MBtu} / \mathrm{hr} \\
\text { BaH burners for use in CWF } \\
\text { firing for boiler retrofits. }\end{array}$ \\
\hline $\begin{array}{l}\text { USA } \\
\text { ABB/CE Burner* [42] }\end{array}$ & EPRI & Oct. - Nov. 1985 & $\begin{array}{l}\text { ABB/CE's KDL Facility, } \\
\text { Windsor, CT }\end{array}$ & $\begin{array}{l}\text { To demonstrate } 100 \mathrm{MBtu} / \mathrm{hr} \\
\text { ABB/CE burner system for } \\
\text { long-term }(>100 \mathrm{hr}) \text { operation } \\
\text { and to confirm operation of } \\
\text { the burner according to EPRI- } \\
\text { established performance } \\
\text { criteria. }\end{array}$ \\
\hline
\end{tabular}

* Burner Demonstration Project at a test facility. 
APPEIDIX A. A CARONOLOGICAI IIST OF CONL-WRTER FUEL COWBUSTION Denonstration PROJECTs. - PAOE 1 OF 6

\begin{tabular}{|c|c|c|c|c|}
\hline $\begin{array}{l}\text { COUNTRY, } \\
\text { PROJECT, mide } \\
\text { [REF.] } \\
x=x=x=x=x=x=2=x=\end{array}$ & $\begin{array}{l}\text { PROJECT } \\
\text { SPONSOR }\end{array}$ & 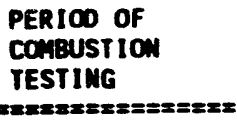 & $\begin{array}{l}\text { LOCATION OF } \\
\text { COnBustion } \\
\text { UNIT } \\
====== \pm===x=====\end{array}$ & 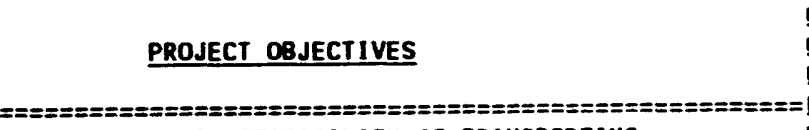 \\
\hline $\begin{array}{l}\text { USA } \\
\text { MERMER ST } \\
60[20,21]\end{array}$ & $\begin{array}{l}\text { CORPORATE } \\
\text { GROUP }\end{array}$ & СCT. 1961 & $\begin{array}{l}\text { MERNER STATION } \\
\text { SOUTH MMBOY, MJ }\end{array}$ & $\begin{array}{l}\text { TO DEMONSTRATE FEASIBILITY OF TRANSPORTING } \\
\text { A COAL-BASED LIOUID FUEL BY DIFFERENT MODES } \\
\text { FOR COHBUSTION LIKE OTHER LIOUID FUELS. }\end{array}$ \\
\hline $\begin{array}{l}\text { ITALY } \\
\text { S. BARBARA, } \\
125 \text { [17] }\end{array}$ & COVERMHENT & 1982 & SAMTA BARBARA & $\begin{array}{l}\text { TO DEMONSTRATE THAT THE COMBUSTOR } \\
\text { DESIGNED FOR HFO OR COAL COULD FIRE } \\
\text { CUF AFTER BURNER MODIFICATION. }\end{array}$ \\
\hline $\begin{array}{l}\text { SWEDEN } \\
\text { LUND UTILITY } \\
10 \text { [37] }\end{array}$ & COVERINENT & $\begin{array}{l}\text { JaN. } \\
1985\end{array}$ & $\begin{array}{l}\text { LUWD UTILITY } \\
\text { LUND }\end{array}$ & $\begin{array}{l}\text { TO DEMONSTRATE COMERCIAL FEASIBILITY } \\
\text { OF LONG-TERA CUF USE IN A UTILITY BOILER. }\end{array}$ \\
\hline $\begin{array}{l}\text { USA } \\
\text { EPRI/DLPONT } \\
7.5 \text { [33] }\end{array}$ & EPRI & $\begin{array}{l}\text { NUG.-SEPT. } \\
1983\end{array}$ & $\begin{array}{l}\text { DUPONT CO'S } \\
\text { UNIT IN } \\
\text { MEMPHIS, TM. }\end{array}$ & $\begin{array}{l}\text { TO DEMONSTRATE AMO EVALUATE PROCEDURES } \\
\text { FOR PROCURING, TRANSPORTING, STORING, } \\
\text { AND FIRING CWF UNDER PRACTICAL } \\
\text { COWDITIONS AWD TO PREPARE FOR A LONG } \\
\text { FULL-SCALE TEST. }\end{array}$ \\
\hline $\begin{array}{l}\text { CAMUDA } \\
\text { CH STS, } 1112.5 \\
1222.5[5.26]\end{array}$ & COVERMEENT & $\begin{array}{l}\text { OCT. - NOW. } 1983 \\
\text { JUNE-AWG. } 1984 \\
\text { JUNE-NOV. } 1984\end{array}$ & $\begin{array}{l}\text { CHATHAM GEM. } \\
\text { STATIOUS, MEU } \\
\text { BRUUSWICK }\end{array}$ & $\begin{array}{l}\text { TO DEMONSTRATE FEASIBILITY FOR } \\
\text { CUF PREPARATION AND COMBUSTION. }\end{array}$ \\
\hline
\end{tabular}


APPEADIX A. (CONIIMULD): PAGS 2 OF 6

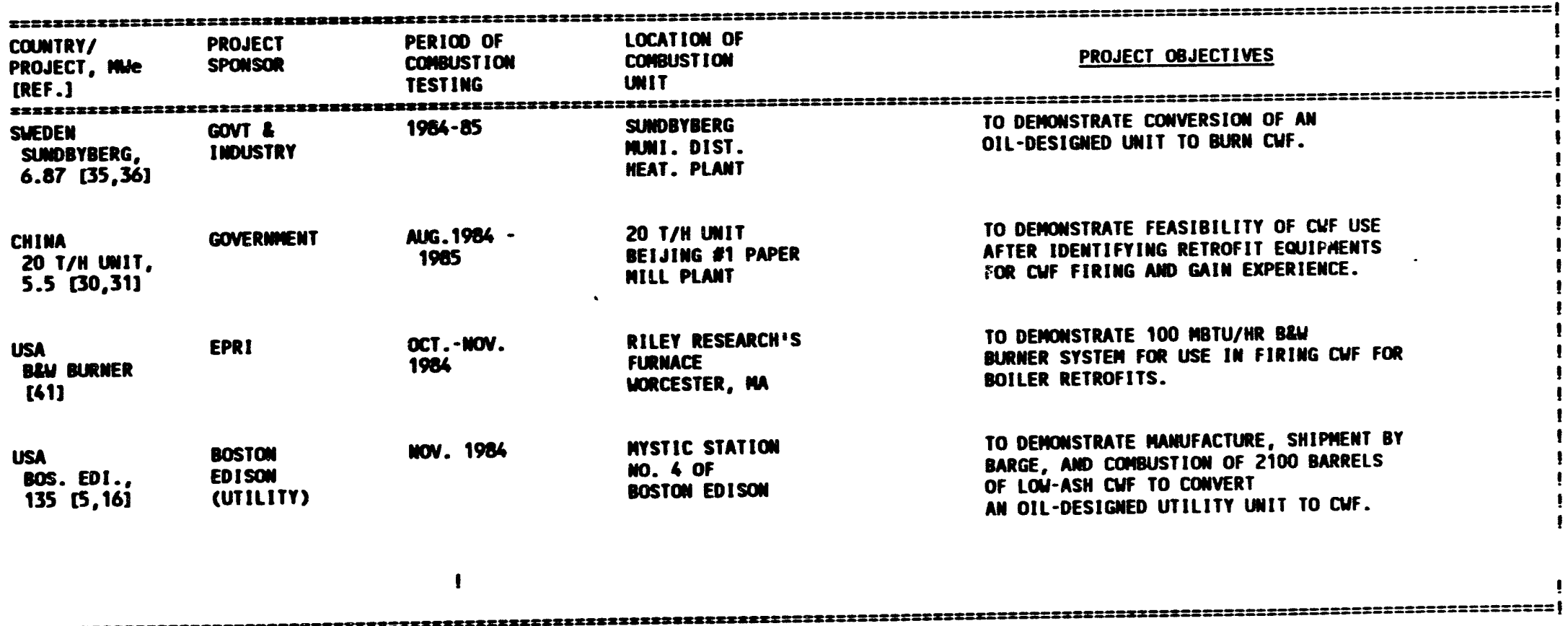


APPEADIX A. (CONIIMUTD): PAGS 3 or 6

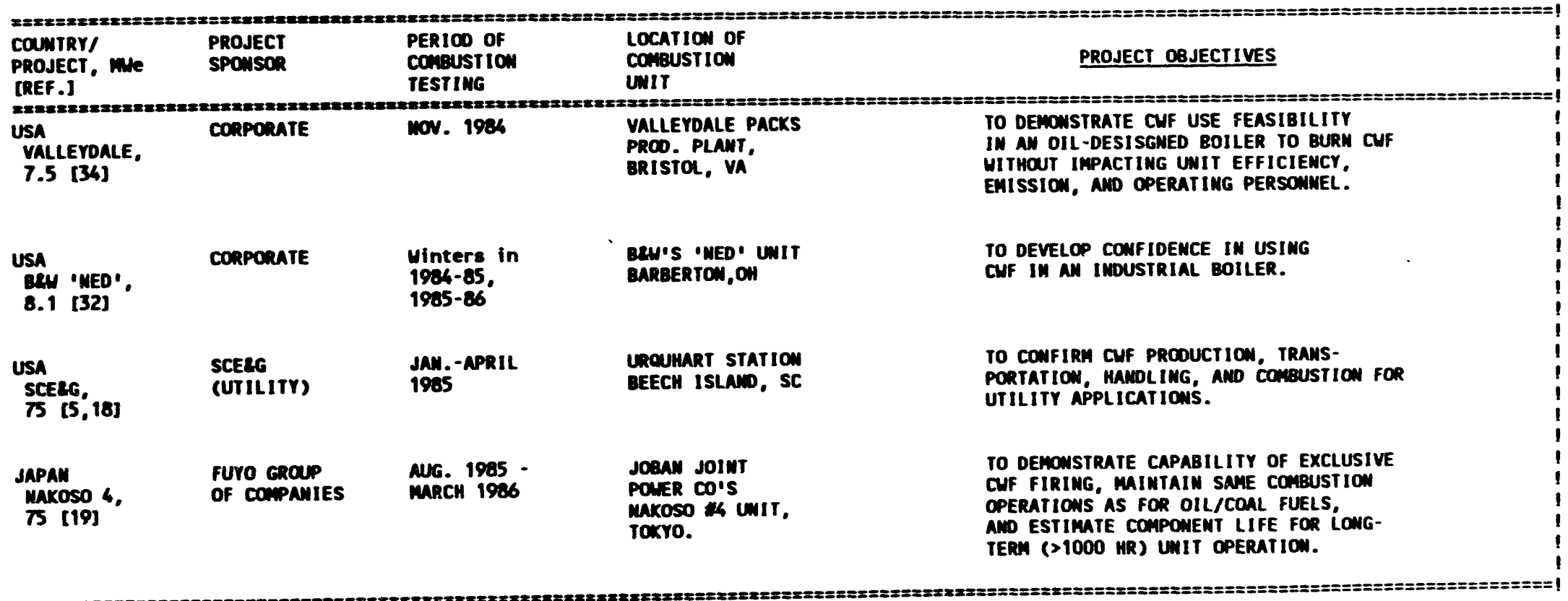


APPEIDIX A. (CONIINUED); PAGS A OF 6

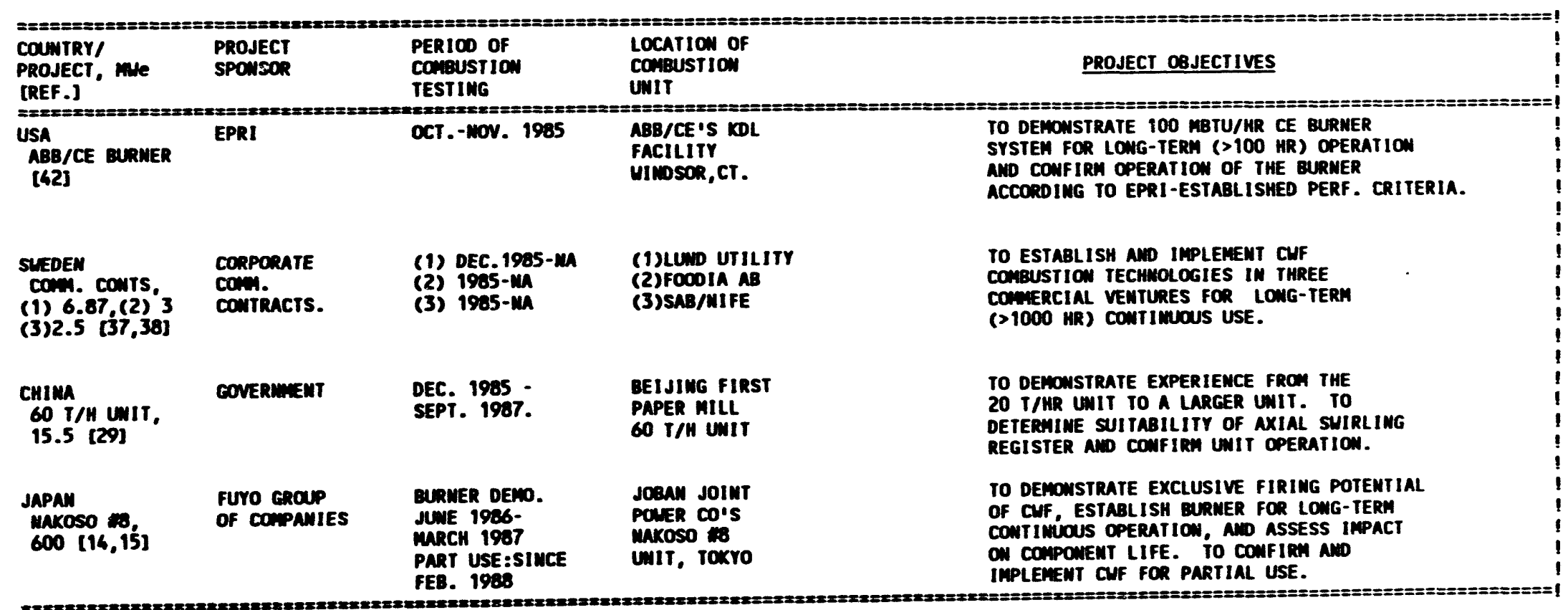


APPEIDIX A. (COMPINUED); PAOE 5 OF 6

\begin{tabular}{|c|c|c|c|c|}
\hline $\begin{array}{l}\text { COWWTRY, } \\
\text { PROJECT, mie } \\
\text { [REF.] }\end{array}$ & $\begin{array}{l}\text { PROJECT } \\
\text { SPOUSOR }\end{array}$ & $\begin{array}{l}\text { PERIOD OF } \\
\text { COMBUSTION } \\
\text { TESTIMG } \\
\end{array}$ & 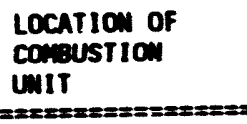 & $\begin{array}{l}\text { PROJECT Q8JECTIVES } \\
\text { P. }\end{array}$ \\
\hline $\begin{array}{l}\text { CAMADA } \\
\text { CHARLTIN, } 20\end{array}$ & COVERIMENT & $\begin{array}{l}\text { SEPT. } 1906- \\
\text { SEPT. } 1907\end{array}$ & 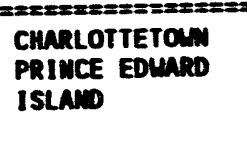 & 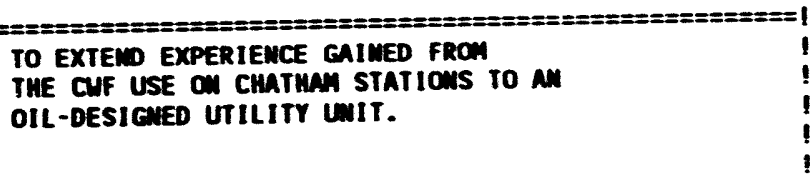 \\
\hline 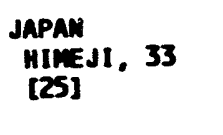 & $\begin{array}{l}\text { furo croup } \\
\text { of companies }\end{array}$ & $\begin{array}{l}\text { oct. } 1986 \text { - } \\
\text { JAI. } 1987\end{array}$ & $\begin{array}{l}\text { KAMSAI ELEC Co. } \\
\text { HIMEdI wo. } 1\end{array}$ & $\begin{array}{l}\text { TO GAIN EXPERIENCE HITH CUF } \\
\text { TRAMSPORTATION, STORAGE, AND } \\
\text { COMBUSTIOH. }\end{array}$ \\
\hline $\begin{array}{l}\text { KOREA } \\
\text { YUKONG, } \\
18.7 \text { [26] }\end{array}$ & CORPORATE & $\begin{array}{l}\text { BECAM MARCM } \\
\text { 1987- }\end{array}$ & $\begin{array}{l}\text { YUKONG LTD.'S } \\
\text { REFIMERY SITE, } \\
\text { ULSAW }\end{array}$ & $\begin{array}{l}\text { TO PRONIDE CONFIDENCE IN CUF PREPARATION } \\
\text { AND COMBUSTIOW TECMMOLOGIES FOR } \\
\text { DONESTIC USE. }\end{array}$ \\
\hline $\begin{array}{l}\text { ITALY } \\
\text { S. GILLA, } 35 \\
{[23,26]}\end{array}$ & $\begin{array}{l}\text { ITALY ANO U.S. } \\
\text { GOVER,WIEMTS }\end{array}$ & $\begin{array}{l}\text { MOV. } 1988 \text { - } \\
\text { MAY } 1909\end{array}$ & $\begin{array}{l}\text { SAmTA GILLA } \\
\text { UNIT } \mathbb{R}^{2} \text {. }\end{array}$ & $\begin{array}{l}\text { TO DEMONSTRATE APPLICABILITY OF CUF } \\
\text { TECMMOLOGY TO OIL-DESIGEE BOILER ANO } \\
\text { EVALUATE CUF FOULING PROPEMSITY. }\end{array}$ \\
\hline
\end{tabular}


APPEADIX A. (CONTIMUSD); RAOS 6 OF 6

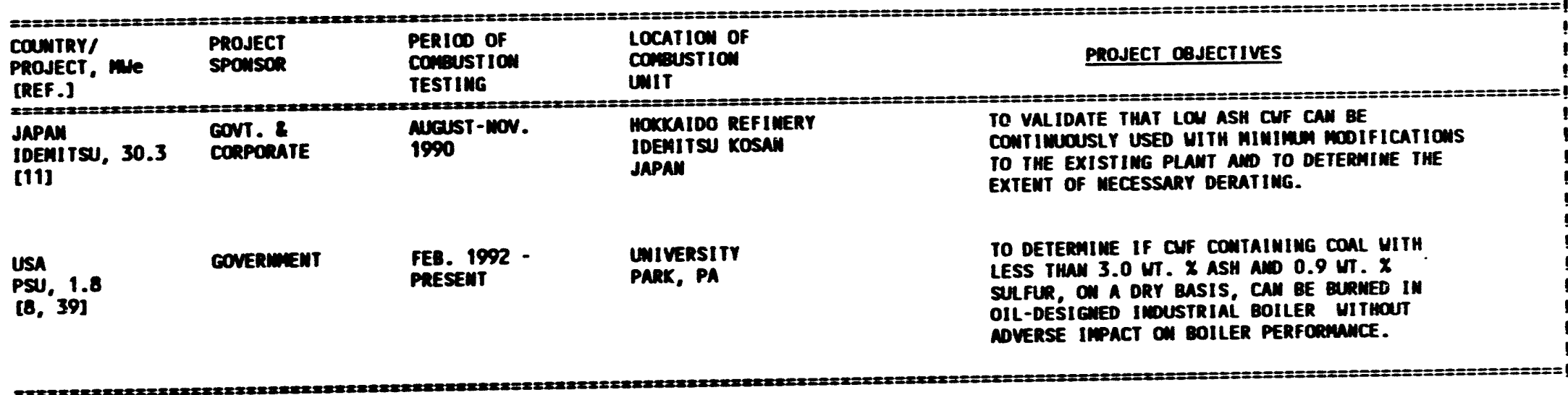


APPEADIX B. BPECIFICNTIOAB OF IHS BOILER UIITS UBED FOR CWF COABUSTIOA

DEnonstration phovecrs. pags 1 or 5

\begin{tabular}{|c|c|c|c|c|c|c|c|c|c|c|c|}
\hline 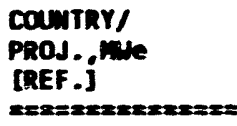 & 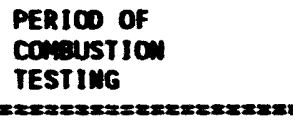 & $\begin{array}{l}\text { Location of } \\
\text { comistion } \\
\text { Uili } \\
\text { and }\end{array}$ & 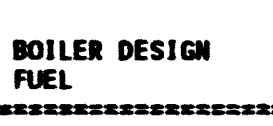 & $\begin{array}{l}\text { INPUT } \\
\text { RATE } \\
\text { (LB/MR) } \\
x=x= \pm=x=\end{array}$ & $\begin{array}{l}\text { USE US } \\
\text { LENGTH } \\
\text { LETH }\end{array}$ & $\begin{array}{l}\text { SED } \\
\text { TOTAL } \\
\text { OTY. } \\
\text { P=T=: }\end{array}$ & $\begin{array}{l}\text { BOILER } \\
\text { RATIMG } \\
\text { Mue }\end{array}$ & 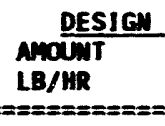 & $\begin{array}{l}\text { STEAM LOAD } \\
\text { PRESSURE } \\
\text { PSI } \\
========\end{array}$ & $\begin{array}{l}\text { TENP. } \\
\text { DEG. F }\end{array}$ & $\begin{array}{l}\text { STEAH LOND } \\
\text { DURING CWF } \\
\text { FIRIMG (Ib/hr) } \\
====\end{array}$ \\
\hline $\begin{array}{l}\text { JAPAM } \\
\text { MAKOSO } \\
600 \\
{[14.15]}\end{array}$ & $\begin{array}{l}\text { (1)BURMER DEMO. } \\
\text { JUME } 1906 \text { - MARCH } \\
1987 \text { (2) PART USE } \\
\text { FEB. 1908-PRESENT }\end{array}$ & $\begin{array}{l}\text { JOBAN JOINT } \\
\text { PONER CO.. } \\
\text { TOKYY, } \\
\text { MAKOSO } 10\end{array}$ & $\begin{array}{l}\text { COAL AN OIL } \\
\text { UNIT WITH MULTI- } \\
\text { FUEL CAPABILIIT }\end{array}$ & $\cdots$ & $\begin{array}{l}\text { (1) } 2000 \\
\text { MRS. } \\
(2)>1 \mathrm{YR} \text {. }\end{array}$ & $\begin{array}{l}\text { (1) } \cdots \\
\text { (2) } 70,000 \\
\text { TOUS/YR }\end{array}$ & 600 & $4.2 n$ & 3620 & 1009 & $\begin{array}{l}100 x \\
\text { Rating }\end{array}$ \\
\hline $\begin{array}{l}\text { USA } \\
\text { BOSTON } \\
\text { ED ISON, } 135 \\
{[5,16]}\end{array}$ & nov. $19 a 4$ & $\begin{array}{l}\text { mrstic station } \\
\text { Mo in } \mathrm{M} \text {. }\end{array}$ & OIL & 3,500 & 10 DAYs & $\begin{array}{l}400 \\
\text { TONS }\end{array}$ & 135 & 935,000 & 1970 & 1000 & $\cdots$ \\
\hline $\begin{array}{l}\text { IIALY } \\
\text { SAMTA } \\
\text { BARBARA, } 125 \\
\text { [I7] }\end{array}$ & 1982 & $\begin{array}{l}\text { One of two } \\
125 \text { inte Units. }\end{array}$ & $\begin{array}{l}\text { OIL \& COAL } \\
\text { CUF FIRED } \\
\text { MITH OIL }\end{array}$ & $\begin{array}{l}1980- \\
-7700\end{array}$ & 25 MRS & $\begin{array}{l}20 \\
\text { Tous }\end{array}$ & 125 & - & $\cdots$ & $\cdots$ & $\begin{array}{l}60 x \\
\text { Rating }\end{array}$ \\
\hline $\begin{array}{l}\text { USA } \\
\text { SCEEG, } 75 \\
{[5,18]}\end{array}$ & $\begin{array}{l}\text { JAM.-APRIL } \\
1905\end{array}$ & $\begin{array}{l}\text { S. CAROLIMA } \\
\text { ELEC.\& EAS, } \\
\text { BEECH ISLAID }\end{array}$ & $\begin{array}{l}\text { COAL. } \\
\text { INIT OF } \\
\text { ABB/CE DESIGN }\end{array}$ & 9,357 & 368 MRS & $\begin{array}{l}942 \text { TOus } \\
\text { (SHORT) }\end{array}$ & 75 & -- & - & 1005 & -. \\
\hline
\end{tabular}




\section{APPEADIX B. (COIMIMUED); PACS 2 OF 5}

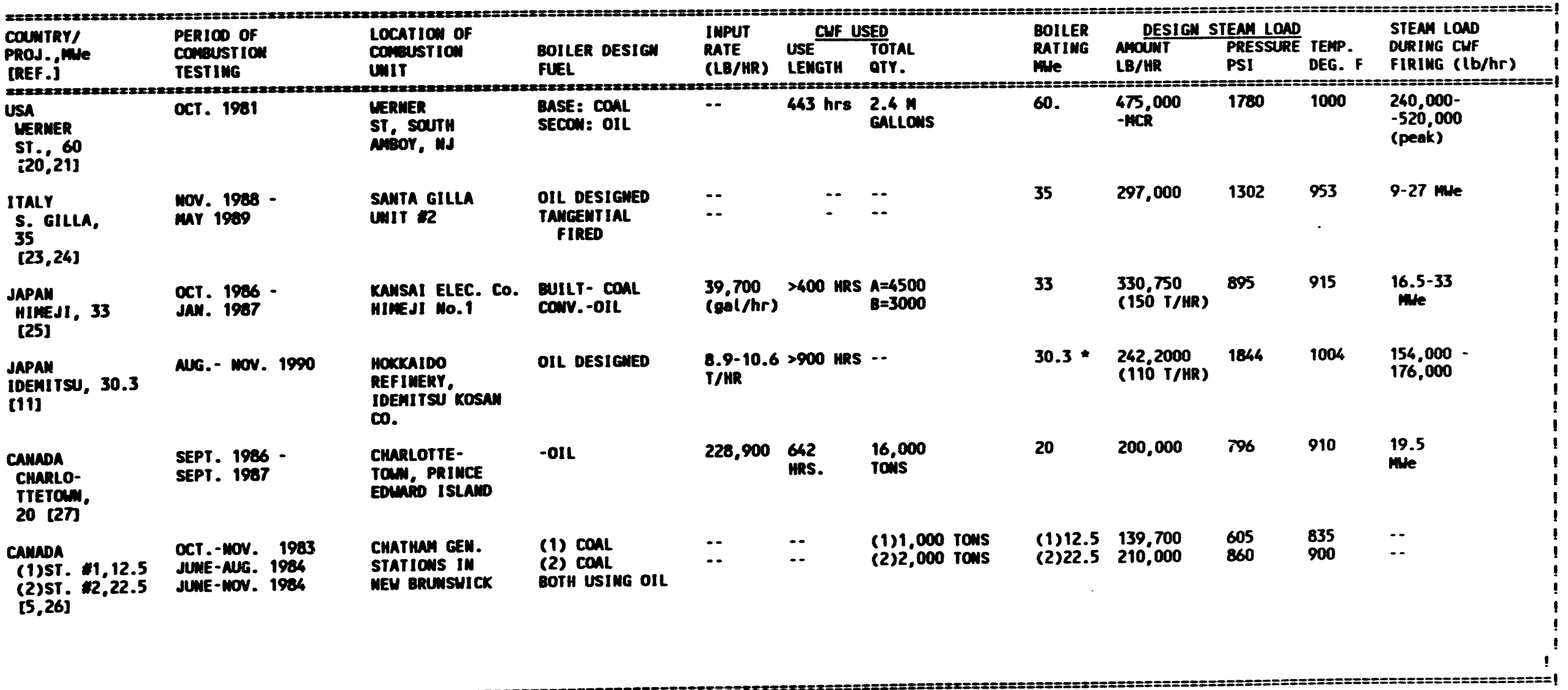

- the mue rating mas calculated based on the data provided for a trpical case by ratafia-brom [9]. 


\section{APPEIDIX B. (CONTINUED); PAOE 3 OF 5}

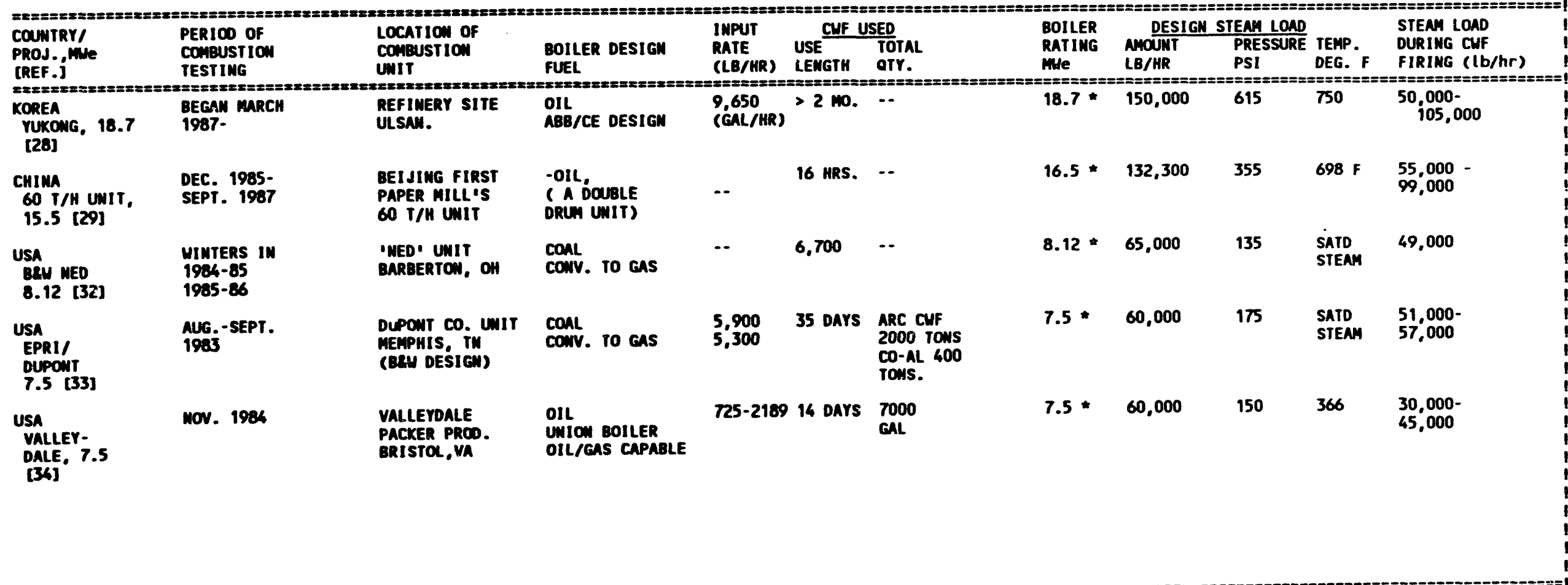

\footnotetext{
- the me rating mas calculated based on the data provided for a typical case by ratafia-brom [9].
} 
APPEDIX B. (CONTINUTD): PLes 4 or 5

\begin{tabular}{|c|c|c|c|c|c|c|c|c|c|c|c|}
\hline 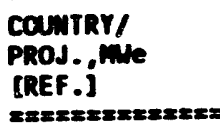 & $\begin{array}{l}\text { PERIOD OF } \\
\text { CONBUSTIOW } \\
\text { TESTIMG } \\
x=x=x=x= \pm x=x=x=2\end{array}$ & 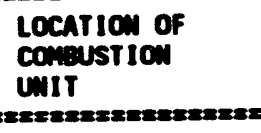 & $\begin{array}{l}\text { BOILER DESIGW } \\
\text { FUEL } \\
x=x=x=x=x=x=x=x\end{array}$ & $\begin{array}{l}\text { IMPUT } \\
\text { RATE } \\
\text { (LB/HR) } \\
\text { Ex=:=E=E=: }\end{array}$ & $\begin{array}{l}\text { CUF US } \\
\text { USE } \\
\text { LENGTH }\end{array}$ & 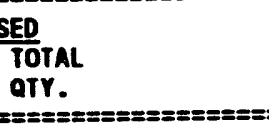 & 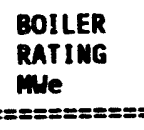 & $\begin{array}{l}\text { DESIGN STE } \\
\text { LB/HR } \\
\text { LBWT }\end{array}$ & $\begin{array}{l}\frac{\text { IEAM LOAD }}{\text { PRESSURE }} \\
\text { PS1 } \\
========\end{array}$ & $\begin{array}{l}\text { TEMP. } \\
\text { DEG. F }\end{array}$ & $\begin{array}{l}\text { SIEAH LOAD } \\
\text { DURING CUF } \\
\text { FIRING (ib/hr) } \\
==:==:====:===\end{array}$ \\
\hline $\begin{array}{l}\text { SUEDEA } \\
\text { SUMDBYBERG, } \\
6.87 \\
{[35,36]}\end{array}$ & $1984-85$ & $\begin{array}{l}\text { SUMBYBERG } \\
\text { MUNI. DIST. } \\
\text { MEATING UNIT }\end{array}$ & $\begin{array}{l}\text { OIL, BUILT BY } \\
\text { SVEISSKA MASKIN- } \\
\text { VENKEN, SWEDEN }\end{array}$ & $\begin{array}{l}3500- \\
--5500\end{array}$ & 1500 MRS & $\begin{array}{l}2500 \\
\text { TONS }\end{array}$ & 6.87 & 51,000 & 780 & $900 \mathrm{~F}$ & 37,000 \\
\hline $\begin{array}{l}\text { SUEDEN } \\
\text { LUVD } \\
\text { UTILITY, } \\
10[37]\end{array}$ & $\begin{array}{l}\text { JaM. } \\
\text { 1985 }\end{array}$ & $\begin{array}{l}\text { LUWD UTILITY } \\
\text { LUW. }\end{array}$ & $\begin{array}{l}\text {-OIL, ECKROHR } \\
\text { DESIGNED } \\
\text { MATERTUBE UNIT }\end{array}$ & $\cdots$ & $\begin{array}{l}11000 \\
\text { MRS. }\end{array}$ & $\begin{array}{l}8000 \\
\text { TOWS }\end{array}$ & 29 mut & $\cdots$ & -- & $\cdots$ & 4-20 MHt \\
\hline $\begin{array}{l}\text { SUEDEN } \\
\text { CONA. } \\
\text { CONTCS. } \\
\text { [37,38] }\end{array}$ & $\begin{array}{l}\text { (1) DEC. } 1985-\mathrm{MA} \\
\text { (2) } 1905-\mathrm{NA} \\
\text { (3) } 1985-\mathrm{NA}\end{array}$ & $\begin{array}{l}\text { (1)LUND UTILITY } \\
\text { (2)FOODIA AB } \\
\text { (3) SAB NIFE } \\
\text { - FIRE TUBE }\end{array}$ & $\begin{array}{l}\text { (1) OIL } \\
\text { (2) OIL } \\
\text { (3) OIL }\end{array}$ & $\begin{array}{l}-- \\
--\end{array}$ & $\begin{array}{l}\cdots \\
\cdots \\
--\end{array}$ & 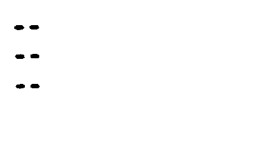 & $\begin{array}{l}29 \mathrm{mt} \\
3.12 * \\
2.5\end{array}$ & $\begin{array}{l}27,500 \\
22,000\end{array}$ & $\begin{array}{l}\cdots \\
348 \\
174\end{array}$ & $\begin{array}{l}-- \\
\text { SATD. } \\
\text { SATD. }\end{array}$ & $\begin{array}{l}4-20 \mathrm{mit} \\
13,200-19,800 \\
9,900-13,200\end{array}$ \\
\hline $\begin{array}{l}\text { CHImA } \\
20 \text { T/n UNIT } \\
5.5[30,31]\end{array}$ & $\begin{array}{l}\text { AUE. 1984- } \\
1905\end{array}$ & $\begin{array}{l}20 \text { T/MR UNIT AT } \\
\text { BEIJIMG FIRST } \\
\text { PAPER MILL. }\end{array}$ & $-\operatorname{conl}$ roIL & 8,300 & 26 MRS & $\begin{array}{l}2320 \\
\text { TOMS }\end{array}$ & $5.5 *$ & $\begin{array}{l}44,100(\mathrm{PC}) \\
55,125 \text { (oil) }\end{array}$ & $\begin{array}{r}185 \\
, 155\end{array}$ & $\begin{array}{l}\text { SATD. } \\
-.\end{array}$ & $\begin{array}{l}\text { UPIO } 1.5 \\
\text { TIMES } \\
\text { RATING }\end{array}$ \\
\hline $\begin{array}{l}\text { USA } \\
\text { PSU, } 1.8 \\
{[8,39]}\end{array}$ & $\begin{array}{l}\text { FEB. } 1992- \\
\text { PRESENT. }\end{array}$ & $\begin{array}{l}\text { UNIVERSITY } \\
\text { PARK, PA }\end{array}$ & $\begin{array}{l}\text { OIL DESIGNED } \\
\text { (GAS FIRED) }\end{array}$ & $\begin{array}{l}1,600 \\
70 x \\
\text { THERMAL } \\
\text { INPUT } \\
\text { CO-FIRED } \\
\text { UITH GAS } \\
\text { (FIRST DE }\end{array}$ & $\begin{array}{l}500 \text { MRS } \\
\text { TIL } \\
\text { OCT.92 } \\
\\
\text { EMO.) }\end{array}$ & $\begin{array}{l}400 \text { SHORT TONS } \\
\text { (FIRST DEMO.) } \\
1100 \text { SHORT TONS } \\
\text { (SECOMD DEMO.) }\end{array}$ & $x .8 *$ & 15,000 & 300 & SATD. & $\begin{array}{l}9,500- \\
15,000\end{array}$ \\
\hline
\end{tabular}

\footnotetext{
- the me rating mas calculated based on the data provided for a trpical case by ratafia-broun [9].
} 
APPENDIX B. (CONMINUED): PAOS 5 OF 5

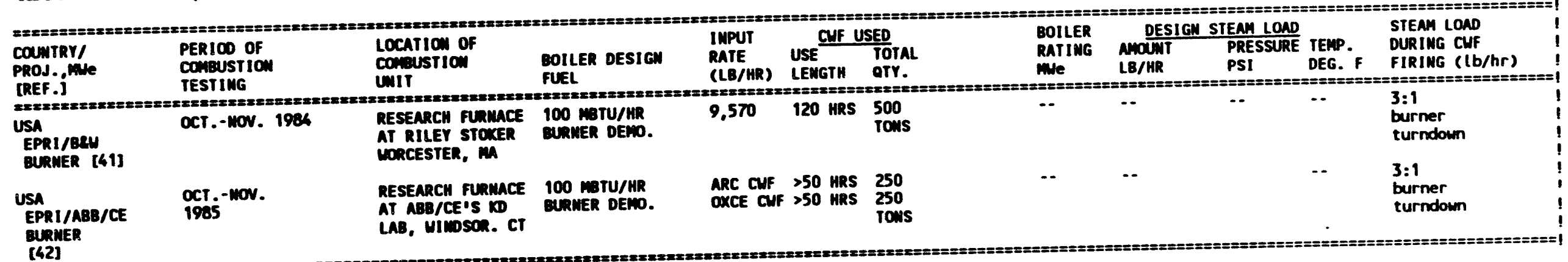

- the me ratimg uns calculated based on the data provided for a trpical case by ratafia-brom [9]. 
APPEDIX C. PROIINATS ANAY8ES OF FUEL USED FOR THE COAL-WATER FUEL COWBUSTION

\begin{tabular}{|c|c|c|c|c|c|c|c|c|c|c|}
\hline $\begin{array}{l}\text { COUNTRY } \\
\text { PROJ. } \\
\text { MUe, [REF] } \\
=x=x=x=x=m=x\end{array}$ & 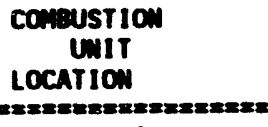 & $\begin{array}{l}\text { FUEL } \\
\text { FORM }\end{array}$ & conl & $\begin{array}{l}\text { SOURCE } \\
\text { ID }\end{array}$ & $\begin{array}{l}\text { MOI- } \\
\text { STURE } \\
x \\
=====0\end{array}$ & $\begin{array}{l}\text { VOL. } \\
\text { Mait. } \\
x \\
\text { a=s=:==: }\end{array}$ & $\begin{array}{l}\text { FIX } \\
\text { CARB } \\
X \\
======\end{array}$ & $\begin{array}{l}\text { ASH } \\
x \\
======\end{array}$ & $\begin{array}{l}\text { TOTAL } \\
\text { SULFUR } \\
x \\
======\end{array}$ & $\begin{array}{l}\text { HEAT VALUE } \\
\text { BTU/LB } \\
===========\end{array}$ \\
\hline $\begin{array}{l}\text { JAPAM } \\
\text { MAKOSO } \%, \\
600 \\
{[16,15]}\end{array}$ & $\begin{array}{l}\text { Joban Joint } \\
\text { Power Co.'s } \\
\text { Unit Wakoso to } \\
\text { Tokyo }\end{array}$ & conl & $\begin{array}{l}\text { Type \& } \\
\text { Source } \\
\text { Mot } \\
\text { avail- } \\
\text { able. }\end{array}$ & $\begin{array}{l}C \\
F \\
11 \\
12 \\
B \\
\text { MIXED }\end{array}$ & $\begin{array}{l}2.9 \\
3.1 \\
5.4 \\
5.9 \\
8.8 \\
6.7\end{array}$ & $\begin{array}{l}30.9 \\
30.7 \\
43.2 \\
35.4 \\
23.4 \\
34.0\end{array}$ & $\begin{array}{l}52.5 \\
51.5 \\
38.4 \\
30.4 \\
57.7 \\
42.8\end{array}$ & $\begin{array}{l}13.8 \\
14.7 \\
13.0 \\
28.3 \\
8.1 \\
16.5\end{array}$ & $\begin{array}{l}0.43 \\
0.51 \\
0.21 \\
0.22 \\
0.23 \\
0.22\end{array}$ & $\begin{array}{l}12,320 \\
11.790 \\
11.250 \\
10,709 \\
11.790 \\
10,700\end{array}$ \\
\hline $\begin{array}{l}\text { USA } \\
\text { BOS.ED... } \\
135 \\
{[5,16]}\end{array}$ & $\begin{array}{l}\text { Mystic Station } \\
\text { Mo. } 4 \text { at } \\
\text { Boston Edison }\end{array}$ & $\begin{array}{l}\text { COAL } \\
\text { CNF }\end{array}$ & $\begin{array}{l}\text { Koppers } \\
\text { Koppers }\end{array}$ & & $\begin{array}{l}2.6 \\
30.1\end{array}$ & $\begin{array}{l}33.0 \\
22.37\end{array}$ & $\begin{array}{l}64.3 \\
45.64\end{array}$ & $\begin{array}{l}2.8 \\
1.8\end{array}$ & $\begin{array}{l}0.64 \\
0.79\end{array}$ & $\begin{array}{l}15,000 \\
10,849\end{array}$ \\
\hline $\begin{array}{l}\text { ITALY } \\
\text { S. BARBARA, } \\
125 \text { [17] }\end{array}$ & Santa Barbara & COAL & & $\begin{array}{l}\mathbf{A} \\
\mathbf{B} \\
\mathbf{C}\end{array}$ & $\begin{array}{l}0.00 \\
0.00 \\
0.00\end{array}$ & $\begin{array}{l}32 \\
23 \\
17\end{array}$ & $\begin{array}{l}56 \\
62 \\
66\end{array}$ & $\begin{array}{l}12 \\
15 \\
17\end{array}$ & $\begin{array}{l}-- \\
--\end{array}$ & $\begin{array}{l}11.430 \\
11.791 \\
12,679\end{array}$ \\
\hline $\begin{array}{l}\text { USA } \\
\text { SCER, } 75 \\
{[5,18]}\end{array}$ & $\begin{array}{l}\text { Urquhart Station } \\
\text { sCELG } \\
\text { Beech Island, SC }\end{array}$ & $\begin{array}{l}\operatorname{conl} \\
\operatorname{conl} \\
\operatorname{conl}\end{array}$ & $\begin{array}{l}\text { Brownie } \\
\text { vicc } \\
\text { Vell Inor }\end{array}$ & Creek & $\begin{array}{l}2.98 \\
2.84 \\
6.59\end{array}$ & $\begin{array}{l}33.01 \\
36.10 \\
29.92\end{array}$ & $\begin{array}{l}52.90 \\
54.68 \\
57.64\end{array}$ & $\begin{array}{l}11.11 \\
6.38 \\
5.85\end{array}$ & $\begin{array}{l}1.33 \\
1.13 \\
0.92\end{array}$ & $\begin{array}{l}13,324 \\
14,100 \\
14,498\end{array}$ \\
\hline
\end{tabular}




\begin{tabular}{|c|c|c|c|c|c|c|c|c|c|c|c|}
\hline 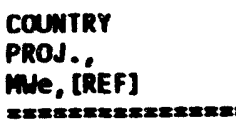 & $\begin{array}{l}\text { COMUUSTION } \\
\text { UNIT } \\
\text { LOCATIOH }\end{array}$ & $\begin{array}{l}\text { FUEL } \\
\text { FOPH } \\
\end{array}$ & 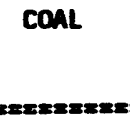 & $\begin{array}{l}\text { SOURCE } \\
\text { ID } \\
\end{array}$ & $\begin{array}{l}\text { MOI- } \\
\text { STURE } \\
x \\
x=x=x\end{array}$ & $\underset{x}{\text { VOL. }} \underset{x}{\text { MIT. }}$ & $\begin{array}{l}F I X \\
\text { CARB } \\
x \\
x====\end{array}$ & $\begin{array}{l}\text { ASH } \\
\mathbf{X} \\
======\end{array}$ & $\begin{array}{l}\text { TOTAL } \\
\text { SULFUR } \\
x \\
======\end{array}$ & $\begin{array}{l}\text { HEAT VALUE } \\
\text { BTU/LB } \\
\text { :======="===" }\end{array}$ & $=======1$ \\
\hline $\begin{array}{l}\text { JAPAN } \\
\text { MaKOSO } 14, \\
75 \\
{[19]}\end{array}$ & $\begin{array}{l}\text { Joben Joint Power } \\
\text { Co.'s Unit: } \\
\text { Nakoso }\end{array}$ & conl & $\begin{array}{l}\text { Not } \\
\text { Avail- } \\
\text { oble }\end{array}$ & $\begin{array}{l}\hat{A} \\
\mathbf{B} \\
\mathbf{C} \\
\mathbf{D} \\
\mathbf{E}\end{array}$ & $\begin{array}{l}5.8 \\
3.5 \\
2.5 \\
2.7 \\
4.9\end{array}$ & $\begin{array}{l}42.9 \\
29.4 \\
30.0 \\
25.8 \\
41.5\end{array}$ & $\begin{array}{l}35.5 \\
50.8 \\
52.5 \\
57.5 \\
45.6\end{array}$ & $\begin{array}{l}15.8 \\
16.3 \\
15.0 \\
14.0 \\
8.0\end{array}$ & $\begin{array}{l}0.3 \\
0.45 \\
0.6 \\
0.5 \\
0.8\end{array}$ & $\begin{array}{l}10.261 \\
11.053 \\
11.557 \\
11.575 \\
11.701\end{array}$ & $!$ \\
\hline $\begin{array}{l}\text { USA } \\
\text { MERMER ST.. } \\
60[21,22]\end{array}$ & $\begin{array}{l}\text { Werner Station, } \\
\text { South Aboy. MJ }\end{array}$ & anf & Washed & thio & 33.0 & 28.0 & 34.0 & 5.0 & 1.9 & 9,090 & ! \\
\hline $\begin{array}{l}\text { ITALY } \\
\text { S. GILLA, } 35 \\
{[23,26]}\end{array}$ & Sante Gille & $\underset{\text { CNF }}{\text { CNF }}$ & $\begin{array}{l}\text { Mapco C } \\
\text { McCall }\end{array}$ & Coal & $\begin{array}{l}33.9 \\
33.4\end{array}$ & $\begin{array}{l}21.9 \\
19.5\end{array}$ & $\begin{array}{l}39.7 \\
42.8\end{array}$ & $\begin{array}{l}4.5 \\
4.4\end{array}$ & $\begin{array}{l}0.6 \\
0.7\end{array}$ & $\begin{array}{l}9,090 \\
9.324\end{array}$ & $\begin{array}{l}\vdots \\
\vdots \\
1\end{array}$ \\
\hline$\underset{\substack{\text { MIMEJ JI, } \\
\text { [25] }}}{\text { JAPAM }}$ & $\begin{array}{l}\text { Ransei Elec. Co. } \\
\text { Himeji HI }\end{array}$ & $\operatorname{con} L$ & $\begin{array}{l}\text { Not } \\
\text { Avail. }\end{array}$ & $\begin{array}{l}\mathbf{A} \\
\mathbf{B}\end{array}$ & $\begin{array}{l}1.8 \\
6.4\end{array}$ & $\begin{array}{l}22.4 \\
43.9\end{array}$ & $\begin{array}{l}58.3 \\
37.6\end{array}$ & $\begin{array}{l}17.5 \\
12.1\end{array}$ & 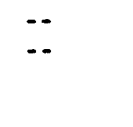 & $\begin{array}{l}12,020 \\
12,170\end{array}$ & $\begin{array}{l}! \\
! \\
!\end{array}$ \\
\hline $\begin{array}{l}\text { JAPAM } \\
\text { IDEMIISU, } 30.3 \\
\text { [11] }\end{array}$ & Hokkeido Refinery & COAL & $\begin{array}{l}\text { COLOMBI } \\
--\operatorname{sun}=-\end{array}$ & W-CERREJON COAL & $\begin{array}{l}5.9 \\
35.0\end{array}$ & 39.3 & $\begin{array}{l}53.1 \\
--65.0\end{array}$ & $\begin{array}{l}1.6 \\
\text { SOLIOS }\end{array}$ & 0.5 & $\begin{array}{l}13,500 \\
9,300\end{array}$ & $!$ \\
\hline
\end{tabular}


APPEADIX C. (CONTIRUED) - PAOE 3 OF 6

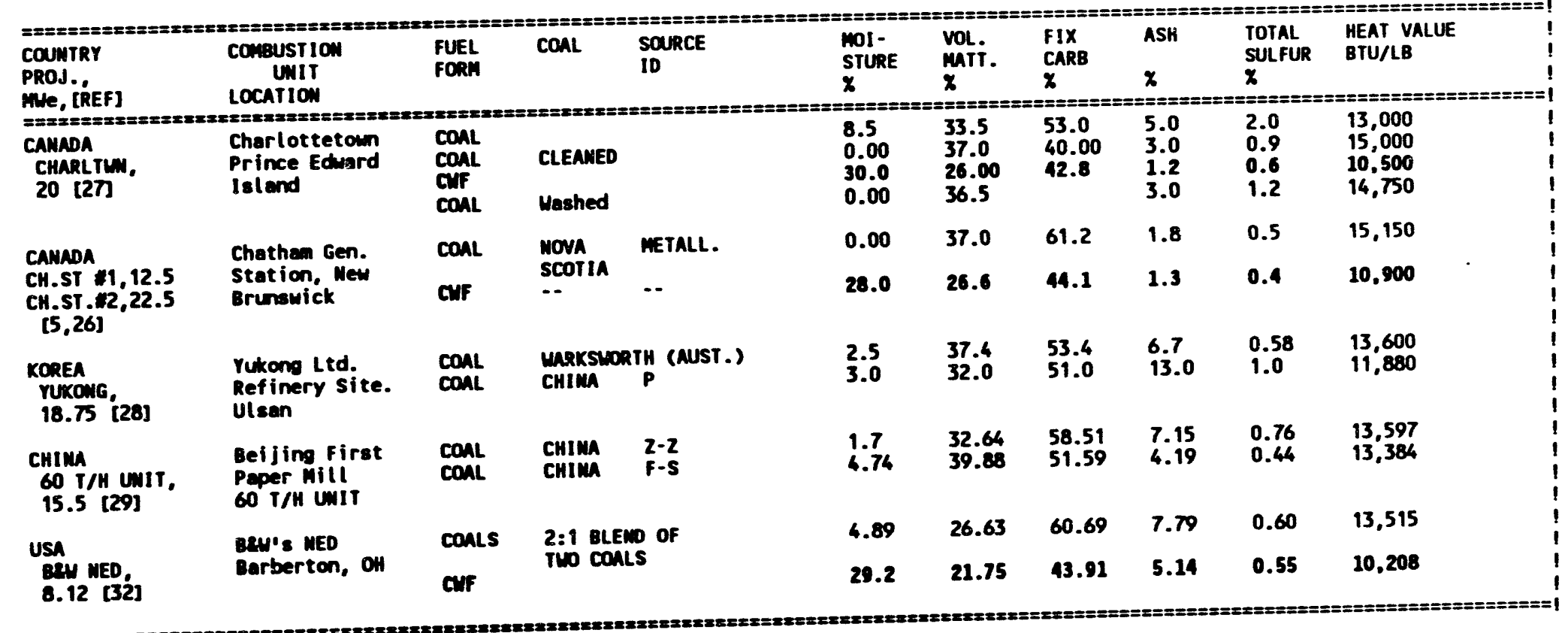


APPEADIX C. (COATIMULD)- PAGE 4 OF 6

\begin{tabular}{|c|c|c|c|c|c|c|c|c|c|}
\hline $\begin{array}{l}\text { COUNTRY } \\
\text { PROJ., } \\
\text { MUe, [REF] } \\
x=x=x=x=x=x=2\end{array}$ & 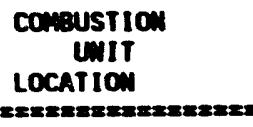 & $\begin{array}{l}\text { FUEL } \\
\text { FORM } \\
\text { maxax }\end{array}$ & 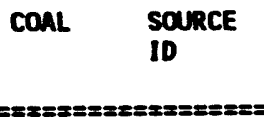 & $\begin{array}{l}\text { Mol- } \\
\text { STURE } \\
x \\
= \pm=== \pm=\end{array}$ & $\begin{array}{l}\text { VOL. } \\
\text { Miti. }\end{array}$ & $\begin{array}{l}\text { fIX } \\
\text { CARB } \\
x \\
= \pm===\end{array}$ & $\begin{array}{l}\text { ASH } \\
x \\
x===\end{array}$ & $\begin{array}{l}\text { TOTAL } \\
\text { SULFUR } \\
x \\
=======\end{array}$ & $\begin{array}{l}\text { MEAT VALUE } \\
\text { BTU/LB } \\
==========8\end{array}$ \\
\hline 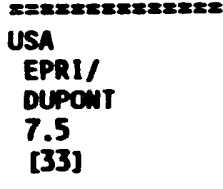 & $\begin{array}{l}\text { Meuphis, TH } \\
\text { DuPont init }\end{array}$ & $\begin{array}{l}\operatorname{conh} \\
\cos \\
\cosh \\
\cos \end{array}$ & $\begin{array}{l}\text { MOUTCOAL (WV)-ARC } \\
\text { ARC } \\
\text { PIITSTON moss BY } \\
\text { CO-AL }\end{array}$ & $\begin{array}{l}0.00 \\
29.7 \\
0.00 \\
24.7\end{array}$ & $\begin{array}{l}32.9 \\
23.1 \\
30.8 \\
23.2\end{array}$ & $\begin{array}{l}62.5 \\
44.0 \\
62.5 \\
47.1\end{array}$ & $\begin{array}{l}4.6 \\
3.2 \\
6.7 \\
5.0\end{array}$ & $\begin{array}{l}0.61 \\
0.43 \\
0.78 \\
0.59\end{array}$ & $\begin{array}{l}14,810 \\
10,410 \\
14,620 \\
11,010\end{array}$ \\
\hline $\begin{array}{l}\text { USA } \\
\text { V. DALE, } \\
7.5[34]\end{array}$ & $\begin{array}{l}\text { Valleydale } \\
\text { Packers Prod. } \\
\text { Plant, Bristol, } \\
\text { VA }\end{array}$ & $\begin{array}{l}\operatorname{con} L \\
\cos \end{array}$ & $\begin{array}{l}\text { VA HIGH Vol BIT } \\
\text { UCC Hydro coal }\end{array}$ & $\begin{array}{l}7.40 \\
37.0\end{array}$ & $\begin{array}{l}30.21 \\
20.55\end{array}$ & $\begin{array}{l}55.36 \\
37.07\end{array}$ & $\begin{array}{l}5.89 \\
4.51\end{array}$ & $\begin{array}{l}1.14 \\
0.87\end{array}$ & 8.689 \\
\hline $\begin{array}{l}\text { SLEDEN } \\
\text { SUINOBYBERG, } \\
6.87[35,36]\end{array}$ & $\begin{array}{l}\text { Sundbybers } \\
\text { Muni. Dist. } \\
\text { Meat ing }\end{array}$ & Cur & $\begin{array}{l}\text { WASHED HIGH-VOL. } \\
\text { U.S. BITU. COAL }\end{array}$ & 30.0 & 23.0 & $44-43$ & $2-3$ & 0.5 & 9.475 \\
\hline $\begin{array}{l}\text { SWEDEN } \\
\text { LUID UTILITY } \\
10 \text { [3T }\end{array}$ & Lund Utility & $\cos L$ & $\begin{array}{l}\text { POLISH STEAM } \\
\text { COAL }\end{array}$ & 9.5 & 28.5 & 51.3 & 11.7 & 0.58 & 12,485 \\
\hline
\end{tabular}


APPEADIX C. (COATIMUED)- PAOE 5 OF 6

\begin{tabular}{|c|c|c|c|c|c|c|c|c|c|}
\hline $\begin{array}{l}\text { COUWTRY } \\
\text { PROJ., } \\
\text { me, [REF] }\end{array}$ & $\begin{array}{l}\text { Combustion } \\
\text { UNIT } \\
\text { LOCATION }\end{array}$ & $\begin{array}{l}\text { FUEL } \\
\text { FORM }\end{array}$ & $\begin{array}{ll}\text { COAL SOURCE } \\
\text { ID }\end{array}$ & $\begin{array}{l}\text { MO1- } \\
\text { STURE } \\
x\end{array}$ & $\begin{array}{l}\text { vol. } \\
\text { Murt. } \\
\text { x }\end{array}$ & $\begin{array}{l}\text { FIX } \\
\text { CARB } \\
X\end{array}$ & $\begin{array}{l}\text { ASH } \\
x\end{array}$ & $\begin{array}{l}\text { TOTAL } \\
\text { SULFUR } \\
\mathbf{x}\end{array}$ & $\begin{array}{l}\text { HEAT VALUE } \\
\text { BTU/LB }\end{array}$ \\
\hline $\begin{array}{l}\text { SWEDEM } \\
\text { COWM: CONTS. } \\
\text { (1) } 10 \text { (2)3.0 } \\
\text { (3) } 2.5 \\
\text { (37.381 }\end{array}$ & $\begin{array}{l}\text { (1) Lund Utility } \\
\text { (2) Foodia AB } \\
\text { (3) SAB WIFE }\end{array}$ & Cur & $\begin{array}{l}\text { POLISH } \\
\text { STEAM COAL: }\end{array}$ & 35.50 & ---60.87 & 7-.- & 3.35 & 0.28 & $\begin{array}{l}8.400 \\
\text { (CUF) }\end{array}$ \\
\hline $\begin{array}{l}\text { CHIMA } \\
20 \mathrm{~T} / \mathrm{H} \text { UNIT } \\
5.5 \\
{[30,31]}\end{array}$ & $\begin{array}{l}20 \text { t/h unit } \\
\text { Beijing II Paper } \\
\text { Plant. }\end{array}$ & $\begin{array}{l}\text { conL } \\
\text { cont }\end{array}$ & $\begin{array}{l}\text { Fushun- Trp. Anal: } \\
\text { Bayi-Trp. Anal: }\end{array}$ & $\begin{array}{l}4.74 \\
1.70\end{array}$ & $\begin{array}{l}39.88 \\
32.64\end{array}$ & $\begin{array}{l}51.19 \\
58.51\end{array}$ & $\begin{array}{l}4.17 \\
7.15\end{array}$ & $\begin{array}{l}0.44 \\
0.76\end{array}$ & $\begin{array}{l}13,389 \\
13,592\end{array}$ \\
\hline $\begin{array}{l}\text { USA } \\
\text { PSU } \\
1.8 \\
{[8,39]}\end{array}$ & $\begin{array}{l}\text { University } \\
\text { Park, PA }\end{array}$ & $\cos L$ & $\begin{array}{l}\text { HIGH-VOLA. } \\
\text { COAL A } \\
\text { LALREMCE } \\
\text { COUWTY,PA }\end{array}$ & 0.00 & 35.2 & 60.5 & 4.3 & 0.9 & 14,000 \\
\hline
\end{tabular}


APPEADIX C. (COMPINUED)- PACE 6 OF 6

\begin{tabular}{|c|c|c|c|c|c|c|c|c|c|c|}
\hline 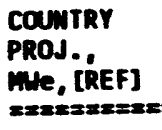 & $\begin{array}{l}\text { comaustion } \\
\text { UnIT } \\
\text { Location }\end{array}$ & $\begin{array}{l}\text { FUEL } \\
\text { FORH }\end{array}$ & conl & $\begin{array}{l}\text { SOURCE } \\
\text { I0 }\end{array}$ & $\begin{array}{l}\text { Mol - } \\
\text { STURE } \\
x \\
=====\end{array}$ & $\begin{array}{l}\text { VOL. } \\
\text { MiT. } \\
x=====\end{array}$ & $\begin{array}{l}\text { FIX } \\
\text { CARB } \\
x \\
=====\end{array}$ & $\begin{array}{l}\text { ASH } \\
x \\
x====\end{array}$ & $\begin{array}{l}\text { TOTAL } \\
\text { SULFUR } \\
x \\
=======\end{array}$ & 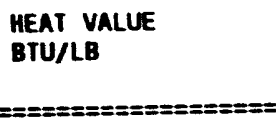 \\
\hline $\begin{array}{l}\text { USA } \\
\text { BAM } \\
\text { BURNER } \\
\text { [61] }\end{array}$ & $\begin{array}{l}\text { Riley Stoker's } \\
\text { Furnace in } \\
\text { Worcester. m }\end{array}$ & $\begin{array}{l}\cos A L \\
\text { Cif }\end{array}$ & $\begin{array}{l}\text { ARC } \\
\text { ARC }\end{array}$ & & $\begin{array}{l}0.00 \\
29.6\end{array}$ & $\begin{array}{l}30.92 \\
23.3\end{array}$ & $\begin{array}{l}62.15 \\
43.1\end{array}$ & $\begin{array}{l}6.93 \\
4.0\end{array}$ & $\begin{array}{l}0.7 \\
0.9\end{array}$ & $\begin{array}{l}14,490 \\
10,278\end{array}$ \\
\hline $\begin{array}{l}\text { USA } \\
\text { ABB/CE } \\
\text { BURNER } \\
\text { [42] }\end{array}$ & $\begin{array}{l}\text { ABB/CE's KDL } \\
\text { facillity in } \\
\text { uindsor, CT }\end{array}$ & $\begin{array}{l}\operatorname{con} \\
\cos \\
\operatorname{con} \\
\operatorname{cof}\end{array}$ & $\begin{array}{l}\text { OXCE } \\
\text { OXCE } \\
\text { ARC } \\
\text { ARC }\end{array}$ & & $\begin{array}{l}0.00 \\
31.4 \\
0.00 \\
28.0\end{array}$ & $\begin{array}{l}33.1 \\
22.7 \\
29.8 \\
21.4\end{array}$ & $\begin{array}{l}60.95 \\
41.8 \\
64.7 \\
46.6\end{array}$ & $\begin{array}{l}6.0 \\
4.1 \\
5.5 \\
4.0\end{array}$ & $\begin{array}{l}0.8 \\
0.5 \\
0.9 \\
0.6\end{array}$ & $\begin{array}{r}14.220 \\
9.750 \\
14.190 \\
10.215\end{array}$ \\
\hline
\end{tabular}


APPENDIX D. FEED MMTEIAT CONDITIONS ND BURWER/ATOMIZER DETAILS ON TAE CONL-WATER FUEL COABUSTIOA DENONBTRATION PROJECTS.-- PAGE 1 OF 6

\begin{tabular}{|c|c|c|c|c|c|c|c|}
\hline 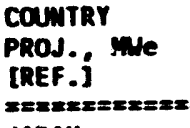 & $\begin{array}{l}\text { CONBUSTION } \\
\text { UWIT LOCATION }\end{array}$ & $\begin{array}{l}\text { Consustion } \\
\operatorname{AIR}_{\text {TEMP, } F}\end{array}$ & $\begin{array}{l}\text { CWF TEMP, } \\
\text { AT BURWER, } \\
\mathbf{F} \\
x=x=x=x=x\end{array}$ & 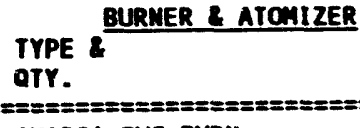 & $\begin{array}{l}\text { ATONIZER } \\
\text { MEDIA \& COND. }\end{array}$ & $\begin{array}{l}\text { BURMER/ } \\
\text { ATOHIZER } \\
\text { MADE BY } \\
==============\end{array}$ & $\begin{array}{l}\text { EROSION } \\
\text { PROTECTION } \\
\text { MATERIAL } \\
==================\end{array}$ \\
\hline $\begin{array}{l}\text { JAPAM } \\
\text { MAKOSO } \\
600 \\
{[16,15]}\end{array}$ & $\begin{array}{l}\text { JOBAN JOINT } \\
\text { POWER CO'S } \\
\text { MAKOSO WO UNIT }\end{array}$ & $\cdots$ & -- & $\begin{array}{l}\text { 'MARC' CWF BURN..' } \\
\text { TILTING TANG.OIL, } \\
\text { \& COAL BURMERS. }\end{array}$ & $\begin{array}{l}\text { INTERMEDIATE } \\
\text { MIXING, STEAM } \\
\text { ATOM. AT } 206 \text { PSI }\end{array}$ & MITSUBISHI & $\begin{array}{l}\text { SILICON CARBIDE } \\
\text { OR TUNGSTEN } \\
\text { CARBIDE }\end{array}$ \\
\hline $\begin{array}{l}\text { USA } \\
\text { BOS. EDI... } \\
135 \\
{[5,16]}\end{array}$ & $\begin{array}{l}\text { MYSTIC STATION } \\
4 \text { AT } \\
\text { BOSTON EDISON }\end{array}$ & 500 & 65 & $\begin{array}{l}\text { TWO COEN ZWN } \\
\text { CWF BURNERS. }\end{array}$ & $\begin{array}{l}\text { COEN ATOMIZERS } \\
\text { AIR ATOMIZED }\end{array}$ & ABB/CE (COEN) & $\begin{array}{l}\text { BOROFUSE } \\
\text { COATED }\end{array}$ \\
\hline $\begin{array}{l}\text { ITALY } \\
\text { S.8ARBARA } \\
\text { I25 } \\
{[17]}\end{array}$ & SANTA BARBARA & $320--446$ & $77--230$ & $\begin{array}{l}\text { BURNER A: ORIGIMAL } \\
\text { BEH DESIGN. EOPD. } \\
\text { UITH SUPPORT GAS. } \\
\text { GURWER B: MOOIFIIED } \\
\text { AIR REGISTER. }\end{array}$ & $\begin{array}{l}\text { (1)INTER MIX ATOA. } \\
\text { (2)Y-JET ATOH } \\
\text { (3) Y-MIXING ATOM } \\
\text { (4) ULTRASONIC } \\
\text { ATOMIZER. }\end{array}$ & $\begin{array}{l}\text { BEH } \\
\text { (AIR \& } \\
\text { STENM } \\
\text { ATOA.) }\end{array}$ & $\begin{array}{l}\text { LOW WEAR RATE } \\
\text { DUE TO SHORT } \\
\text { TEST PERIOD. }\end{array}$ \\
\hline $\begin{array}{l}\text { USA } \\
\text { SCE2G } \\
75 \\
{[5,18]}\end{array}$ & $\begin{array}{l}\text { UROUHART STATIOW } \\
\text { SCERG, BEECH } \\
\text { ISLAMD, SC. }\end{array}$ & -- & AMBIENT & $\begin{array}{l}\text { ABB/CE COEN ATOH. } \\
\text { QTY: } 4\end{array}$ & AIR ATOMIZED & ABB/CE (COEN) & $\begin{array}{l}\text { CERAMIC \& } \\
\text { TUWG. CARBIDE }\end{array}$ \\
\hline
\end{tabular}


APPENDIX D. (CONTINUED): PAGS 2 OF 6

\begin{tabular}{|c|c|c|c|c|c|c|c|}
\hline 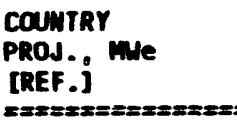 & $\begin{array}{l}\text { COMBUSTION } \\
\text { UNIT LOCATION } \\
=x=2=x=x=x=2 x=x=2 x=\end{array}$ & $\begin{array}{l}\text { Corrastion } \\
\text { AIR } \\
\text { TEIP, F. }\end{array}$ & $\begin{array}{l}\text { CUF TENP. } \\
\text { AT BURMER, } \\
\text { F } \\
== \pm== \pm==E==\end{array}$ & 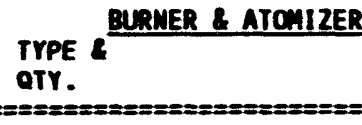 & $\begin{array}{l}\text { ATOMIZER } \\
\text { MEDIA \& COND. } \\
\text { =:==:=:=:==:=:==:=:= }\end{array}$ & 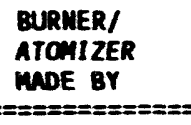 & $\begin{array}{l}\text { EROSION } \\
\text { PROIECTION } \\
\text { MATERIAL } \\
== \pm============0\end{array}$ \\
\hline $\begin{array}{l}\text { JAPAM } \\
\text { MAKOSO } 4 \\
75 \\
{[19]}\end{array}$ & $\begin{array}{l}\text { JOBAN JOINT } \\
\text { POAER CO's } \\
\text { MAKOSO UNIT }\end{array}$ & $500-550$ & $99--106$ & $\begin{array}{l}16 \text { CUF BURNERS } \\
\text { EACH RATED AT } \\
60 \text { MILLIOW BTU/HR }\end{array}$ & $\begin{array}{l}\text { STEAM AT } \\
\text { 150-155 PSI }\end{array}$ & $\begin{array}{l}\text { MITSUBISHI - } \\
\text { DESIGN }\end{array}$ & $\begin{array}{l}\text { EXPECTED BUT } \\
\text { NOT SPECIFIED. } \\
\text { - LON VEAR RATE }\end{array}$ \\
\hline $\begin{array}{l}\text { USA } \\
\text { MERMER, } 60 \\
\text { [20,21] }\end{array}$ & $\begin{array}{l}\text { MERMER STATION } \\
\text { SOUTH MBOY, MJ } \\
\text { CYCLOUE FURRACE }\end{array}$ & $\cdots$ & $\cdots$ & $\begin{array}{l}\text { VARIABLE SPEED } \\
\text { PUMP DRIVE \& } \\
\text { METER SYSTEM. }\end{array}$ & AIR & $\cdots$ & $\begin{array}{l}\text { IMEXPENSIVE CAST - } \\
\text { IRON MOZZLES. }\end{array}$ \\
\hline $\begin{array}{l}\text { ITALY } \\
\text { S. GILLA, } \\
35 \\
{[22-24]}\end{array}$ & $\begin{array}{l}\text { SANTA GILLA } \\
\text { UNIT :2. }\end{array}$ & -- & $\cdots$ & $\begin{array}{l}8 \text { GURERS ON } \\
\text { TWO PLAMES. }\end{array}$ & $\begin{array}{l}Y \text {-MIXIMG ATOHIZER, } \\
\text { AIR OR } \\
\text { STEAM ATONIZED }\end{array}$ & $\cdots$ & $\begin{array}{l}\text { CERAMIC } \\
\text { PROTECTIOM } \\
\text { POSSIBILITY. }\end{array}$ \\
\hline$\underset{\text { MIMEJI, }}{\operatorname{JAPAN}} \mathbf{3 3}$ & $\begin{array}{l}\text { KAMSAI ELEC; CO 's } \\
\text { HIMEJI MO. i } \\
\text { IHI-FU SIMGLE DRUM }\end{array}$ & 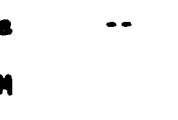 & $\cdots$ & $\begin{array}{l}\text { DUAL-FUEL, INTERMAL } \\
\text { MIXIMG }(3.8 \mathrm{~T} / \mathrm{H}, \\
\text { OTY:8) }\end{array}$ & STEM & IHI & $\begin{array}{l}\text { CERAMIC SLEEVES } \\
\text { IN MEAR-PROUE } \\
\text { PARTS. }\end{array}$ \\
\hline $\begin{array}{l}\text { JAPAN } \\
\text { IDENITSU, } 30.3\end{array}$ & $\begin{array}{l}\text { MOKKAIDO } \\
\text { REFIMERY }\end{array}$ & $\cdots$ & -- & $\cdots$ & $\cdots$ & $\cdots$ & $\begin{array}{l}\text { TUNCSTEN CARBIDE } \\
\text { BURAER WOZZLE }\end{array}$ \\
\hline
\end{tabular}


APPEATIX D. (CONTINUTD): RACS 3 OF 6

\begin{tabular}{|c|c|c|c|c|c|c|c|}
\hline $\begin{array}{l}\text { COUNTRY } \\
\text { PROd.: mie } \\
\text { [REF.j } \\
x=x=x=x=x=x=x\end{array}$ & $\begin{array}{l}\text { COMBUSTIOH } \\
\text { UWIT LOCATION }\end{array}$ & $\begin{array}{l}\text { COmaustion } \\
\text { AIR } \\
\text { TEYP. F. }\end{array}$ & $\begin{array}{l}\text { CWF TEMP. } \\
\text { AT DURMER, } \\
\text { F } \\
\text { Ex=mx=mx=xx= }\end{array}$ & $\begin{array}{l}\text { TYPE \& } \\
\text { QTY. } \\
\text { OTMER \& ATOAIZER } \\
\end{array}$ & 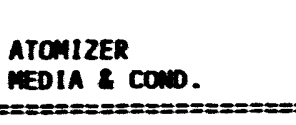 & $\begin{array}{l}\text { BURMER/ } \\
\text { ATOMIZER } \\
\text { MOEE BY } \\
===========\end{array}$ & 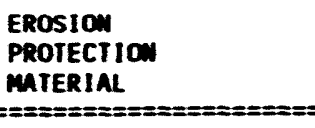 \\
\hline $\begin{array}{l}\text { CAMNDA } \\
\text { CHARLOTTETOM, } \\
20 \\
{[27]}\end{array}$ & $\begin{array}{l}\text { CHARLOTTETOM. } \\
\text { PRIMCE EDMARD, } \\
\text { ISLAND. }\end{array}$ & 450 & 67 & $\begin{array}{l}\text { (1) COEN DURMERS } \\
\text { MEAT INPUT--44 MBTU/ } \\
\text { HR. (2)EMR/MRC } \\
-- \text { (TESTED AT CHATHN) }\end{array}$ & $\begin{array}{l}\text { (1) STENH ATONIZED } \\
\text { (2) STEN OR } \\
\text { AIR ATOA. }\end{array}$ & $\begin{array}{l}\text { (1)COEN CO. } \\
\text { (2) EMR/MRC } \\
\text { DEVELOPED. }\end{array}$ & $\begin{array}{l}\text { (1) CERAMIC PROT. } \\
\text { (2)CERAMIC PROT. }\end{array}$ \\
\hline $\begin{array}{l}\text { CAMADA } \\
\text { (1) ST.\#1, 12.5 } \\
(2) \text { ST. } 12.22 .5 \\
{[5,26]}\end{array}$ & $\begin{array}{l}\text { CHATHAM GEN. } \\
\text { STATIOWS, MEU } \\
\text { BRUNSUICK }\end{array}$ & (1) $\quad \cdots$ & $\begin{array}{l}\text { (1) } 95 \\
\text { (2) } 95\end{array}$ & $\begin{array}{l}\text { (1) FW/FORNEY } \\
\text { OTY:4. } \\
\text { (2) } A B B / C E \text {, OTY:4 }\end{array}$ & $\begin{array}{l}\text { (1) AIR } \\
\text { (2) AIR \& STEM }\end{array}$ & $\begin{array}{l}\text { (1) FOSTER } \\
\text { WHEELER } \\
\text { (2) } A B B / C E\end{array}$ & $\begin{array}{l}\text { (1) vaRIOUS } \\
\text { MATERIALS } \\
\text { (2) CERAMIC \& } \\
\text { TUMG. CARBIDE. }\end{array}$ \\
\hline $\begin{array}{l}\text { KOREA } \\
\text { YUKONG } \\
18.7 \\
{[28]}\end{array}$ & $\begin{array}{l}\text { YUKONG LTO'S } \\
\text { REFIMERY SITE } \\
\text { IN ULSAN }\end{array}$ & $440--451$ & $203-212$ & $\begin{array}{l}\text { FOUR MODIFIED } \\
\text { Bey BURERS. }\end{array}$ & $\begin{array}{l}\text { MODIFIED T-JET } \\
\text { ATOM. STEAM } \\
\text { (110-i14 PSI) }\end{array}$ & $\begin{array}{l}\text { BEN-BOTH } \\
\text { BURNERS } 2 \\
\text { ATOH. }\end{array}$ & $\begin{array}{l}\text { TUNGSIEN } \\
\text { CARBIDE }\end{array}$ \\
\hline $\begin{array}{l}\text { CHIMA } \\
60 \mathrm{~T} / \mathrm{MR} \\
15.5 \\
{[29]}\end{array}$ & $\begin{array}{l}\text { BEIJING FIRST } \\
\text { PAPER MILL'S } \\
60 \mathrm{~T} / H \text { UNIT }\end{array}$ & 302 & 175 & $\begin{array}{l}\text { SIX BURWERS. TANG. } \\
\text { SWIRLIMG REGISTER } \\
\text { USED. }\end{array}$ & $\begin{array}{l}\text { SUPERHEATED STEAM } \\
\text { ATOMIZED. }\end{array}$ & $\begin{array}{l}\text { ZHEJIAMG UWI. } \\
\text { DEVELOPED. }\end{array}$ & $\begin{array}{l}\text { MOZZLES MAD } \\
\text { PROT : TUWG CARBIDE. } \\
\text { AND U-MI-CO ALLOY. }\end{array}$ \\
\hline
\end{tabular}


APPEADIX D. (COATILUED): PROS OF 6

\begin{tabular}{|c|c|c|c|c|c|c|c|}
\hline $\begin{array}{l}\text { COUWTRY } \\
\text { PROA.: inle } \\
\text { tREF.j } \\
x=x=x=x==x=x\end{array}$ & 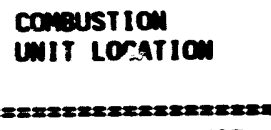 & $\begin{array}{l}\text { Compustion } \\
\text { AIR } \\
\text { TERP. F. }\end{array}$ & $\begin{array}{l}\text { CUF TEWP. } \\
\text { AT BURUER, } \\
\text { F }\end{array}$ & $\begin{array}{l}\text { TYPE \& } \\
\text { QTY. }\end{array}$ & $\begin{array}{l}\text { ATOMIZER } \\
\text { MEDIA \& COMD. }\end{array}$ & $\begin{array}{l}\text { DURNER/ } \\
\text { ATOAIZER } \\
\text { MOE BY } \\
=========\end{array}$ & $\begin{array}{l}\text { EROSION } \\
\text { PROTECTIOU } \\
\text { MATERIAL } \\
================\end{array}$ \\
\hline $\begin{array}{l}\text { USA } \\
\text { MED,8.12 } \\
\text { [32] }\end{array}$ & $\begin{array}{l}\text { BEN'S 'NED 'UNIT } \\
\text { EAReERTOW, OH }\end{array}$ & UP TO 475 & $165-220$ & 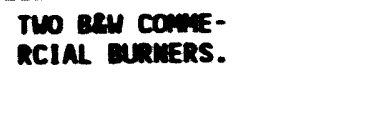 & $\begin{array}{l}\text { MOOIFIED T-JET } \\
\text { AIR (ISO PSIG) } \\
\text { Q STEAH (10OPSIG) }\end{array}$ & Ben & $\begin{array}{l}\text { PROTECTED BY } \\
\text { TUMG. CARBIDE }\end{array}$ \\
\hline $\begin{array}{l}\text { USA } \\
\text { EPRI DOPont } \\
7.5 \\
\text { [33] }\end{array}$ & $\begin{array}{l}\text { oupont co's INIT } \\
\text { III MEIPHIS. TII }\end{array}$ & $300-600$ & 70 & $\begin{array}{l}25 \text { MTU/HR } \\
\text { OURHER TESTED } \\
\text { BY EIM (QTY:3) }\end{array}$ & $\begin{array}{l}\text { BEH T-JET } \\
\text { AIR (150-250 PSI) }\end{array}$ & Bety & $\begin{array}{l}\text { TUMGSTEN } \\
\text { CARBIDE }\end{array}$ \\
\hline $\begin{array}{l}\text { USA } \\
\text { Y.DALE. } 7.5 \\
\text { [36] }\end{array}$ & $\begin{array}{l}\text { VALLEYDALE PACK. } \\
\text { PROD. PLANT } \\
\text { BRISTOL, va }\end{array}$ & $\cdots$ & $\begin{array}{l}\text { MIGHER } \\
\text { THAM } 41\end{array}$ & PK-54 DURMER & $\begin{array}{l}\text { MODIFED DUAL } \\
\text {-FLUID ATOA } \\
\text { (AIR, } 100 \text { PSIG) }\end{array}$ & PEABCOOY & $\begin{array}{l}\text { MARDEEMED STEEL } \\
\text { CONST, W/O } \\
\text { OTHER PROT. }\end{array}$ \\
\hline $\begin{array}{l}\text { SUEDEN } \\
\text { SUDOYRERG } \\
6.87 \\
{[35,36]}\end{array}$ & $\begin{array}{l}\text { SUMDEYEERG } \\
\text { MUII. DIST } \\
\text { MEATIMG PLAMT }\end{array}$ & $\cdots$ & $-\cdot$ & $\begin{array}{l}\text { TWO ABB/CE-DESIEUED } \\
\text { OUNERS, EVOLVED } \\
\text { FROM SUIRL-DESIEN } \\
\text { PAOCRAM. }\end{array}$ & $\begin{array}{l}\text { THIN FLUID Y-JET } \\
\text { ATONIZER INCORPO- } \\
\text { RATING DESIGN } \\
\text { IMPROVERENTS. }\end{array}$ & ABB/CE & $\begin{array}{l}\text { TUNGSTEN } \\
\text { CARBIDE } \\
\text { INSERTS. }\end{array}$ \\
\hline $\begin{array}{l}\text { SIEDEN } \\
\text { LUip. } 10 \\
\text { [BT }\end{array}$ & Lum UTILITY & $\cdots$ & $\cdots$ & $\begin{array}{l}\text { MFO \& ROTARY } \\
\text { CP ELRERS. }\end{array}$ & -- & FLutocareom & $\cdots$ \\
\hline
\end{tabular}


APPEADIX D. (CONHINUED): PACS 5 OF 6

\begin{tabular}{|c|c|c|c|c|c|c|c|}
\hline $\begin{array}{l}\text { COUNTRY } \\
\text { PROJ., mie } \\
\text { IREF.j } \\
x=x=x=x=x=x=2 x=28\end{array}$ & 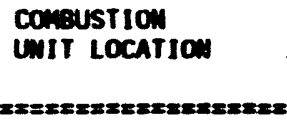 & $\begin{array}{l}\text { COMUUSTIOM } \\
\text { AIR } \\
\text { TEMP, F. }\end{array}$ & $\begin{array}{l}\text { CNF TENP. } \\
\text { AT BURNER, } \\
\text { F } \\
==8=x==8===\end{array}$ & 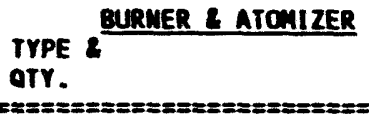 & $\begin{array}{l}\text { ATOMIZER } \\
\text { MEDIA \& COMD. } \\
==:==:======:=\end{array}$ & $\begin{array}{l}\text { BURMER/ } \\
\text { ATOMIZER } \\
\text { MADE BY } \\
\text { =:==:=:=:==:==:==:= }\end{array}$ & $\begin{array}{l}\text { EROSION } \\
\text { PROTECTION } \\
\text { MATERIAL } \\
==================1\end{array}$ \\
\hline $\begin{array}{l}\text { SWEDEN } \\
\text { (1) } 10 \\
(2) 3.0 \\
\text { (3)2.5[37] }\end{array}$ & $\begin{array}{l}\text { (1) LUD UTILITY } \\
\text { (2) FOODIA AB } \\
\text { (3) SAB WIFE UNIT }\end{array}$ & MOUE & -. & $\begin{array}{l}\text { ROTARY CUP } \\
\text { BURNERS IM } \\
\text { ALL CONTRACTS. }\end{array}$ & $\begin{array}{l}\text { (1) } \cdots \\
\text { (2) } \cdots \\
\text { (3) } \cdots\end{array}$ & $\begin{array}{l}\text { FLUIDCARBOW } \\
\text { OF SWEDEN }\end{array}$ & $\begin{array}{ll}\cdots & 1 \\
& 1\end{array}$ \\
\hline $\begin{array}{l}\text { CHIm } \\
20 T / H, 5.5 \\
{[30,31]}\end{array}$ & $\begin{array}{l}\text { BEIJIMG FIRST } \\
\text { MILL'S } 20 \mathrm{~T} / \mathrm{MR} \\
\text { CWIT }\end{array}$ & $\begin{array}{l}\text { PROVISION FOR } \\
\text { AIR PREMEATIMG } \\
\text { DISCUSSED. }\end{array}$ & -- & $\begin{array}{l}\text { NXIAL SUIRLIMG } \\
\text { TYPE REGISTER. }\end{array}$ & $\begin{array}{l}\text { SUIRL ATON. } \\
\text { SATD. STEAM } \\
\text { ATOMIZED }\end{array}$ & $\begin{array}{l}\text { ZHEJIANG } \\
\text { UNIVERSITY } \\
\text { DEVELOPED. }\end{array}$ & $!$ \\
\hline $\begin{array}{l}\text { USA } \\
\text { PSU, } 1.8 \\
{[8,39]}\end{array}$ & $\begin{array}{l}\text { UNIVERSITY } \\
\text { PARK, PA }\end{array}$ & $340-400$ & $\begin{array}{l}\text { UP TO } \\
180\end{array}$ & ONE FABER BURNER. & $\begin{array}{l}\text { OIL GUW/ATOA. } \\
\text { COMP. AIR } \\
\text { ATOMIZED } \\
\text { INTERIML MIX }\end{array}$ & $\begin{array}{l}\text { FABER } \\
\text { (SUBSIDIARY OF } \\
\text { TAMPELLA POWER) }\end{array}$ & MONE \\
\hline $\begin{array}{l}\text { USA } \\
\text { EPRI BURWER } \\
\text { BRU } \\
{[?, .41]}\end{array}$ & $\begin{array}{l}\text { OURWER DEMO. } \\
\text { BY BEH ON } \\
\text { RILEY'S FURWACE } \\
\text { WORCESTER, } M\end{array}$ & $300-600$ & $65-260$ & $\begin{array}{l}\text { ONE BRY FRONT } \\
\text { FIRED EURMER. }\end{array}$ & AIR \& STEAM & Ben & TUNG. CARBIDE \\
\hline
\end{tabular}




\section{APPENDIX D. (CONTIRUED); PAOS 6 OF 6}

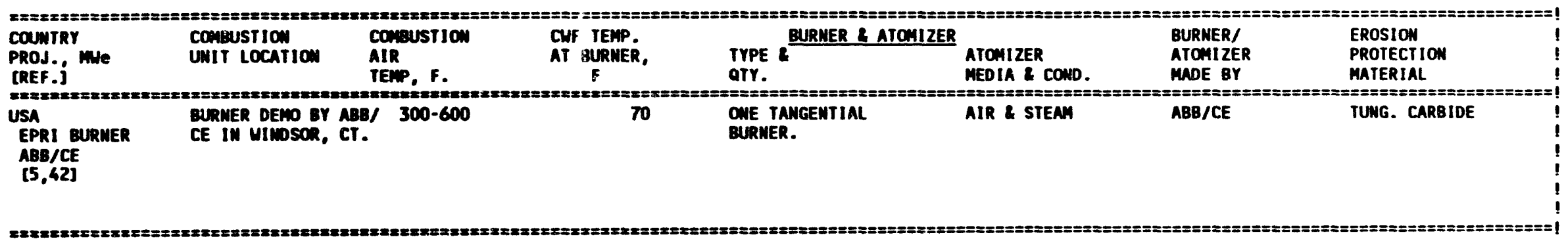




\begin{abstract}
APPENDIX - E
EXPANDED PUBLICATION LIST

COAL-WATER COMBUSTION DEMONSTRATION PROJECTS IN VARIOUS COUNTRIES
\end{abstract}

These are the selected publications related to the CWF combustion projects discussed in this report and on the work planned in the United Kingdom. This list is by country, demonstration project, and the last name of the first author. The references cited in the text of the report are included in this list.

\title{
CANADA
}

CHATHAM AND CHARLOTTETOWN DEMONSTRATION PROJECTS

Cook, D.A.; Kearns, J.D.; Rini, M.J.; and LaFlesh, R.C., "Coal-water-Fuel Firing Experience at Chatham \#2,"Proceedings of the Seventh International Symposium on Coal Slurry Fuels Preparation and Utilization, New Orleans, LA, p. 775, May 21-24, 1985.

Executive Summary of "Coal Water Fuel Combustion Demonstration Charlottetown, Prince Edward Island," a joint project of the Energy Mines and Resources Canada, Maritime Electric Co., Cape Breton Development Corp. and New Brunswick Electric Power Co, Pp. 29, March 1988.

Rankin,D.B.; Burnett, D.J.; Boomhower J.; Whaley H.; and Read, P.J. "CWF Demonstration in a Compact Oil-Designed Utility Boiler, Charlottetown, Prince Edward Island, Canada," Proceedings of the Twelfth International Conference on Slurry Technology, New Orleans, LA, p. 313, March 31-April 3, 1987.

Whaley, H.; Rankin, D.M.; Landry, P.G.; and Covil, I.D., "Utility Boiler Demonstration of Coal-Water Mixture Combustion at Chatham, New Brunswick," Proceedings of the Sixth International Symposium on Coal Slurry Combustion and Technology, Orlando, FL, P. 519, June 25-27, 1984.

Whaley H.; Rankin, D.M.; Read, P.J.; and Covil, I.D. "Coal-Water Fuel Developments in Eastern Canada: The Chatham and Charlottetown Demonstrations and Beyond," Proceedings of the Seventh International Symposium on Coal Slurry Fuels Preparation and Utilization. New Orleans, LA, p. 789, May 21-24, 1985.

\section{CHINA}

Minghu, X.; Deshou L.; Xinyu, C.; Kefa, C.; Chunguang G.; Zhaoqiang W.; and Xiuyue, W. "On the Industrial Tests of Coal-Water Slurry Combustion on $20 \mathrm{t} / \mathrm{h}$ 0il-fired Boiler," Proceedings of the Eighth International Conference on Coal Slurry Fuels Preparation and Utilization, Orlando, $F L$, p. 456, May 27-30, 1986. 
Kefa C.; Minghu X.; Deshou L.; Xinyu, C.; and Qinghang, J. "Progress in the Combustion of Coal Water Slurry- Laboratory Research and Industrial Scale Experiments," Proceedings of the 1985 International Symposium on Mining Technology and Science, China Coal Industry Publishing House, p. 1358, 1987.

Minghu, X.; Deshou L.; Xinyu, C.; Kefa, C.; Zuna W., Fengying C., Zhaoquing W.; and Chunguang $G$. "Experimental Study on Coal-Water Slurry Combustion on 20 $t / h$ Oil-Fired Boiler," Proceedings of the Seventh International Symposium on Coal Slurry Fuels Preparation and Utilization, New Orleans, LA, P. 761, May 21-24, 1985.

Zhaoqiang, W.; Xieyue, W.; and Zhixiong, X., "Coal-Water Fuel Combustion on a 60 $\mathrm{T} / \mathrm{h}$ 0il-fired Industrial Boiler," Proceedings of the Thirteenth International Conference on the Coal Slurry Technologies, Denver, CO, p. $533,1988$.

\section{ITALY}

D'ADDA POWER UNIT

Scachli, A.; Soldadino, G.; Sparacino, M.; Lo Nigro, F., Maccio, G.; Mascalzi, G.; Cassitto, L.; and Variali, G. "CWS Demonstration Project in the 75 MWe Cassano D'Adda Power Unit," Proceedings of the Eighth International Conference on Coal Slurry Fuels Preparation and Utilization, Orlando, FL, p. 728, May 27-30, 1986.

\section{S. BARBARA UNIT}

DeMichele, G.; Graziadio, M.; Ligasachhi, S.; Saccenti, G.; and Salvi, G., "Large Scale CWS Firing Tests at the S. Barbara Power Station," Proceedings of the Fifth International Symposium on Coal Slurry Combustion Technology, Orlando, FL, Volume 2, p. 1053, May 1983.

\section{SANTA GILLA}

Cioni, M.; Ligasachhi, S.; Ruth, L.; and Hargrove, M., "Combustion of Coal-Water Fuels in an 0il-Designed Boiler: Combustion Efficiency," Proceedings of the Fifteenth International Conference on the Coal and siurry Technologies, Clearwater, FL, p. 237, 1990.

DeMichele, G.; Graziadio, M.; Morelli, F.; Andreussi, P.; and Tognotti, L., "Design and Characterization of Large-Scale Atomizers," Proceedings of the Twelfth International Conference on Slurry Technology, New Orleans, LA, $p$. $149,1987$.

DeMichele, G.; Ligasacchi, S.; and Pasini, S., "CWF Firing on an 0il-Designed Utility Boiler," Proceedings of the Twelfth International Conference on Slurry Technology, New Orleans, LA, p. 305, 1987. 
DeMichele, G.; Graziadio, M.; Ligascchi, S.; and Belli, R., "Combustion Characteristics of Coal and Pet Coke Water Mixtures, "Proceedings of the Seventh International Symposium on Coal Slurry Fuels Preparation and Utilization, New Orleans, LA, p. 529, May 21-24, 1985.

Hargrove, M.J.; Kwasnik, A.F.; DeMichele G.; Pasini S.; Trebbi, G., LaRosa P.; Ruth, L.; and Gyorke, D. "Evaluation of Boiler Performance During the CWF Combustion Tests at the Santa-Gilla 35 MWe Oil-Designed Utility Boiler," Proceedings of the Fifteenth International Conference on the Coal and Slurry Technologies, Clearwater, FL, P. 267, 1990.

Quattroni, G.; Mazzanti, A.F.; Smouse, S.; and Hargrove, M. "Evaluation of Coal-Water Fuel Fouling Propensity in Oil-Designed Boilers, "Proceedings of the Fifteenth International Conference on the Coal and Slurry Technologies, Clearwater, FL, p. 253, 1990.

USA See Papers by Combustion Engineering in the USA.

\section{JAPAN}

CWM COMBUSTION ON IDEMITSU KOSAN CO.'S UNIT

Oka, N.; Sato, S.: Kondo, T.; and Simoyama, T., "Demonstration Test of Low Ash CWM Combustion in a $110 \mathrm{t} / \mathrm{h}$ 0il Designed Boiler, " Proceedings of the Sixteenth International Conference on Coal and Slurry Technologies, Clearwater, FL, p. 575, April 22-25, 1991.

CWM COMBUSTION ON NAKOSO UNITS \#4 and *8 BY FUYO GROUP CONSORTIUM

Kaneko, S.; Takatsuka, K.; Imamoto, T.; Gengo, T.; Sakai, M., and Tokuda, K., "Development and Utilization Of Large Capacity Burner," Proceedings of the Eighth International Conference on Coal Siurry Fuels Preparation and Utilization, Orlando, FL, p. 757, May 27-30, 1986.

Kiga, T.; Saitoh, H.; Miyamae, S.; Takahashi, K.; and Kataoka, T., "Combustion Technology of Coal Water Mixtures," Proceedings of the Seventh International Symposium on Coal Slurry Fuels Preparation and Utilization, New Orleans, LA, p. 631, May 21-24, 1985.

Kuroda, H.; Masai,T.; Takahashi, Y.; and Watanabe, S., "Combustion of Coal-Water Slurry in a Multiple-Burner Furnace," Proceedings of the Fifth International Symposium on Coal Slurry Combustion and Technology, Tampa, FL, Volume 1, p. 502, 1983.

Miyamoto, S.; Makino, K.; and Saitoh, H., "Operational Experiences with CWM on 33 MW Himeji No. 1 Boiler of the Kansai Electric Power Co., Inc.," Proceedings of the Thirteenth International Conference on Coal Slurry Technology, Denver, CO, p. 521, April 12-15, 1988.

Shirato, R.; Abe, K.; Nitta K.; and Kaneko, S., "A Plan of Partial CWM Introduction to Nakoso No. 8 Boiler (600 MW) with $200 \mathrm{MBtu} / \mathrm{h}$ CWM Burner," 
Proceedings of the Thirteenth International Conference on Coal Slurry Teciñology, Denver, C0, p. 541, April 12-15, 1988.

Shirato; R.; Abe, K.; Takahashi, T.; Kaneko, S.; Funatsu, H.; Shoji, K.; Kawano, K.; and Shimpo, I., "Coal Water Mixture Demonstration Test at Nakoso," Eighth International Symposium on Coal Slurry Fuels Preparation and Utilization, Orlando, F.L, P. 738, 1986.

Shirato, R.; Sakashita, T.; Yakuki, M.; Sakayori, T.; Hironaka, H.; Nitta K.; Kaneko, S.; Sakai, M.; and Imamoto, T., "Operation Test Results with $200 \mathrm{MBtu} / \mathrm{h}$ CWM Burner at Nakoso No. 8 Unit (600 MW)," Proceedings of the Twelfth International Conference on Slurry Technology, Clearwater, $F L, p$. $419,1987$.

Tani, K.; Muto, T.; Kusunoki, K.; Abe, K.; Nitta, K.; Nakayama, T.; Kaneko, S.; and Imamoto, T.. "Commercial Operation Results of a Partial CWM Introduction at Nakoso No. 8 Boiler $(600 \mathrm{MW}), "$ Proceedings of the Fifteenth International Conference on the Coal and Slurry Technologies, Clearwater, FL, p. 1, 1989.

KOREA

Kim T.C. and Kim, S. "Combustion Test Results of Coal-Water-Fuel into Yukong's Modified Boiler on a Commercial Basis Boiler at Yukong," Proceedings of the Thirteenth International Conference on Coal Slurry Technology, Denver, CO, p. 507, April 12-15, 1988.

SWEDEN

SUNDBYBERG DISTRICT HEATING UNIT OF SUNDBYBERG MUNICIPALITY IN SWEDEN

Astrand L. and Rey, L.H., "CWM Demonstration at Sundbyberg," Sixth International Symposium on Coal Slurry Combustion and Technology, Orlando, FL, p. 541, June 25-27, 1984.

Carlsson, S.A., "The Sundbyberg Coal-Water Fuel Fired Boiler-Experience Gained Between the 6th and 7 th International Symposium on Coal Slurry Fuels," Proceedings of the Seventh International Symposium on Coal slurry Fuels Preparation and Utilization, New Orleans, LA, P. 751, May 21-24, 1985.

Eckmann, C.E. and Carlsson, S.A., "NYCO AB Ar Vika CWM Production Plant Upgrade, "Proceedings of the Twelfth International Conference on Slurry Technology, Clearwater, FL, p. 387, 1987.

Smith, D.A.; Laflesh, R.C.; and Sintorn, H., "Review of Sundbyberg CWM Firing in a Wall Fired Industrial Boiler," Proceedings of the American Power Conference, Published by Illinois Institute of Technology, Chicago. IL, p. 783, 1984. 
Stigsson, Lars L., "Fluidcarbon Fuel Production and Utilization in Sweden," Proceedings of the Seventh International Symposium on Coal slurry Fuels Preparation and Utilization, New Orleans, LA, p. 951, May 21-24, 1985.

COMMERCIAL CONTRACTS OF SVENSKA FLUIDCARBON

Linder, G. and Rorgren, L., "Startup and Operating Experience of Three Commercial CWM Contracts in Sweden," Eighth International Symposium on Coal Slurry Fuels Preparation and Utilization, Orlando, FL, P. 933, May $27-30,1986$.

\section{UNITED KINGDOM}

Selected papers by NEI on the burner/atomizer development, and the plans for further CWF combustion work at Foster Wheeler and Babcock Power.

Allen, J.W.; Rennie, A.G. and Welbourne, M.C., "Atomization of Coal Water Mixtures," Proceedings of the Seventh International Symposium on Coal Slurry Fuels Preparation and Utilization, New Orleans, LA, p. 392, May 21-24, 1985.

Atkins, E., "Status Report on Coal Fuel," Sixth International Symposium on Coal Slurry Combustion and Technology, Orlando, FL, p. 557, June 25-27, 1984.

Anjum, A. and Winnard, S., "Conversion of a $10 \mathrm{MW} \mathrm{0il-Fired} \mathrm{Boiler} \mathrm{to} \mathrm{CWM}$ Firing," Proceedings of the Third European Conference, Malmo, Sweden, I. Chem E. Symposium Series No. 107, p. 259, 1987.

\section{USA}

ABB/COMBUSTION ENGINEERING (CE)

Canada: See work by CE for the Chatham $\$ 2$ Demonstration Project.

Hargrove, M.J.; Levasseur, A.A.; and Chow, 0.K. " "Combustion Cl.uracterization of Coal-Water Mixtures," Proceedings of the Sixth International Symposium on Coal Slurry Combustion and Technology, Orlando, FL, p. 127, June 25-27, 1984.

Hargrove, M; Levasseur, A.A.; Miemiec, L.S.; Grifith, B.F.; and Chow, 0.K., "Performance Characteristics of Coal-Water Fuels and their Impact on Boiler Operation," Proceedings of the Seventh International Symposium on Coal Slurry Fuels Preparation and Utilization, New Orleans, LA, p. 855, May 21-24, 1985.

LaFlesh, R.C.; Rini, M.J.; Lachowicz, Y.V.; and Levasseur, A.A., "Comparison of the Performance of a Cross-section of Commercial CWF Burners," Proceedings 
of the Seventh International Symposium on Coal Slurry Fuels Preparation and Utilization, New Orleans, LA, P. 596, May 21-24, 1985.

Rini, M.J.; Donais, R.E.; and Marion, J.L., "Commercial CWF Burner Demonstration at Conbustion Engineering," Proceedings of the Eighth International Conference on Coal Slurry Fuels Preparation and Utilization, Orlando, FL, p. 696, May 27-30, 1986.

Rini, M.J.; Marion, J.L.; Lachowicz, Y.V., "Combustion of the Combustion Engineering $100 \mathrm{MBtu} / \mathrm{h}$ Burner for Coal-Water Slurries," Electric Power Research Institute, Final Report, Report No. CS-4987, January 1987.

Smith, D.A.; Laflesh, R.C. and Sintorn H., (1984) "Review of Sundbyberg CWM Firing in a Wall Fired Industrial Boiler," Proceedings of the American Power Conference, Published by Illinois Institute of Technology, Chicago, IL, p. 783,1984 .

BABCOCK \& WILCOX (B\&W)

Demonstration on the B\&W NED unit at Barberton, $\mathrm{OH}$ and the Burner Demonstration Project:

Carlson, R.V.; Wilkinson, J.M.; Cartwright, R.A.; and Muckley J.J., "CWF Firing of an Industrial Boiler on a Commercial Basis," Proceedings of the Eighth International Conference on Coal Slurry Fuels Preparation and Utilization, Orlando, FL, p. 910, May 27-30, 1986.

Farthing, G.A. and Markert, D.H., "Demonstration of B\&W 100-MBtu/h Burner for Coal-Water Slurry," Electric Power Research Institute, Final Report, Report No. CS-4809, September 1986.

Rodgers, L.W. and Eckhart, C.F., "Application of Coal-water Slurry Cyclone Combustion for Industrial 0 il/Gas Retrofits," Proceedings of the Thirteenth International Conference on Coal Slurry Technology, Denver, CO, p. 17, April 12-15, 1988.

Warchol J.J.; Farthing, G.A.; and Markert, D.H., "Commercial Coal-water-Fuel Burner Demonstration," Proceedings of the Eighth International Conference on Coal Slurry Fuels Preparation and Utilization, Orlando, FL, p. 706, May $27-30,1986$.

BOSTON EDISON

Faulkner A.R.; Schmid, M.R.; and O'Connor, H.W., "Coal-Water Slurry Barge Delivery to Boston Edison Mystic 4 for a Demonstration Test Burn," Proceedings of the Seventh International Symposium on Coal Slurry Fuels Preparation and Utilization, New Orleans, LA, P. 1047, May 21-24, 1985.

Faulkner, A.R., "CWM Large Burner Development Tests and Demonstrations in the United States and Canada -- 1983-1986," Proceedings of the Seventh 
International Symposium on Coal Slurry Fuels Preparation and Utilization, New Orleans, LA, p. 717, May 21-24, 1986.

EPRI/DUPONT

Furman, R.C., "EPRI Coal-Water Slurry Demonstration Using CO-AL," Proceedings of the Sixth International Symposium on Coal Slurry Combustion and Technology, Orlando, FL, p. 548, June 25-27, 1984.

Perkins, R.P.; Manfred R.K.; and Taylor, B.E., "EPRI Industrial Coai-Water Siurry Demonstration," Proceedings of the Sixth International Symposium on Coal Slurry Combustion and Technology, Orlando, FL, p. 481, June 25-2.7, 1984.

Perkins, R.P. "Coal-Water-Slurry Test in an Industrial Boiler," Electric Power Research Institute Final Report CS-4268, September 1985.

Perkins, R.P. and Manfred, R.K., "Coal Slurry Development Program," Chemical Engineering Progress, Vol. 81, No. 5, p 69, May 1985.

Jersey Central Power and Light \& other Companies:

Anon, Coal Age, p. 17 Dec 1961.

Clancey, J.T., "The Combustion of Coal-Water Slurry Comercial Demonstration at the E.H. Werner Generating Station (October - November 1961)," Consolidation Coal Company, Internal Report No. 2, Project 140-F, March $27,1962$.

Kelcec, G.; 0livadoti, P.P.: and Duzy, A.F., "Coal Slurry Firing at the Werner Station," ASME Paper No. 62-PWR-3, Presented at the AIEE-ASME Joint Power Conference, Baitimore, MD, Sept 24-26, 1962.

Thompson, T.L., "From Reynolds to Wasp- Development of an Industry," Proceedings of the Sixth International Conference on Slurry Transportation, Las Vegas, NV, March 24-27, pp. 23-40, 1981.

Massachusetts Institute of Technology (MIT)

Toqan, M.A.; Srinivasachar, S.; Paloposki, T.; Loehoden, D.; Sayre, A.; and Beer, J.M., "Effects of Coal Fineness, Volatile, and Mineral Matter Content on Carbon Burnout and Fly Ash in Coal Water Fuel Flames," Proceedings of the Twelfth International Conference on Slurry Technology, New Orleans, LA, p. 31, March 31-April 3, 1987. 
PENNSYLVANIA STATE UNIVERSITY (PSU)

Miller, B.G. "Coal-Water Slurry Fuel Utilization in Utility and Industrial Boilers," Chemical Engineering Progress, Vol. 85, No. 3, p. 29, March 1989.

Miller, B.G.; Wincek R,T.; Scaroni, A.W.; Kinnemam W.P.; Jenkins, R.G., "Combustion of CWSF in a $1000 \mathrm{lb} / \mathrm{h}$ Steam Water-Tube Boiler," Proceedings of the Thirteenth International Conference on Coal Slurry Technology, Denver, CO, p. 119, April 12-15, 1988.

Miller, B.G. and Scaroni, A.W., "The Pennsylvania State University's Superclean Coal-Water Slurry Demonstration Program," Proceedings of the Fifteenth International Conference on the Coal and Slurry Technologies, Clearwater, FL, p. 223, 1990.

Miller, B.G. and Scaroni, A.W., "Penn State's Superclean Coal-Water Slurry Demonstration Project," Proceedings of the Seventeenth International Conference on Coal Utilization and Slurry Technologies, Clearwater, FL, $P$. 341, April 28-May 1, 1992.

Ramachandra, P.; Scaroni, A.W.; and Jenkins, R.G., "Status of Commercially Available CWSF Burners and Atomizers in the U.S.," Proceedings of the Twelfth International Conference on Slurry Technology, New Orleans, LA, p. 107, March 31-April 3, 1987.

Ramachandran, P.; Scaroni, A.W.; and Jenkins, R.G., "Commercial Coal Water Slurry Fuel Burners and Atomizers," Proceedings of the Third European Conference, Malmo, Sweden, I. Chem E. Symposium Series No. 107, p 219, 1987.

Kinneman, W.P.; Wincek, R.T.; Miller, B.G.; Scaroni, A.W.; and Jenkins, R.G., "The Conversion of $1000 \mathrm{lb} / \mathrm{hr}$ Steam Boiler to Fire Coal Water Slurry Fuel Proceedings of the Thirteenth International Conference on the Coal Slurry Technology, Denver, CO, p. 725, April 1988.

Walsh, P. "Calculation of Carbon Conversion During Combustion of Coal-Water Fuel in Industrial Boilers," Proceedings of the Fifteenth International Conference on the Coal Slurry Technologies, Clearwater, FL, p. 519, April 25-26, 1990.

Walsh, P.M.; Xie, J.; Elston, J.T.; Miller, B.G.; and Scaroni, A.W., "Erosion of Carbon Steel and Deposition of Particles under the Influence of High Velocity Jet Containing Fly Ash from Coal-Water Slurry Combustion," Seventeenth International Conference on Coal \& Slurry Technologies, Clearwater, FL, p. 561, April 28-May 1, 1992.

\section{SOUTH CAROLINA ELECTRIC \& GAS}

Faulkner, A.R. "CWM Large Burner Development Tests and Demonstrations in the United States and Canada -- 1983-1986," Proceedings of the Seventh 
International Symposium on Coal Slurry Fuels Preparation and Utilization, New Orleans, LA, p. 717, May 21-24, 1986.

Schaefer, C.F. and Faulkner, B.P. "Demonstration of Coal-Water-Mixture Fuel Production and Burning of Utility and Industrial Applications," Presented at the Joint ASME/IEEE Power Generation Conference, Milwaukee, WI, October 20-24, 1985 (ASME 85-JPGC-Fu-3).

CWF DEMONSTRATION ON VALLEYDALE PACKAGE CO.'S UNIT

Wagner, J.; Sommer, T.M.; Taylor, B.E.; and Johnson, S.A. "Coal-Water Mixture Firing in an Industrial Package Boiler - A User's Perspective," Proceedings of the Seventh International Symposium on Coal Slurry Fuels Preparation and Utilization, New Orleans, LA, p. 734, May 21-24, 1985.

\section{CWF COMBUSTION PROJECT REVIEWS AND MISCELLANEOUS}

Bienstock, D. and Foo, O.K. "History and Development of Coal-Liquid Mixtures," Proceedings of the First European Conference on Coal-Liquid Mixtures held 5-6 October, 1983, Institution of Chemical Engineers Symposium Series No. 83. pp. 1-53, 1983.

Fauikner, A.R. "CWM Large Burner Development Tests and Demonstrations in the United States and Canada -- 1983-1986," Proceedings of the Seventh International Symposium on Coal Slurry Fuels Preparation and Utilization, New Orleans, LA, p. 717, May 21-24, 1986.

Glenn, R.D. "Coal Slurry Application and Technology," Electric Power Research Institute Final Report, Number G-7209, August, 1991.

Henderson, C.B.; Scheffe, R.S.; and McHale, E.T., "The Development of Coal-Water Slurries as Boiler Fuel," Fourth Annual Coal Utilization Conference, Houston, TX, p. 251, November 1981.

Kemeny, P. "Conversion of Zhaibei Power Plant Units 15 and 16 From 0il to Coal or Coal-water Fuel Firing Furnace and Boiler Performance Analysis," Proceedings of the Thirteenth International Conference on Coal Slurry Technology, Denver, CO, p. 555, April 12-15, 1988.

Makansi, J. "Coal-Water Fuels," Power, Vol. 129, No. 7, p. 17, July 1985.

Marnel1, Paul "Direct Firing of Coal-Water Suspensions State-of-the-Art Review, " Proceedings of the 3rd International Coal Utilization Exhibition and Conference Houston, TX, p. 486, Nov 18-20, 1980.

Miller, B.G. "Coal-Water Slurry Fuel Utilization in Utility and Industrial Boilers," Chemical Engineering Progress, Vol. 89, No. 3, p. 29, March 1989. 
Miller, B.G. and Scaroni, A.W. "The Pennsylvania State University's Superclean Coal-Water Slurry Demonstration Program," Proceedings of the Fifteenth International Conference on the Coal and Slurry Technologies, Clearwater, FL, p. 223, 1990.

\section{USSR}

BELOVO-NOVOSIBIRSK PIPELINE PROJECT

Ercolani, D.; Minnetti, G.; Belykh, B.N.; Kagan, Y.M.; Kondratiev, A.S.; Khodakov, G.S.; Korochkin, G.K.; and Stolyarov, N.A., "The Try-Out of Coal-Water Suspension Preparation, Transportation, and Combustion Technology on Belovo to Novosibirsk Coal Pipeline," Proceedings of the Sixteenth International conference on Coal \& Slurry Technologies, Clear Water, FL, p. 1, April 22-25, 1991. 

